University of Nebraska - Lincoln

DigitalCommons@University of Nebraska - Lincoln

Publications from USDA-ARS / UNL Faculty

U.S. Department of Agriculture: Agricultural

Research Service, Lincoln, Nebraska

2010

\title{
Classical biological control for the protection of natural ecosystems
}

\author{
R.G. Van Driesche \\ University of Massachusetts, vandries@nre.umass.edu \\ R I. Carruthers \\ USDA-ARS, ray.carruthers@ars.usda.gov \\ T. Center \\ USDA-ARS \\ M.S. Hoddle \\ University of California \\ J. Hough-Goldstein \\ University of Delaware \\ Follow this and additional works at: https://digitalcommons.unl.edu/usdaarsfacpub

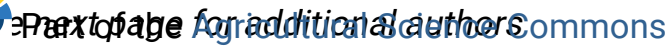

Van Driesche, R.G.; Carruthers, R I.; Center, T.; Hoddle, M.S.; Hough-Goldstein, J.; Morin, L.; Smith, L.; Wagner, D.L.; Blossey, B.; Brancatini, V.; Casagrande, R.; Causton, C.E.; Coetzee, J.A.; Cuda, J.; Ding, J.; Fowler, S.V.; Frank, J. H.; Fuester, R.; Goolsby, J.; Grodowitz, M.; Heard, T.A.; Hill, M.P.; Hoffmann, J.H.; Huber, J.; Julien, M.; Kairo, M.T.K.; Kenis, M.; Mason, P.; Medal, J.; Messing, R.; Miller, R.; Moore, A.; Neuenschwander, P.; Newman, R.; Norambuena, H.; Palmer, W.A.; Pemberton, R.; Perez-Panduro, A.; Pratt, P.D.; Rayamajhi, M.; Salom, S.; Sands, D.; Schooler, S.; Schwarzländer, M.; Sheppard, A.; Shaw, R.; Tipping, P.W.; and van Klinken, R.D., "Classical biological control for the protection of natural ecosystems" (2010). Publications from USDA-ARS / UNL Faculty. 883.

https://digitalcommons.unl.edu/usdaarsfacpub/883

This Article is brought to you for free and open access by the U.S. Department of Agriculture: Agricultural Research Service, Lincoln, Nebraska at DigitalCommons@University of Nebraska - Lincoln. It has been accepted for inclusion in Publications from USDA-ARS / UNL Faculty by an authorized administrator of DigitalCommons@University of Nebraska - Lincoln. 


\section{Authors}

R.G. Van Driesche, R I. Carruthers, T. Center, M.S. Hoddle, J. Hough-Goldstein, L. Morin, L. Smith, D.L. Wagner, B. Blossey, V. Brancatini, R. Casagrande, C.E. Causton, J.A. Coetzee, J. Cuda, J. Ding, S.V. Fowler, J. H. Frank, R. Fuester, J. Goolsby, M. Grodowitz, T.A. Heard, M.P. Hill, J.H. Hoffmann, J. Huber, M. Julien, M.T.K. Kairo, M. Kenis, P. Mason, J. Medal, R. Messing, R. Miller, A. Moore, P. Neuenschwander, R.

Newman, H. Norambuena, W.A. Palmer, R. Pemberton, A. Perez-Panduro, P.D. Pratt, M. Rayamajhi, S.

Salom, D. Sands, S. Schooler, M. Schwarzländer, A. Sheppard, R. Shaw, P.W. Tipping, and R.D. van Klinken 
Review

\title{
Classical biological control for the protection of natural ecosystems is
}

\author{
R.G. Van Driesche ${ }^{\mathrm{a}, *, 1}$, R.I. Carruthers ${ }^{\mathrm{b}, 1}$, T. Center ${ }^{\mathrm{c}, 1}$, M.S. Hoddle ${ }^{\mathrm{d}, 1}$, J. Hough-Goldstein ${ }^{\mathrm{e}, 1}$, L. Morin ${ }^{\mathrm{f}, 1}$, \\ L. Smith $^{\text {b,1 }}{ }^{\text {, D.L. Wagner }}{ }^{\text {g, } 1}{ }^{\text {, B. Blossey }}{ }^{\text {h }}$, V. Brancatini ${ }^{i}$, R. Casagrande ${ }^{\text {j }}$, C.E. Causton ${ }^{\mathrm{k}}$, J.A. Coetzee ${ }^{\mathrm{l}}$, J. Cuda ${ }^{\mathrm{m}}$, \\ J. Ding $^{\mathrm{n}}$, S.V. Fowler ${ }^{\mathrm{o}}$, J.H. Frank ${ }^{\mathrm{m}}$, R. Fuester ${ }^{\mathrm{p}}$, J. Goolsby ${ }^{\mathrm{q}}$, M. Grodowitz ${ }^{\mathrm{r}}$, T.A. Heard ${ }^{\mathrm{i}}$, M.P. Hill ${ }^{1}$, \\ J.H. Hoffmann ${ }^{\mathrm{s}}$, J. Huber ${ }^{\mathrm{t}}$, M. Julien ${ }^{\mathrm{i}}$, M.T.K. Kairo ${ }^{\mathrm{u}}$, M. Kenis ${ }^{\mathrm{v}}$, P. Mason ${ }^{\mathrm{w}}$, J. Medal ${ }^{\mathrm{m}}$, R. Messing ${ }^{\mathrm{x}}$, \\ R. Miller ${ }^{\mathrm{y}}$, A. Moore ${ }^{\mathrm{y}}$, P. Neuenschwander ${ }^{\mathrm{z}}$, R. Newman ${ }^{\mathrm{aa}}$, H. Norambuena ${ }^{\mathrm{ab}}$, W.A. Palmer ${ }^{\mathrm{ac}}$, \\ R. Pemberton ${ }^{\text {c }}$, A. Perez Panduro ad, P.D. Pratt ${ }^{c}$, M. Rayamajhi ${ }^{c}$, S. Salom ${ }^{\text {ae }}$, D. Sands ${ }^{i}$, S. Schooler $^{\mathrm{i}}$, \\ M. Schwarzländer ${ }^{\text {ag }}$, A. Sheppard ${ }^{\text {f }}$, R. Shaw ${ }^{\text {af }}$, P.W. Tipping ${ }^{c}$, R.D. van Klinken ${ }^{i}$
}

a PSIS/Entomology, University of Massachusetts, Fernald Hall, Amherst, MA 01003, USA

${ }^{\mathrm{b}}$ USDA-ARS, Exotic and Invasive Weeds Research Unit, Albany, CA 94710, USA

c Invasive Plant Research Laboratory, ARS, USDA, 3225 College Avenue, Fort Lauderdale, FL 33314, USA

${ }^{\mathrm{d}}$ Department of Entomology, University of California, Riverside, CA 92521, USA

e Entomology \& Wildlife Ecology, University of Delaware, Newark, DE 19716, USA

${ }^{\mathrm{f}}$ CSIRO Entomology, G.P.O. Box 1700, Canberra, ACT 2601, Australia

${ }^{\mathrm{g}}$ Center for Conservation and Biodiversity, University of Connecticut, Storrs, CT 06269-3043, USA

${ }^{\mathrm{h}}$ Department of Natural Resources, Fernow Hall, Cornell University, Ithaca, NY 14853, USA

i CSIRO Entomology, 120 Meiers Road, Indooroopilly, Qld 4068, Australia

${ }^{\mathrm{j}}$ Department of Plant Sciences, University of Rhode Island, Kingston, RI 02881, USA

${ }^{\mathrm{k}}$ Fundación Charles Darwin, Puerto Ayora, Santa Cruz, Galapagos Islands, Ecuador

${ }^{1}$ Department of Zoology and Entomology, Rhodes University, P.O. Box 94, Grahamstown 6140, South Africa

${ }^{m}$ Department of Entomology E Nematology, University of Florida, Gainesville, FL 32611-0620, USA

${ }^{\mathrm{n}}$ Invasion Ecology and Biocontrol Lab, Wuhan Botanical Garden/Institute, Chinese Academy of Sciences, Moshan, Wuhan, Hubei Province 430074, China

${ }^{\circ}$ Landcare Research, P.O. Box 40, Lincoln 7640, New Zealand

${ }^{\mathrm{P}}$ USDA-ARS, Beneficial Insects Introduction Res., 501 S. Chapel St., Newark, DE 19713, USA

${ }^{\mathrm{q}}$ USDA-ARS, Beneficial Insects Res. Unit, 2413 E. Hwy. 83, Weslaco, TX 78596, USA

${ }^{\mathrm{r}}$ US Army Engineer Research and Development Center, Vicksburg, MS 39180, USA

${ }^{s}$ Zoology Department, University of Cape Town, Rondebosch 7700, South Africa

${ }^{\mathrm{t}}$ Natural Resources Canada, c/o AAFC, K.W. Neatby Building, 960 Carling Avenue, Ottawa, Ont., Canada K1A 0C6

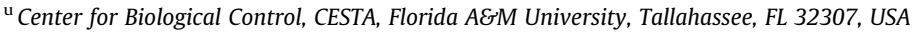

${ }^{\vee}$ CABI Europe-Switzerland, 1, Rue des Grillons, 2800 Delémont, Switzerland

${ }^{\mathrm{w}}$ Agriculture and Agri-Food Canada, Research Centre, K.W. Neatby Building, 960 Carling Avenue, Ottawa, Ont., Canada K1A 0C6

${ }^{x}$ University of Hawaii at Manoa, Kauai Agricultural Research Center, 7370 Kuamoo Road, Kapaa, HI 96746, USA

${ }^{\mathrm{y}}$ Western Pacific Tropical Research Center, University of Guam, Mangilao, GU, USA

${ }^{\mathrm{z}}$ International Institute of Tropical Agriculture, IITA-Benin 08 BP 0932 Cotonou, Benin

${ }^{a}$ Fisheries, Wildlife, and Conservation Biology, University of Minnesota, St. Paul, MN 55108, USA

ab Instituto de Investigaciones Agropecuarias, INIA Carillanca, Camino, Cajón-Vilcún, Km 10, Casilla 58-D, Temuco, Chile

ac Biosecurity Queensland, Department of Employment, Economic Development E Innovation, Alan Fletcher Research Station, P.0. Box 36, Sherwood, Qld 4075, Australia

ad Colegio de Postgraduados, Carr. México - Texcoco Km 36.5, 56230 Montecillo, Edo de México, Mexico

ae Department of Entomology, Virginia Tech, Blacksburg, VA 24061-0319, USA

${ }^{\text {af }}$ CABI E-UK, Bakeham Lane, Egham, Surrey TW20 9TY, England, UK

${ }^{\text {ag }}$ Department of Plant, Soil and Entomological Sciences, University of Idaho, Moscow, ID 83844, USA

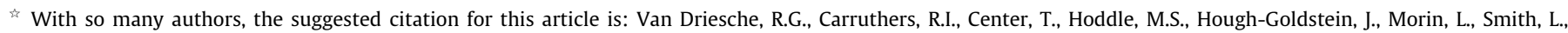
Wagner, D.L., et al., 2010. Classical biological control for the protection of natural ecosystems. Biological Control Supplement 1, S2-S33.

* Corresponding author.

E-mail address: vandries@nre.umass.edu (R.G. Van Driesche).

1 These authors developed sections, with assistance from additional authors who follow.
} 


\section{A R T I C L E I N F O}

Article history:

Received 9 November 2009

Accepted 8 March 2010

Available online 12 March 2010

\section{Keywords:}

Invasive species

Ecosystem function

Insect pests

Invasive plants

Ecological restoration

Biological control

Natural ecosystems

\begin{abstract}
A B S T R A C T
Of the 70 cases of classical biological control for the protection of nature found in our review, there were fewer projects against insect targets (21) than against invasive plants (49), in part, because many insect biological control projects were carried out against agricultural pests, while nearly all projects against plants targeted invasive plants in natural ecosystems. Of 21 insect projects, 81\% (17) provided benefits to protection of biodiversity, while $48 \%$ (10) protected products harvested from natural systems, and $5 \%$ (1) preserved ecosystem services, with many projects contributing to more than one goal. In contrast, of the 49 projects against invasive plants, $98 \%$ (48) provided benefits to protection of biodiversity, while $47 \%$ (23) protected products, and 25\% (12) preserved ecosystem services, again with many projects contributing to several goals. We classified projects into complete control (pest generally no longer important), partial control (control in some areas but not others), and "in progress," for projects in development for which outcomes do not yet exist. For insects, of the 21 projects discussed, 62\% (13) achieved complete control of the target pest, 19\% (4) provided partial control, and 43\% (9) are still in progress. By comparison, of the 49 invasive plant projects considered, 27\% (13) achieved complete control, while 33\% (16) provided partial control, and 49\% (24) are still in progress. For both categories of pests, some projects' success ratings were scored twice when results varied by region. We found approximately twice as many projects directed against invasive plants than insects and that protection of biodiversity was the most frequent benefit of both insect and plant projects. Ecosystem service protection was provided in the fewest cases by either insect or plant biological control agents, but was more likely to be provided by projects directed against invasive plants, likely because of the strong effects plants exert on landscapes. Rates of complete success appeared to be higher for insect than plant targets (62\% vs $27 \%$ ), perhaps because most often herbivores gradually weaken, rather than outright kill, their hosts, which is not the case for natural enemies directed against pest insects. For both insect and plant biological control, nearly half of all projects reviewed were listed as currently in progress, suggesting that the use of biological control for the protection of wildlands is currently very active.
\end{abstract}

(c) 2010 Elsevier Inc. All rights reserved.

\section{Introduction}

Natural ecosystems and their component species are experiencing catastrophic and rapid loss as habitat is destroyed for human use and invaded by species from other biogeographical areas (Simberloff et al., 1997; Cox, 1999; Lockwood et al., 2006). Political solutions may be devised to stop habitat loss, and restraints and economic incentives used to reduce human exploitation of natural habitats. However, damage from invasive species cannot easily be reversed. While better legislation and detection tools will be paramount in preventing new invasions, invaders - once established often persist indefinitely and spread to their ecological limits. Reducing damage in small areas with chemical or physical/ mechanical control is possible for some species if funds and staff are available. But at the landscape level, these tools work only if the infested area is small or sufficiently isolated to prevent quick re-infestation. However, on continents, most invasive plants and insects cannot easily be eradicated. For landscape-level suppression or prevention of emerging damage from an expanding invasion, classical biological control should be considered because if successful it brings about desired ecological change over large areas without repeated cost or treatment of the entire infested area (Van Driesche et al., 2008). Other management practices that can be effective at landscape scales against invasive plants (but rarely, insects) include changes in land use, grazing, or fire management, and manipulation of nutrients or hydrology. For successful control of invasive plants, it may be necessary to integrate one or more of these approaches with biological control.

Biological control efforts against plants and insects have different histories, with insect biological control being used for much of its first century largely against crop pests. Only in the1990s did insect biological control against environmental pests develop as an independent goal (Van Driesche, 1994). In contrast, biological control efforts were rarely focused on invasive plants infesting crops. Rather, invasive plants in forests, grasslands, and aquatic areas were targeted to preserve timber, forage, water, and navigation
(Huffaker, 1957). Over time, protection of native biodiversity and ecosystem function also became major goals of biological control of invasive plants (Van Driesche and Bellows, 1996).

Biological control projects have successfully contributed to the protection of the flora and fauna of many natural ecosystems, and are presently a component in many recovery plans (e.g., Causton, 2001 for Galápagos plants) and restoration efforts worldwide. Benefits of biological control in natural areas also include the preservation of wildlands as sources of renewable resources and recreational use. Finally, biological control programs have proven effective in the protection of some ecosystem services such as flood control, fire regulation, and maintenance of healthy soils.

Damage to natural ecosystems from biological control agents is also a potential outcome. For example, in North America the tachinid Compsilura concinnata, introduced for the control of the gypsy moth (Lymantria dispar) may be responsible for regional declines of several saturniids and other moths in the northeastern USA (Boettner et al., 2000; Schweitzer et al., 2010). The non-target effects of biocontrol agents on native insects on islands, and especially Hawaii, have received considerable attention (Howarth, 1991; Henneman and Memmott, 2001). Risks posed by biological control introductions have been the focus of several reviews, and we refer readers to these: Howarth (1991), Simberloff and Stiling (1996), Lynch and Thomas (2000), Pemberton (2000), Louda et al. (2003), and van Lenteren et al. (2006), among others. We do not review non-target impacts and important cases of such effects exist, particularly for projects directed against agricultural or pasture pests, which are outside the scope of this article. Limited mention is made here of such important impacts if they pertain to the species covered in this article.

Here we focus on the benefits of classical biological control as a tool for ecosystem preservation and restoration, especially given the fact that more biological control projects will needed in the future to correct damage from the increasing number of invasive plants and insects that are establishing in new communities worldwide. Over the course of coming decades, we foresee an expanding 
need for carefully planned and professionally monitored biological control programs in wildlands that will require the joint efforts of biological control practitioners, invasion biologists, ecologists, taxonomists, policy makers, and conservation specialists.

\section{Protecting biodiversity in natural ecosystems}

Loss of native biodiversity is the most enduring consequence of alien species invasions; here we discuss the contribution of classical biological control to reversing such losses, in a variety of natural habitats (wetlands, forests, grasslands, deserts/shrublands, coastal/sand dune, and island communities). Effects of invasive species commonly cascade from the attacked species, upward or downward, affecting other members of the food web such as specialized herbivores, or their parasitoids and predators. The benefits of successful biological control also ramify through ecosystems, and where known these are also discussed.

\subsection{Aquatic and wetland habitats}

Invasive aquatic plants can cause radical changes in even pristine aquatic systems, either by physically altering the habitat or by strong plant-plant competition between the invader and native plants for resources. No examples were found of biological control of invasive insects in aquatic systems. Consequently, here we discuss only invasive plants, of which many species have been subject to biological control. These invasive plants are grouped as (1) floating/emergent species that can cover the surface of water bodies, (2) submerged plants that take resources from native macrophytes, and (3) other species that grow in wetlands but are not themselves aquatic species.

\subsubsection{Floating or emergent species}

Floating plants strongly affect the physical character of the habitats they invade (Toft et al., 2003), and therefore their effects on biodiversity have much in common across several invasive species. Layers of invasive plants cover the water surface, sequester nutrients, and block sunlight from reaching submersed native macrophytes. Light-deprived submerged plants photosynthesize at lower rates and thus produce less oxygen, which when combined with lower rates of physical aeration by wind and waves (due to damping by floating plant mats) leads to less dissolved oxygen (Ultsch, 1973), more $\mathrm{CO}_{2}$ and $\mathrm{H}_{2} \mathrm{~S}$, and lower $\mathrm{pH}$ (Mitchell, 1978; Thomas and Room, 1986a). These changes make the habitat less suitable for native invertebrates (Hansen et al., 1971) and fish. Death of native plants eliminates the foundation for the native food web, with cascading effects on herbivores and predators. Five floating invasive plants of major importance have been targets of successful biological control: Azolla filiculoides (Hill and McConnachie, 2009), Eichhornia crassipes (Coetzee et al., 2009), Salvinia molesta (Julien et al., 2009), Pistia stratiotes (Neuenschwander et al., 2009), and Alternanthera philoxeriodes (Buckingham, 2002).

Azolla filiculoides (red fern) infested much of South Africa by the 1990s (Hill, 1999), forming mats that affected biodiversity (Gratwicke and Marshall, 2001). It caused the near extinction of the rare fish Sandelia bainsii by altering its last remaining habitat (Cambray, Albany Museum, personal communication). The North American weevil Stenopelmus rufinasus was released in 1997. It established and dispersed widely, and very rapidly provided complete control of the weed wherever it occurred (McConnachie et al., 2004), allowing recovery of affected water bodies (Hill and McConnachie, 2009).

Eichhornia crassipes (waterhyacinth) infestations have altered the ecology of water bodies in the southern USA, Mexico, East and West Africa, India, and other warm regions. Weed mats reduce light reaching submerged plants and deplete oxygen, depressing phytoplankton (McVea and Boyd, 1975) and microinvertebrates (Hansen et al., 1971). Benthic invertebrates beneath E. crassipes mats were less diverse than under open water in the New Year's Dam reservoir in South Africa (Midgley et al., 2006). Similarly, E. crassipes mats lowered diversity of littoral macroinvertebrates on Lake Victoria (Masifwa et al., 2001). Varying levels of biological control of waterhyacinth have been achieved with two species of Neochetina weevils on the Nile River in the Sudan (Beshir and Bennett, 1985), the southern USA (Center et al., 2002), South Africa, West Africa, Malawi, Lake Victoria, and Papua New Guinea (Coetzee et al., 2009). In Lake Victoria, biological control reduced waterhyacinth to about $5-10 \%$ of its peak levels (Wilson et al., 2007; Anonymous, 2000; Julien, personal communication). In Benin, following successful biological control of $E$. crassipes, fish populations (Citarhinus spp.) rebounded (Ajuonu et al., 2003; Neuenschwander, personal communication).

Salvinia molesta (giant salvinia), a South American floating fern, formed thick mats on lakes and river oxbows in Australia, Papua New Guinea, parts of the USA, and parts of Africa, especially the Congo basin. Its biological control has been successful in Australia (Room et al., 1981), Papua New Guinea (Thomas and Room, 1986a), the Congo (Mbati and Neuenschwander, 2005; Diop and Hill, 2009), and 14 other countries, through releases of the weevil Cyrtobagous salviniae (Julien et al., 2009).

Invasions of water lettuce ( $P$. stratiotes) led to similar floating plant mats on lakes in Australia, the southern USA, and Congo. Water lettuce has been controlled in Papua New Guinea and Australia (Harley et al., 1990), several regions in Africa (Mbati and Neuenschwander, 2005; Ajuonu and Neuenschwander, 2003; Neuenschwander et al., 2009), and warm parts of North America (Dray and Center, 1992), most often with the weevil Neohydronomus affinis. Infested lakes, once matted over by water lettuce, are now open (e.g., Mbati and Neuenschwander, 2005). Elimination of water lettuce and giant salvinia mats reversed the physical and chemical habitat changes discussed above that are commonly produced by floating invasive plants.

Alternanthera philoxeriodes (alligator weed) is an emergent species that roots on shore or in shallow water and then produces recumbent stems that develop into floating mats. These mats restrict light and oxygen and lead to anaerobic conditions, which in turn affect native flora and fauna. Infestations also increase siltation and reduce flow (Coulson, 1977; Julien, 1995). In the southern USA, Australia, New Zealand, and China, the introduced flea beetle Agasicles hygrophila, either alone or with the crambid moth Arcola malloi, effectively destroyed floating alligator weed mats and prevented their regrowth (Coulson, 1977; Julien, 1981; Julien and Griffiths, 1998; Sainty et al., 1998). The weed is now restricted to banks and shallow margins, so impacts on aquatic biodiversity have largely been eliminated.

\subsubsection{Submersed species}

The principal submersed invasive species against which biological control has been attempted is Hydrilla verticillata (hydrilla). It is a disturbance specialist that rapidly colonizes areas and forms surface canopies that block out the light. It has a broad tolerance range and thrives in many habitats. It matures quickly and propagates and disperses by fragmentation. Hydrilla beds displace native plants and degrade infested habitats (Holm et al., 1997). Four natural enemies of hydrilla have been released in the USA (Balciunas et al., 2002). In Lake Seminole, Florida, damage to hydrilla by an introduced dipteran leafminer, Hydrellia pakistanae, was associated with an increase in the number of native plant species (Grodowitz et al., 2003) and a general decline in hydrilla competitiveness with other plants (Grodowitz, personal communication). However, hydrilla continues to be a serious problem in many areas and the introduction of additional agents will be needed, perhaps together with 
reintroduction of propagules of native plants, to restore invaded communities.

\subsubsection{Other invaders damaging to wetlands}

Wetland communities have also been invaded by such nonaquatic plants as the tree Melaleuca quinquenervia, the climbing fern Lygodium microphyllum, the shrub Mimosa pigra, and the herbaceous perennials Lythrum salicaria and Fallopia japonica. Through a mixture of habitat change and competition, these plants strongly affect native biodiversity. Biological control of all five species is underway, or already achieved.

Melaleuca quinquenervia aggressively invades wetlands in Florida and the Caribbean, forming monospecific stands that displace native vegetation and degrade wildlife habitat (Rayamajhi et al., 2002). Melaleuca reduced biodiversity of freshwater marshes in south Florida by 60-80\% (Austin, 1978). Introduced biological control agents (especially the weevil Oxyops vitiosa and the psyllid Boreioglycaspis melaleucae) have curtailed the tree's reproduction, greatly reducing its spread (Pratt et al., 2005; Tipping et al., 2008; Rayamajhi et al., 2008). Biological control agents have reduced seed production and seedling survival (Center et al., 2007; Rayamajhi et al., 2007; Tipping et al., 2009), killing 85\% of seedlings, saplings, and suppressed understory trees. This has led to a corresponding decrease in melaleuca cover and a fourfold increase in plant biodiversity (Rayamajhi et al., 2009). Combined with cutting and chemical control, biological control is helping to suppress melaleuca in Florida (see Plate 1).

Old World climbing fern, L. microphyllum, also threatens the Everglades and other south Florida habitats, where it dominates Everglade hammocks, cypress swamps, and pine flatwoods (Pemberton and Ferriter, 1998). Two-thirds of southern Florida is susceptible to invasion by this weed (Volin et al., 2004). The pyralid moth Neomusotima conspurcatalis and the gall mite Floracarus perrepae have been introduced and become established (Boughton and Pemberton, 2009; Boughton and Pemberton, unpublished data). The moth has spread rapidly, defoliating the fern around release sites (Boughton and Pemberton, 2009), and some defoliated areas have already been repopulated by native plants (Boughton and Pemberton, 2009).

Mimosa pigra is an aggressive invader of tropical wetlands in Australia, Asia, and Africa. In Australia, it occurs particularly in wetland margins, lakes, and channels with a long period of inundation and disturbance by feral animals. It also spreads into open plains and swamps (Cook et al., 1996). It currently occupies $800 \mathrm{~km}^{2}$ of northern Australian wetlands and threatens $40,000 \mathrm{~km}^{2}$. Invasion converts several vegetation structural types into homogeneous mimosa shrublands with greatly reduced biodiversity (Braithwaite et al., 1989). Infestations threaten many vulnerable plant and animal species (Walden et al., 2004), as further discussed under "Ecosystem Services/Provision of habitat for vertebrate wildlife." Both of two fungal species and nine of 13 insect agents released in Australia have established. Although it has been difficult to separate their impacts, both the sesiid borer Carmenta mimosa and the leafmining gracillariid Neurostrota gunniella have reduced seed rain and seedling regeneration, lowered seed banks, and caused the retreat of mimosa at stand edges (Heard and Paynter, 2009). Seed banks are $90 \%$ below pre-biological control levels. The impacts of the more recently released agents have not been measured, but appear substantial.

Lythrum salicaria (purple loosestrife) is a Eurasian perennial that has extensively invaded wetlands across the northern USA and adjacent areas in Canada. Loosestrife monocultures damage populations of specialist wetland plants, birds, amphibians, and insects (Blossey et al., 2001b; Brown et al., 2006; Maerz et al., 2005a; Schooler et al., 2009). In Oregon, purple loosestrife infestations have lowered plant and insect diversity in tufted hairgrass (Deschampsia cespitosa) communities (Schooler et al., 2006) and affected insect diversity in estuarine habitats important for juvenile salmon migration (Schooler et al., 2009). Four biological control agents - the leaffeeding beetles Galerucella calmariensis and Galerucella pusilla, the root-mining weevil Hylobius transversovittatus, and the flowerfeeding weevil Nanophyes marmoratus - were widely released (Blossey et al., 2001b). Stand defoliation occurred within 4 years at some release sites and later occurred more widely (Blossey et al., 2001b). Although impacts varied among sites (Denoth and Myers, 2005; Grevstad, 2006; Landis et al., 2003), these herbivores suppressed $L$. salicaria in many habitats. Assessments in Michigan found that $G$. calmariensis established, spread, and reduced plant height by 61-95\% (Landis et al., 2003). Purple loosestrife abundance is best suppressed where both leaf beetles and the root weevil are present (Blossey, unpublished data). In many areas where loosestrife has been suppressed, native species have returned (Landis et al., 2003). However in others, invasive hybrid cattails (Typha $\times$ glauca), Phragmites australis (Type $\mathrm{M}$ ), or reed canary grass (Phalaris arundinaceae) (Schooler, 1998) have expanded.

Fallopia japonica (Japanese knotweed) invades riparian areas in Europe and the northern USA, damaging native flora and associated fauna, especially amphibians (Maerz et al., 2005b; Gerber et al., 2008). The Japanese psyllid Aphalara itadori is host-specific (Shaw et al., 2009) and its release for biological control of Japanese knotweed is anticipated in the UK in 2010, which will be the first classical weed biological control introduction in Europe.

\subsection{Boreal and temperate forests}

Natural forest ecosystems have been strongly affected by both invasive insects that kill native trees and invasive plants that compete with native plants.

\subsubsection{Invasive insects}

Biological control projects against invasive forest insects were initiated in North America to protect threatened lumber sources. Classical biological control of forest pests was rare in Europe due to a lack of important invaders and rare in the Southern Hemisphere because forestry, and hence associated biological control, was largely based in plantations of exotic trees. North American projects to protect lumber supplies also protected forest biodiversity, which had been eroded by invasions of tree-killing insects and pathogens (Campbell and Schlarbaum, 1994, 2002). However, few efforts were made during this period to document impacts of invasive species on forest biodiversity or improvements following biological control of the invasive pests, except for effects on the attacked tree species.

2.2.1.1. Tree-killing borers. Beginning in the 1980s, increased shipment of containerized goods from Asia to the USA facilitated the establishment of several wood boring beetles that were transported as larvae or pupae in wooden crates and pallets. The most damaging species was the ash-feeding buprestid Agrilus planipennis (emerald ash borer), discovered in Michigan in 2002. Ecological damage from this invasion includes $>80 \%$ mortality of several species of ash at many locations, including rare species such as pumpkin ash (Fraxinus profunda) (Bauher, personal communication). Ash is a dominant or co-dominant in many forest communities, particularly in mesic woodlands and riparian areas (MacFarlane and Meyer, 2005), and many of these habitats have been severely affected. Six ash species were attacked in the central USA by 2009, while several others in western North America are threatened. Twenty-one species of moths are monophagous on Fraxinus (Wagner, 2007), of which five sphingids - Ceratomia undulosa, Manduca jasminearum, Sphinx canadensis,Sphinx chersis, Sphinx franckii - are particularly vulnerable to extinction due to tree death from emerald ash borer. Three parasitoids (Oobius agrili, Tetrastichus plani- 

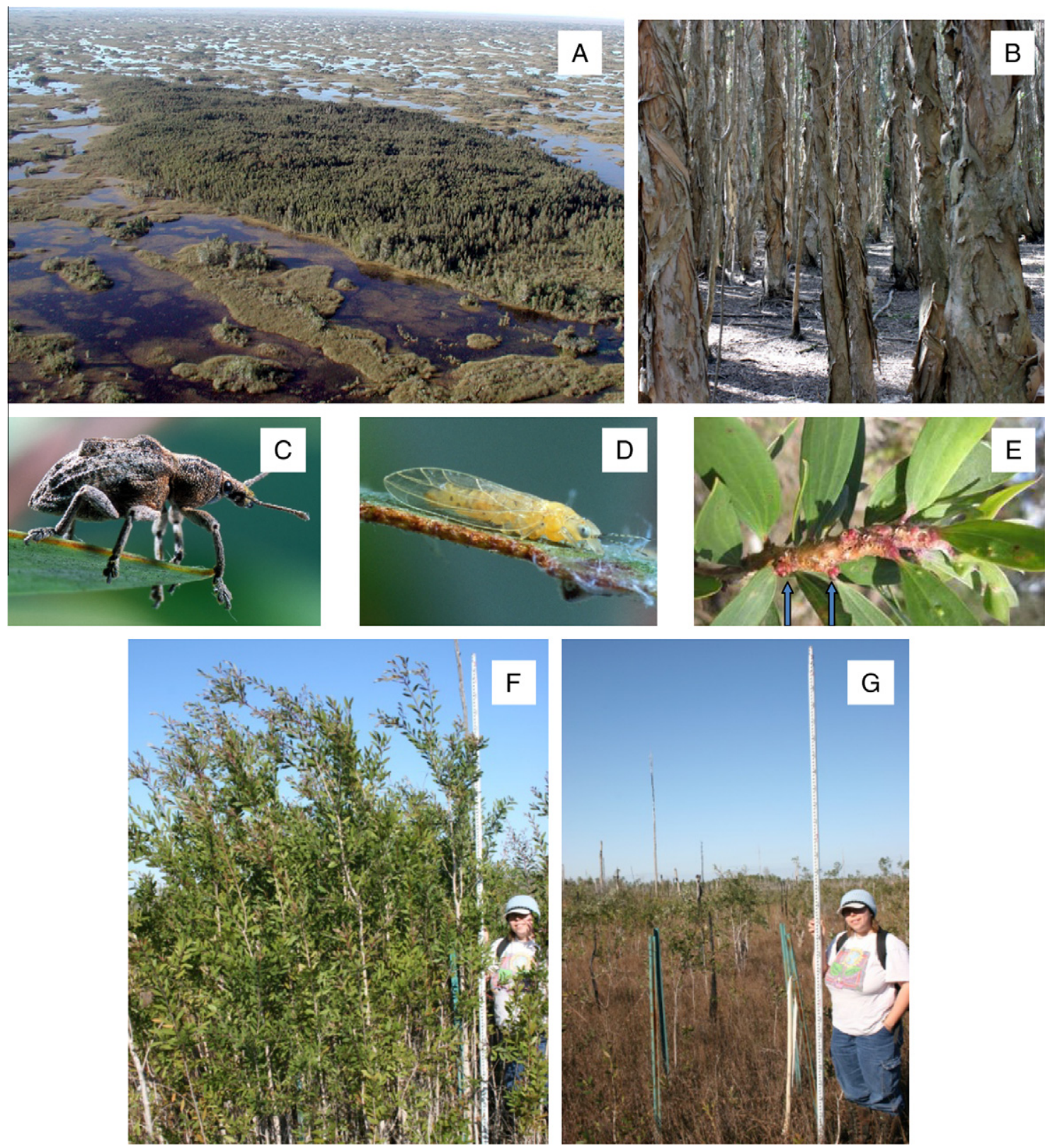

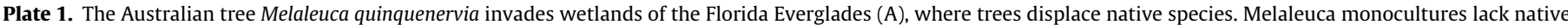

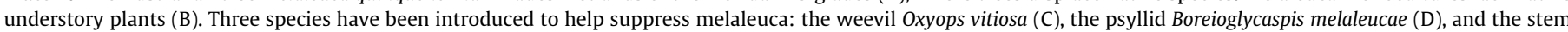

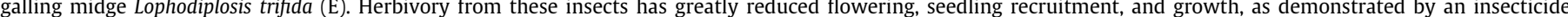

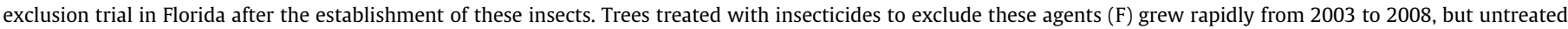

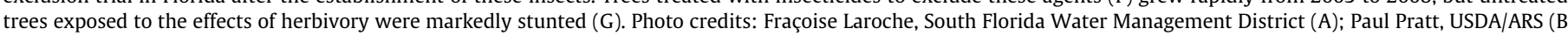
and E); and Steve Asmus, USDA/ARS ( $C$ and D); Phil Tipping, USDA/ARS (F and G).

pennisi, and Spathius agrili) from China that attack this borer were collected, screened for host-specificity, released, and recovered (Bauer et al., 2007; Duan et al., unpublished data) and their impact is presently being evaluated.

A second invasive tree-killing invasive beetle, the great spruce bark beetle (Dendroctonus micans), is a Siberian species that has spread west to the UK and south to Turkey since the 19th century. As the beetle expanded its range, it apparently outpaced the spread of its specialized natural enemies, leading to serious outbreaks in Western Europe and the Caucasus region, causing widespread mortality of spruce (Picea spp.) (Grégoire, 1988). In Western Europe damage occurred most often in plantations, but in Georgia and northeastern Turkey the beetle seriously affected natural stands of oriental spruce (Picea orientalis), a tree of high regional ecological significance that stabilizes steep slopes (Kobachidze, 1967; Grégoire, 1988). A host-specific predatory beetle, Rhizophagus grandis, associated with low, stable populations of $D$. micans in Siberia was released in Georgia, Turkey, and Western Europe, and significantly lowered spruce beetle populations and tree mortality in most locations (Fielding and Evans, 1997).

2.2.1.2. Sucking insects. High densities of invasive Hemiptera can devitalize and even kill their hosts. In temperate forests, an invasive adelgid and a cypress aphid have had such effects. Hemlock woolly adelgid (Adelges tsugae) spread in the USA from its point of invasion in 1951 in Virginia south to Georgia and north to Maine. South of Massachusetts, it caused high levels of mortality of eastern hemlock (Tsuga canadensis) and Carolina hemlock (Tsuga caro- 
liniana) and affected hemlock-dependent organisms in the Appalachian Mts. (Evans, 2002), where eastern hemlock is the only species whose canopy produces dense shade. In the Delaware River Basin, hemlock deaths affected stream insects (Snyder et al., 2002), brook trout (Ross et al., 2003), and various understory plants (Eschtruth et al., 2006), with species requiring cooler temperatures being replaced by ones adapted to warmer habitats. Because native predators were unable to prevent adelgid outbreaks (Montgomery and Lyon, 1996), predators were sought in the adelgid's native range, including coccinellids from China and Japan, and Laricobius (Derodontidae) beetles from western North America, China, and Japan. The coccinellids Sasajiscymnus tsugae, Scymnus ningshanensis, and Scymnus sinuanodulus and the derodontid Laricobius nigrinus have been introduced to the eastern USA (Cheah and McClure, 1998; McClure et al., 2000; Lu and Montgomery, 2001; Montgomery et al., 2002; Zilahi-Balogh et al., 2002, 2003). Laricobius nigrinus established well at 13 of 22 release sites (Mausel, unpublished data) and spread in the Appalachian Mts. Biological control investigations continue on this invasive insect.

In Africa, the invasive cypress aphid (Cinara cupressivora) spread rapidly from Malawi in 1986 into neighboring countries and attacked native Cupressaceae trees, causing dieback (Watson et al., 1999; Day, R., et al., 2003). Heavy infestations killed mature trees and, in Malawi, threatened the endemic, endangered Mulanje cedar, Widdringtonia whytei, on the Mt. Mulanje massif (Baylis et al., 2007). In Kenya, it attacked Juniperus procera, an important native tree in many watersheds. By 2003, the aphid invaded Colombia, Brazil, Bolivia, and Chile, attacking various Cupressaceae, including the Cordilleran cypress Austrocedrus chilensis (Baldini et al., 2007). Release of the braconid Pauesia juniperorum in Africa began in 1994 and its establishment was confirmed in Malawi and Kenya by 1996 (Day, R., et al., 2003). Aphid densities declined in the mid 1990s in Africa, and this decline was associated at least in part with this parasitoid (Kairo, personal communication).

2.2.1.3. Defoliating sawflies and moths. From the last decades of the 19th century to the early 20th century, a series of European sawflies and moths invaded North American forests. The invasive sawflies especially affected pine and spruce. White pine (Pinus strobus), abundant in many northeastern forests, was commonly defoliated after 1910 by Diprion similis. Spruce (Picea spp.) forests in eastern Canada and Maine were extensively defoliated in the 1930s by Gilpinia hercyniae (Van Driesche et al., 1996). Biological control programs suppressed both species, $D$. similis being controlled by introduced parasitoids (especially Monodontomerus dentipes) (McGugan and Coppel, 1962) and G. hercyniae by a highly specific nucleopolyhedrovirus probably introduced accidentally along with European parasitoids (Magasi and Syme, 1984).

During this same period, several invasive European moths invaded North American forests, affecting especially larch and oak. Larch forests were defoliated by the coleophorid Coleophora laricella, which first infested eastern larch (Larix laricina) (1886-1950s) and later western larch (Larix occidentalis) (1957-1980s). Better records of impact exist for the western infestation. There, defoliation was principally of new growth (Ryan, 1990). Repeated, intense infestations reduced terminal and radial growth, and caused some tree mortality. Biodiversity impacts on species other than larch were not studied. Two introduced parasitoids, the braconid Agathis pumila and the eulophid Chrysocharis laricinellae, controlled the pest in both eastern (Webb and Quednau, 1971) and western North America (Ryan, 1990), and subsequent outbreaks have been small, brief, and infrequent. In Oregon, larval densities declined $>98 \%$ following biological control introductions (Ryan, 1990).

Also in this era, oaks (Quercus spp.) were affected by the geometrid Operophtera brumata (winter moth) and the lymantriid $L$. dispar (gypsy moth). Winter moth was first reported in 1949 in
Nova Scotia, but later invaded British Columbia and then Massachusetts. Winter moth outbreaks defoliated oaks repeatedly, causing up to $50 \%$ mortality. Winter moth's populations were suppressed in both Nova Scotia (Embree, 1971) and British Columbia (Embree and Otvos, 1984) by introduced parasitoids, mainly the tachinid fly Cyzenis albicans. In Nova Scotia, outbreaks collapsed within 3 years once C. albicans parasitism reached $10 \%$ (Embree, 1971). Moth densities dropped from >1000/tree in 1954 to $<1 /$ tree in 1963.

In Massachusetts by the late 1800s, the gypsy moth began defoliating oaks and other hardwoods over an ever increasing area (McManus and McIntyre, 1981) - stripping 10.7 million ha of forest in the USA in the outbreak of 1980-1982 and 5.8 million ha in the outbreak of 1989-1991 (USDA Forest Service website). In many areas, oak mortality caused stand composition to shift toward sweet birch, black gum, red maple, and tulip poplar (Muzika and Gottschalk, 1995). Control programs directed against gypsy moth with aerial forest pesticide applications (1950-1980) endangered more than a dozen species of rare eastern butterflies and moths (Schweitzer et al., 2010). Many natural enemies were introduced against gypsy moth starting in 1905 (Doane and McManus, 1981) and continuing to 2000 (Ertle, personal communication). These efforts achieved widespread establishment of one predator and six parasitoids (Van Driesche et al., 1996), and the accidental establishment of one fungus, Entomophaga maimaiga. Apart from the periphery of the infested area, no large-scale pesticide applications have been necessary to control gypsy moth since 1989, likely due to fungal epizootics (Webb et al., 1999) and the introduced parasitoids. One introduced generalist parasitoid, the tachinid $C$. concinnata, attacks many native moths and is held to be a threat to native silkmoths (Boettner et al., 2000) and a variety of other native lepidopterans (Schweitzer et al., 2010).

2.2.1.4. Gall makers. Gall insects are generally not considered important as determinants of plant density but an appreciation of the strength of their impacts is developing based on their successful use as biological control agents (Muniappan and McFadyen, 2005) and the damage that some invasive gall makers have caused to native plants (e.g., Gramling, 2005). In temperate forests, the invasive chestnut gall wasp (Dryocosmus kuriphilus) damaged native trees in Asia, North America, and Europe. This Chinese species invaded Japan (1940s), Korea (1950s), the USA (1970s), and Italy (Quacchia et al., 2008). In all invaded regions, it caused significant damage to native Castanea species, galling shoots, reducing tree vigor, preventing flowering, and killing trees (Kato and Hijii, 1997; Cooper and Rieske, 2007). In Japan and southern Europe, Castanea species are an important component of native forests, providing food for wildlife, bee forage, soil improvement, and slope stabilization in mountains (Howes, 1979; Thomas et al., 1992; Quacchia et al., 2008). In the USA, D. kuriphilus threatened to retard the recovery program for American chestnut (Castanea dentata) in Appalachian and New England forests (where chestnut was previously devastated by the introduced fungus Cryphonectria parasitica [Cooper and Rieske, 2007]). The Chinese parasitoid Torymus sinensis reduced galling to non-pest levels in Japan (Moriya et al., 2003) and the USA (Cooper and Rieske, 2007). Its release in Italy (Quacchia et al., 2008) is too recent to evaluate.

\subsubsection{Invasive plants}

Many weeds have invaded temperate forests and their number, area of infestation, and importance are increasing. However, only a few have been targets for biological control. Here we discuss four projects (a vine, an herb, and two trees) that are under way in North America but have not yet controlled their targets. Assessing the value to native biodiversity of such projects is limited by the general lack of pre-release studies on damage to native flora and 
fauna from invasive plants (Morin et al., 2009), in part, because such effects develop slowly over long periods of time.

2.2.2.1. Mile-a-minute weed. Persicaria perfoliata, a spiny annual vine of Asian origin, developed extensive monocultures in disturbed open areas in the mid-Atlantic region of the USA after its invasion into Pennsylvania in the1930s (Hough-Goldstein et al., 2008). It inhibited both commercial reforestation and natural forest regeneration and interfered with the recreational use of natural areas. It reduced the quality of wildlife habitat and out-competed native plants, presumably due to its early germination, rapid growth, and ability to climb over other plants (Wu et al., 2002). A host-specific Asian weevil, Rhinoncomimus latipes, was released and established at sites throughout the range of mile-a-minute weed (Hough-Goldstein et al., 2009). At release sites, spring densities of the plant declined by $75 \%$ within $2-3$ years, compared to no change at control sites. Benefits to native biodiversity, as mile-aminute weed densities continue to decline, are being monitored.

2.2.2.2. Tree of heaven. The Chinese tree Ailanthus alitissima has invaded 41 of the contiguous 48 US states, where it often out-competes native pioneer plants due to its ability to survive harsh conditions, sprout from cut stumps, and produce large number of seeds. It also affects vegetation through the release of allelochemicals (Voigt and Mergen, 1962). Significant funding was allocated annually to control the weed in national and state parks, but these efforts had limited effect. A classical biological control program against tree of heaven was initiated in 2004 with the weevil Eucryptorrhynchus brandti, which causes mortality of $A$. altissima in China (Ding et al., 2006). Of 28 plant species examined in nochoice feeding tests in quarantine, adult feeding occurred only on corkwood (Leitneria floridiana) and choice tests demonstrated a strong preference for A. altissima (Kok et al., 2008). Tests assessing development of immature stages and egg maturation by adults are underway.

2.2.2.3. Garlic mustard. Alliaria petiolata is a cool-season, shade-tolerant, obligate biennial herb that invades forests. First detected in New York in 1868 (Nuzzo, 1993), it has since spread across the northern USA (Blossey et al., 2001a). Dense garlic mustard stands can displace native herbaceous plants and may harm insects, ground-nesting birds, reptiles, amphibians, and rodents (Blossey et al., 2001a). It is an oviposition sink for one native butterfly, Pieris virginiensis (Porter, 1994), whose larvae are unable to complete development on garlic mustard (Courant et al., 1994) and is a partial egg sink for a second species, Pieris oleracea, which shows variation in its ability to develop successfully on the plant (Keeler and Chew, 2008). Garlic mustard also damages the mycorrhizal associations essential to many native plants (Callaway et al., 2008). Surveys of its associated insects in Europe identified four weevils as potential biological control agents (Blossey et al., 2001a). Demographic modeling (Davis et al., 2006) suggested that the root-feeding weevil Ceutorhynchus scrobicollis is the most promising species, but that stem-mining or seed-feeding weevils may also be needed. Advanced host-specificity testing is underway for C. scrobicollis and preliminary work is in progress for the three other species.

2.2.2.4. Chinese tallow tree. Triadica sebifera is a tree native to China that is invading warm temperate forests and meadows of the southeastern USA (Richard et al., 2004; Pattison and Mack, 2007). Its seeds are readily dispersed by birds and it has the potential to spread throughout most of eastern North America. A biological control program against Chinese tallow tree has been initiated to evaluate the impacts of seed-feeding herbivore insects, with the goal of restricting dispersal. A leaf-rolling weevil, Heterapoderopsis bicallosicollis, was found to be host-specific to the plant
(Wang et al., 2009) and has been imported from China into quarantine for evaluation.

\subsection{Subtropical and tropical forests}

\subsubsection{Invasive insects}

Tropical or subtropical forests have greater biodiversity than temperate area forests and thus more species potentially at risk from invasive insects. However, effects of invasions may go unrecognized because inventories of tropical biotas are more preliminary than those of temperature communities. We discuss nine examples.

2.3.1.1. Bromeliad weevil. Metamasius callizona is native to Mexico and Guatemala. Its larvae mine meristematic tissue of bromeliads and kill plants. Importation of infested bromeliads from Veracruz, Mexico brought this weevil to Florida around 1989 (Frank and Thomas, 1994), where it now severely damages eight of Florida's native epiphytic bromeliads in their natural habitats and is a risk factor for four other rare bromeliads. Most of these are state-listed endangered or threatened taxa, two of which (Tillandsia fasciculata and T. utriculata) are listed expressly because of the threats posed by this weevil. One bromeliad (Tillandsia simulata) is endemic to Florida. Also at risk are at least 14 invertebrates that live in pools of water impounded in leaf axils of these bromeliads and might disappear if their hosts were lost (Frank and Fish, 2008). Biological control of this weevil has been started with the discovery and release of a specialized tachinid (Lixadmontia franki) (Frank and Cave, 2005; Cave, 2008). Evaluations of establishment of the fly are in progress.

2.3.1.2. Lobate lac scale in the Florida everglades. Paratachardina pseudolobata, an invasive Asian scale found in Florida and the Bahamas, attacks 95 of 155 native south Florida woody plants and 67 of 107 woody plants from the Bahamas. It caused death in 12 species (Pemberton, unpublished data). Scale infestations on four rare plant species, monitored for 2 years in Florida, remained high and caused progressive branch die back on Eugenia confusa and Pavonia paludicola, but declined on Amorpha herbaceae var. crenulata and Dalea carthagenensis (Liu and Pemberton, unpublished data). Comparison of naturally infested wild Psychotria nervosa with plants from which scales were excluded, showed that scales reduced fruit set (Liu and Pemberton, unpublished data). Surveys for natural enemies in India and Sri Lanka, the scale's presumed native range (Pemberton, 2003), found two Indian parasitoids that oviposited in Floridian lac scales, but eggs were unable to complete development because of encapsulation by the host (Schroer and Pemberton, 2007). Subsequently, molecular analysis of the lac scales in Florida showed the Floridian populations of lac scales are a distinct, undescribed species (Schroer et al., 2008), most likely native to Malaysia (Pemberton, unpublished data). Parasitoid collections from this region are planned.

2.3.1.3. Invasive scales affecting Australian forests. In Australia, several exotic scales attacking crops also damaged forest plants, but this impact was largely overlooked. These invasive coccids weakened native plants and their honeydew benefitted invasive ants, compromising native butterfly/ant mutualisms. Biological control of these coccids for crop protection benefitted native forest species. Examples below are drawn from Waterhouse and Sands (2001) and personal observations (Sands, unpublished data)

White wax scale (Ceroplastes destructor) from South Africa invaded Australia before 1893 (Zeck, 1932) and became a pest of fruit crops and ornamentals (Snowball, 1969). It also damaged native plants along roads, in woodlands, rainforests, and other natural ecosystems in temperate and subtropical eastern Australia. Principal hosts along roadsides were Bursaria spinosa and Dodonaea 
triquetra; in woodlands, Pittosporum undulatum; and in rainforests, Auranticarpa rhombifolia, Syzigium spp. (Waterhouse and Sands, 2001), Hymenosporum flavum, Syzigium australe, and Acmena smithii. Heavy infestations produced copious honeydew, which nourished invasive tramp ants and sooty molds. Two relatively hostspecific encyrtid parasitoids of white wax scale, Anicetus communis and A. nyasicus, were collected from South Africa (Snowball, 1969) and provided complete biological control (Sands et al., 1986). Since the 1970s, C. destructor has been uncommon in natural plant communities. Infested native plants in the national parks of southeastern Queensland regained vigor and the abundance of honeydew and sooty mold declined. Exotic ants (e.g., Pheiodole megacephala) declined in abundance on native plants formerly infested with wax scales. As a consequence, several native ants have reappeared on plants from which they were formerly excluded. This has benefitted some native, ant-tended lycaenids, such as Hypochrysops miskini and Pseudodipsas cephenes, which require the ant Anonychomyma gilberti, a species now more abundant following biological control of white wax scale. Similarly, in some eucalypt woodlands, the indigenous ant Papyrius nitidus, which attends larvae and pupae of the lycaenid Hypochrysops ignitus, was displaced by exotic ants foraging on the butterfly's scale-infested host plants. However, very few $P$. nitidus have returned to these plants following biological control of white wax scale, and both the butterfly and its attendant ant continue to be scarce.

Pink wax scale, Ceroplastes rubens, of African origin (Quin and Gullan, 1998), became a pest of citrus and ornamentals in Australia, but also fed on rainforest plants such as Ficus spp., Syzygium spp., Shefflera actinophylla, Pittosporum spp. (Smith et al., 1997), Waterhousea floribunda, and Drypetes deplanchei. It is most abundant in exposed locations. The introduced encyrtid Anicetus beneficus controlled the scale on citrus and on some of its native hosts (e.g., S. actinophylla), but not on others (e.g., Syzygium spp.). Heavy infestations in natural settings are now rare, except in forest regeneration plantings. Densities on forest plants no longer attract numerous exotic ants, and thus no longer affect indigenous rainforest species in eastern Australia or Norfolk Island (another formerly infested area).

\subsubsection{Invasive plants}

Invasive plants have been highly damaging in subtropical and tropical forest areas, although as with temperate forest pests, long-term monitoring and careful study of actual damage to native flora have been sporadic. Some examples of invasive plants with developing or completed biological control projects and their benefits follow. Examples occurring on islands (e.g., Miconia calvescens in Tahiti) are treated in another section ("Ocean Island Communities").

2.3.2.1. Mist flower in New Zealand. Ageratina riparia, native to Central America and Mexico, became a significant weed in northern New Zealand by the 1990s. Damage was greatest in river corridors and disturbed areas in native forests, but the weed also infested wetlands and forest margins (Anonymous, 1999). Mist flower was controlled biologically in Hawaii in the 1980s (Trujillo, 2005), and studies suggested the program could be transferred to New Zealand (Morin et al., 1997). The white smut fungus Entyloma ageratinae and the gall fly Procecidochares alani were released in New Zealand in 1998 and 2001, respectively, and the fungus in particular established and spread rapidly. Results were monitored from 1998 to 2008 (Barton et al., 2007; Landcare Research, unpublished data). The percentage of live leaves infected with fungus reached $60 \%$ within 2 years, maximum plant height declined significantly, and in heavy infestations the mean percentage cover of mist flower declined from $81 \%$ to $1.5 \%$. By 2008 , the gall fly reached a mean density of 0.6 galls/stem and the fungus remained abundant (averaging 55\% leaf infection) despite mist flower cover remaining below $1 \%$. As mist flower declined, the species richness and the mean percentage cover of native plants at forest sites increased, with no increase in other invasive plants, except a weak response by African club moss (Selaginella kraussiana). Many plants colonizing plots were native mid- or late-successional shrubs or trees. Concurrent with mist flower reduction, the number of reports of threats to rare endemic plants from mist flower decreased, indicating substantial benefit to native forests (Barton et al., 2007).

2.3.2.2. Cat's claw creeper in Australia. Macfadyena unguis-cati, native to South America, is an environmental weed of the Australian subtropical eastern seaboard, the southeastern USA, South Africa, India, Mauritius, and New Zealand (Downey and Turnbull, 2007). In forested riparian areas, this vine kills mature trees, causes bank destabilization, and is an intense root competitor with native plants (Downey and Turnbull, 2007). Ground-level vines smother low vegetation and prevent recruitment of native plants (Floyd, 1989). Biological control is under way in both South Africa and Australia. In Australia, the tingid Carvalhotingis visenda and the pyralid Hypocosmia pyrochroma have been released (Dhileepan et al., 2007a,b) and impacts are being monitored.

2.3.2.3. Brazilian peppertree in Florida. Schinus terebinthifolius is an invasive South American woody plant that rapidly colonizes both disturbed areas and intact natural habitats in over 20 countries in subtropical regions (Cuda et al., 2006). In Florida, this plant displaced populations of the rare or threatened plants Jacquemontia reclinata (Convolvulaceae) and Remirea maritima (Cyperaceae) (Austin, personal observations, in Langeland et al., 2008) and invaded the nesting habitat of the Florida state-listed gopher tortoise (Gopherus polyphemus). Insects attacking this plant in South America and Florida have been studied as potential biological control agents (Cuda et al., 2006; McKay et al., 2009). Field impact studies in Brazil and host-specificity testing in Brazil and Florida confirmed that a stem-feeding thrips, Pseudophilothrips ichini sensu lato, is a specialist on Brazilian peppertree and the Peruvian peppertree (Schinus molle) (Manrique et al., 2008; Cuda et al., 2009). In 2007, $P$. ichini sensu lato was recommended for field release, but thrips from different source populations were found to be genetically distinct, and more work is required to confirm population-level specificity before release.

2.3.2.4. Air potato in the southeastern USA. Dioscorea bulbifera is an herbaceous vine native to Old World tropics, which is now established along the Gulf of Mexico from Florida to Texas (Wheeler et al., 2007), where it climbs on and out-competes native vegetation for limited resources (Gordon et al., 1999; Wheeler et al., 2007). It occurred in 12 of 48 habitats surveyed in southern Florida (Gann et al., 2001), where it aggressively exploits disturbed sites, such as forest canopies damaged by hurricanes, and impedes the reestablishment of native species (Gordon et al., 1999). A potential biological control agent, the Nepalese leaf beetle Lilioceris nr. impressa, was found to be both damaging to the target weed and safe to native plants. A petition for its release has recently been approved (Pemberton, 2009).

2.3.2.5. Madeira vine in Australia. The South American plant Anredera cordifolia is a serious environmental weed in coastal areas of eastern Australia, Hawaii, New Zealand, and South Africa (VivianSmith et al., 2007). In Australia, Madeira vine threatens several endangered communities (Vivian-Smith et al., 2007) and is detrimental to riparian vegetation, tall open forest, and damp sclerophyll forests (Floyd, 1989). Its prolific growth and ability to climb $40 \mathrm{~m}$ into tree canopies has caused mature trees to collapse under the weight of its vines. Australia and South Africa are coordinating 
biological control efforts. The leaf beetles Plectonycha correntina (Cagnotti et al., 2007) and Phenrica sp. (van der Westhuizen, 2006) have narrow host ranges, but neither insect has yet been released in either country. Further exploration in South America to find additional agents is planned.

\subsection{Grasslands}

As a biome, grasslands of the world have been extensively altered by people for farming and grazing, and a lower percentage of this biome has been conserved than of forests or wetlands. In many areas, grazing by livestock has changed plant competition in favor of invasive, grazing-tolerant exotic species, which themselves have often affected the fire regime, further promoting invasion (Brooks et al., 2004). Only in recent decades have the rich biotas of grasslands been identified as important subjects for conservation and restoration. Invasive plants, including both accidental introductions and grasses sown to increase forage on wildlands, have affected native grassland biodiversity worldwide. While introduced forage species have not been selected by governments for biological control, many invasive forbs have been, particularly in the USA, Canada, Chile, and Australia.

\subsubsection{American grasslands}

Biological control of invasive species affecting US grasslands was begun in order to restore productivity of rangelands infested with European forbs. At least 14 species were targeted for biological control (Nechols et al., 1995; Julien and Griffiths, 1998; Van Driesche et al., 2002), including knapweeds (Centaurea spp.), yellow starthistle (Centaurea solstitialis), tansy ragwort (Senecio jacobaea), St. Johnswort (Hypericum perforatum), spurges (Euphorbia spp.), and thistles (especially Cirsium arvense). The first successful weed biological control project in the USA was in the 1950s against St. Johnswort, an invader in natural grasslands in California. Its successful biological control (Huffaker and Kennett, 1959; McCaffrey et al., 1995) reduced St. Johnswort density by $99 \%$ in open areas, with the plant only persisting is shaded areas. The subsequent recovery of other vegetation was monitored in detail and showed that native grasses such as California oatgrass (Danthonia californica) and blue wild rye (Elymus glaucus) increased in abundance (Huffaker and Kennett, 1959). California oatgrass is used in restoration of degraded California coastal prairies (Buisson et al., 2006).

Another early project resulted in successful biological control of tansy ragwort, reducing the infestation by 93\% in many areas (McEvoy et al., 1991; Turner and McEvoy, 1995; Coombs et al., 1996). In coastal prairies in Oregon, biological control of tansy ragwort led to a $40 \%$ increase of the rare hairy stemmed-checkered mallow (Sidalcea hirtipes) (Gruber and Whytemare, 1997). In California, biological control of tansy ragwort allowed the return of natural plants in coastal prairies, such as California poppy (Eschscholzia californica), beach strawberry (Fragaria chiloensis), Alameda County thistle (Cirsium quercetorum), coyote mint (Monardella villosa), and coyotebrush (Baccharis pilularis) (Pemberton and Turner, 1990). The recent release of one of the two tansy ragwort control agents, the arctiid Tyria jacobaeae in Montana, USA (Markin and Littlefield, 2008) raised concerns of potential non-target effects to Senecio triangularis (McEvoy et al., 2008).

Successful biological control is developing for yellow starthistle (Gutierrez et al., 2005; Pitcairn et al., 2005; Smith, 2007; Woods et al., 2009), leafy spurge (Euphorbia esula) (Cornett et al., 2006; Cline et al., 2008; Samuel et al., 2008), and diffuse (Centaurea diffusa) and spotted (Centaurea stoebe) knapweeds (Smith, 2004; Story et al., 2000, 2006, 2008; Seastedt et al., 2007; Myers et al., 2009). The value of these programs to the native biota of invaded grasslands requires further documentation. Harris (1988) noted that use of herbicides to suppress leafy spurge threatened popula- tions of the western prairie fringed orchid (Plantathera praeclara) in North Dakota. Introduction of Aphthona flea beetles as biological control agents, plus targeted sheep or goat grazing, reduced leafy spurge to acceptable levels in parts of Montana and North Dakota and allowed native forage species to increase (Lym, 2005; Cline et al., 2008; Samuel et al., 2008). Integration of biological control agents with herbicide applications allowed recovery of the threatened orchid (Lym, 2005). A related native Euphorbia species (E. robusta), predicted to be within the host range of one of the leafy spurge control agents (Aphthona nigriscutis), was attacked in the field. However, this plant's population increased in the presence of this agent because of lowered competition pressure from leafy spurge, which declined due to biological control (Baker and Webber, 2008).

Solanum viarum (tropical soda apple), native to South America, has invaded 400,000 ha of grasslands and other natural habitats in Florida since 1988 (Medal et al., 2008). Surveys for biocontrol agents in South America started in 1994 and a leaf beetle, Gratiana boliviana, was released in Florida, Georgia, Alabama, and Texas in 2003-2008 (Diaz et al., 2008; Medal, unpublished data). The beetle established at most release sites in Florida, and caused $30-100 \%$ defoliation and reduced fruiting to virtually zero. Beetles dispersed 1.6-16.0 km/year and non-target effects were not observed during 6 years of monitoring (Medal et al., 2008). Petitions for release in the USA of three additional agents (the weevil Anthonomus tenebrosus and the leaf beetles Metriona elatior and Gratiana graminea) are under review.

Gorse (Ulex europaeus) is an invasive shrub that invades grasslands and other communities in the USA (Markin et al., 1995), New Zealand (Hill and Gourlay, 2002), Australia (Ireson et al., 2003), and Chile (Norambuena et al., 2007), where it forms dense stands that compete with native plants. In the USA, gorse replaced desirable vegetation in salt spray meadows (Coombs et al., 2004). In coastal areas in Oregon, gorse reduced habitat for the plant Lycopodium inundatum and the butterfly Speyeria zerene var. hippolyta (Pratt et al., 2003), and threatened the rare plant Phaceila argentea (Coombs, personal communication). In Chile, mechanical removal of gorse caused damage to Berberis negeriana plants (Norambuena, personal communication) in the Yani Hills $\left(37^{\circ} \mathrm{S}\right)$, which is one of few areas still supporting this endemic barberry (Gomez et al., 2008). Gorse biological control is currently being attempted with ten agents in six countries or islands (Julien and Griffiths, 1998; Hill et al., 2008). The spider mite Tetranychus lintearius reduced gorse dry matter $36 \%$ in Tasmania (Davies et al., 2007), and shoot size and flowering $37 \%$ and $82 \%$, respectively, in Hawaii (Hill et al., 2008; Markin, unpublished data). In Chile, late summer mite outbreaks reduced regrowth and flowering (Norambuena et al., 2007), and the seed weevil Exapion ulicis reduced seed production and seedling establishment (Norambuena, 1995; Norambuena and Piper, 2000).

Also in Chile, invasive blackberries (Rubus spp.) infested 5 million ha of arable or grazing land (Oehrens, 1977). The rust Phragmidium violaceum, was introduced for its control, became widely established within 3 years, and reduced the size and competitiveness of Rubus. Partial control of blackberry allowed an increase in the native pioneer shrub Aristotelia chilensis, a species important in limiting erosion (Oehrens, 1977; Oehrens and Gonzalez, 1977).

In the eastern USA, grasslands have been invaded by several weeds, some of which are the same as discussed above. Invaders unique to this area include two species of European swallow-worts, Vincetoxicum nigrum and Vincetoxicum rossicum, which are lethal oviposition sinks for monarch butterflies (Danaus plexippus) (Casagrande and Dacey, 2007). At high densities, they also lower site quality for nesting grasslands birds (DiTomaso et al., 2005). In Vermont, black swallow-wort ( $V$. nigrum) threatens the endangered Jessop's milkvetch, Astragalus robbinsii (DiTomaso et al., 2005). 
Surveys in Europe identified several potential biological control agents, which were collected for further study in US quarantine.

\subsubsection{Australian grasslands}

Grasslands constitute a high proportion of the Australian landscape. Consequently, plants invasive in this biome are of special importance, and many exotic plants are of concern across several regions of the country, including dry and wet tropical savannahs in Queensland and the Northern Territory. Lantana, Lantana camara (Verbenaceae), is perhaps the oldest target for biocontrol in Australia (Day, M.D., et al., 2003). It is found along the east coast and the Great Dividing Range from Cape York to southern New South Wales. Where abundant, lantana blocks plant succession, displaces native species, changes structure and floristics of natural communities, and decreases species richness (Day, M.D., et al., 2003; Day and Zalucki, 2009). It has also proven an extremely difficult biological control target because of its high genetic diversity caused by multiple (horticultural) introductions and subsequent hybridization (Swarbrick et al., 1995; Day, M.D., et al., 2003). Thirty biocontrol agents have been released in Australia over nearly a century. Several agents are effective in some areas (Day and Zalucki, 2009), but the plant remains at pest levels in most locations.

In the dry tropics of Queensland, rubber vine (Cryptostegia grandiflora) from Madagascar invaded forested areas along rivers and later spread into adjacent grasslands and savanna (Tomley, 1995). In riparian areas, dense stands killed eucalyptus trees and reduced native biodiversity. Successful biological control in drought-prone areas has been achieved by the rust Maravalia cryptostegiae (Evans and Tomley, 1994; Vogler and Lindsay, 2002) and, to a lesser extent, the pyralid moth Euclasta whalleyi (Mo et al., 2000), allowing increased growth of local grass species.

In central Queensland, Parthenium hysterophorus has invaded large areas and displaced native perennial grasses. Its domination of seedbanks suggests it has substantial impact on native plant communities (Navie et al., 2004). While nine biological control agents failed to establish or were ineffective, two species, the leaf-feeding beetle Zygogramma bicolorata and the stem-galling moth Epiblema strenuana, have controlled the plant in some areas (Dhileepan, 2003).

\subsection{Deserts and arid shrublands}

Several invaders of deserts and arid shrublands have been targets of weed biological control, including cacti (especially Opuntia spp.), saltcedars (Tamarix spp.), tumbleweeds (Salsola spp.), mesquite (Prosopis spp.), and hakea (Hakea sericea).

Opuntia cacti (native to the Neotropics), became widely invasive in dry regions of the Old World, especially Australia and South Africa, where native cacti do not occur. Invasive Opuntia cacti were successfully suppressed with biological control in both of these areas (Dodd, 1940; Zimmermann et al., 2009), but projects either were organized to restore rangeland productivity or remove cacti from parks, and effects on biodiversity were rarely investigated. Nevertheless, dense stands of cacti that dominated large regions in countries such as South Africa certainly caused declines in abundance of native species (Hoffmann, personal communication). Introduction of the Opuntia-feeding pyralid moth Cactoblastis cactorum into the Caribbean region in the 1950s for pasture enhancement, however, damaged - but did not extirpate - some native cacti species on Nevis and St. Kitts (Pemberton and Liu, 2007). This introduction added this pyralid moth into a region near the center of Opuntia biodiversity where it had not formerly occurred, without a non-target risk assessment.

Saltcedars (Tamarix ramosissima, other Tamarix species, and hybrids) infest about 650,000 ha in western North America, primarily along desert rivers where they displace native willow (Salix spp.) and cottonwood (Populus spp.) (Zavaleta, 2000). Fifty rare or endangered species of amphibians, arthropods, birds, fish, reptiles, or plants occur in saltcedar-infested areas (DeLoach and Tracy, 1997). Saltcedar has degraded their habitats through displacement of native vegetation (Lovich et al., 1998), change to physical conditions (Busch and Smith, 1993), loss of food resources (Kennedy and Hobbie, 2004), effects on aquatic invertebrates (Bailey et al., 2001), and water depletion (Davenport et al., 1982). Effects on endangered fish include the loss of shallow sandbar habitat for the Rio Grande silvery minnow (Hybognathus amarus), loss of low velocity nursery habitat for the Colorado pikeminnow (Ptychocheilus lucius), and reduction in water levels in springs supporting desert pupfish (Cyprinodon macularius). In some areas, rare fish were found for the first time only after saltcedar was removed (DeLoach et al., 2000; Kennedy et al., 2005). Introduced leaf-feeding beetles (Diorhabda spp.) have defoliated hundreds of thousands of hectares, and are beginning to kill saltcedar trees (Hudgeons et al., 2007; Carruthers et al., 2008; Deloach et al., 2008; Tracy and Robbins, 2009). If saltcedar tree deaths from biological control agents become widespread, this should significantly improve wildlife habitat, as physical removal of saltcedar is documented to benefit native plants (Lovich and Bainbridge, 1999), reptiles (Bateman et al., 2008), fishes (Kennedy et al., 2005), and birds (Longland and Dudley, 2008). Field assessments of potential non-target risk to native Frankenia species, the taxon identified as potentially at risk from Diorhabda feeding, found no significant impacts under field "worst case" conditions (Dudley and Kazmer, 2005).

Drought and disturbance promote invasion of tumbleweeds (Salsola spp.) in western North American, causing competition with desirable vegetation (Allen, 1982; Brandt and Rickard, 1994; Hrusa and Gaskin, 2008). Tumbleweeds infest large areas in the Carrizo Plain National Monument in southern California (Smith, personal communication). In Death Valley National Park, USA, Salsola paulsenii competes with endangered Eureka Dunes evening primrose (Oenothera californica ssp. eurekensis) and Eureka Valley dune grass (Swallenia alexandrae) (Smith, personal communication). A mite (Aceria salsolae) specific to the genus Salsola has been discovered that reduces plant size by $80 \%$ (Smith et al., 2009) and permission for its release has been requested (Smith, 2005).

In Australia,invasive mesquite shrubs (Prosopis spp.) form extensive, dense groves in some arid and semi-arid rangelands, excluding ground cover, especially in the more mesic areas (van Klinken et al., 2006). In the Pilbara region, the spread of mesquite has been reduced through biological control with a leaf-tying moth (a gelechiid, Evippe sp. \#1) (van Klinken and Campbell, 2009; van Klinken, unpublished data).

In South Africa, the Australian shrub hakea invaded the Southwestern Cape and displaced fynbos (a floristic kingdom with 8700 plant species, 68\% endemic) over large areas (Richardson et al., 1997; Holmes et al., 2000). The introduction of five herbivorous insects attacking the flowers, fruits, and stems (Gordon, 1999; Gordon, personal communication), together with the pathogen Colletotrichum gloeosporioides, caused considerable damage and mortality to $H$. sericea. This complemented mechanical control, resulting in substantial decline of hakea in invaded areas (Esler et al., 2010), benefiting fynbos communities.

\subsection{Coastal areas and sand dunes}

Dunes, coastal shrublands and tidal wetlands are fragile ecosystems that are under threat from invasive plants in many countries. In some instances, exotic plant species were deliberately introduced or extensively planted to stabilize and limit movement of wind-blown sand. The negative consequences of these invasive plants for native biodiversity were eventually recognized and triggered the implementation of biological control programs in several 
countries. Here we discuss four plants and one insect that have seriously affected these early successional habitats: Chrysanthemoides monilifera ssp. rotundata, Asparagus asparagoides, Spartina alterniflora, Acacia cyclops, and the insect Jamella australiae.

Chrysanthemoides monilifera ssp. rotundata (bitou bush), a woody shrub native to South Africa, has invaded over $80 \%$ of the coastline of New South Wales, Australia, in the past century (Thomas and Leys, 2002). Dense stands dominate sand dunes, coastal grasslands, heath, woodlands, and rainforests and drastically alter these communities. Bitou bush out-competes native plants, particularly at the seedling stage (Ens and French, 2008), by exuding allelochemicals (Ens et al., 2009). Its invasion severely alters vegetation structure and richness (Mason and French, 2008) and produces a darker, cooler, moister environment that changes invertebrate assemblages (Lindsay and French, 2006). Bitou bush is the dominant threat to 150 native plant species in 24 coastal plant communities in New South Wales (DEC, 2006). A biological control program initiated in 1987 has established four insect species (Downey et al., 2007), of which the geometrid tip moth Comostolopsis germana and the seed fly Mesoclanis polana are widespread and significantly suppress flowering and seed production (Holtkamp, 2002; Edwards et al., 2009). Modeling suggests, however, that the introduction of foliage-feeding agents will be needed for complete control of the weed (Kriticos et al., 2004).

Asparagus asparagoides (bridal creeper) from South Africa is a major invader of coastal vegetation in temperate Australia (Morin et al., 2006a). It also occurs in inland shrublands, woodlands, and forests. It smothers areas of natural vegetation and severely limits growth of many native plants. In Western Australia, bridal creeperinfested areas had only half as many native plant species as nearby non-invaded areas (Turner et al., 2008a). It is also a threat to four endangered ecological communities in New South Wales - littoral rainforest, river-flat eucalypt forest on coastal floodplains, swampoak floodplain forest, and subtropical coastal floodplain forest (Downey, 2006) and to many native plants, including the orchid Pterostylis arenicola (Sorensen and Jusaitis, 1995) and the shrub Pimelea spicata (Willis et al., 2003). Three biological control agents have been released against bridal creeper in Australia: an undescribed leafhopper (previously referred to as Zygina sp.), the rust fungus Puccinia myrsiphylli, and the leaf beetle Crioceris sp. (Morin and Edwards, 2006; Morin et al., 2006b). The leafhopper and rust fungus have established widely across temperate Australia; the rust appears to be the more effective agent (Morin et al., unpublished data; Turner et al., 2008b). However, dead but persistent rhizomes and tubers in the soil after effective biological control remain an impediment to quick recolonization by native plants (Turner et al., 2006).

Spartina alterniflora (and the foliosa $\times$ alterniflora hybrid), S. anglica, S. patens, and S. densiflora (collectively, "cordgrasses") have invaded intertidal wetlands on the Pacific coast of the USA (Ayres et al., 2004), transforming mudflats into salt marshes and eliminating critical habitat for birds, fish and shellfish. Cordgrasses also outcompete native salt marsh plants in the upper intertidal zone (Daehler and Strong, 1996). In Oregon, cordgrasses invaded native stands of D. cespitosa and Scirpus maritimus (Callaway and Josselyn, 1992). In San Francisco Bay, invasion by a Spartina foliosa $\times$ alterniflora hybrid reduced macrofaunal species richness and increased dominance of subsurface detritus feeders (Neira et al., 2007). In 2000, the planthopper Prokelisia marginata (a common herbivore of $S$. alterniflora in its eastern USA native range) was introduced to Willapa Bay, Washington, to complement chemical and mechanical control (Grevstad et al., 2003). There, the planthopper reduced above-ground biomass of S. alterniflora by $50 \%$ soon after release (Grevstad et al., 2003). One S. alterniflora genotype, however, is tolerant to planthopper feeding and may gradually increase as vulnerable genotypes are suppressed (Garcia-Rossi et al., 2003).
A meta-analysis of effectiveness of cordgrass management techniques concluded that the planthopper was highly effective against S. anglica (causing $92.5 \%$ reduction in density), but was less so against S. alterniflora (18.4\% reduction in density) (Roberts and Pullin, 2008).

Acacia cyclops (rooikrans) is an Australian species invasive in coastal dune systems of South Africa, where it forms impenetrable stands in the lowlands fynbos of the Eastern and Western Cape Provinces (Richardson et al., 1996). Rooikrans is among three invasive species that are most threatening to native plant biodiversity in the Cape Peninsula (Higgins et al., 1999). However, because the plant is valued in some contexts, biological control agents were selected that attack plant reproduction, rather than cause death. The introduced seed-feeding weevil Melanterius cf servulus damages up to $90 \%$ of the seeds (Impson et al., 2004) but has been slow to increase and disperse. The flower-galling midge Dasineura dielsi more rapidly increased in density and spread (Adair, 2005; Impson et al., 2008), but its impact has been more variable between sites and years.

The flatid insect J. australiae, native to north Queensland, invaded south Queensland, where it killed native Pandanus tectorius trees, an ecologically important coastal species. An egg parasitoid, Aphanomerus sp., moved from north to south Queensland, brought the pest under control (Smith and Smith, 2000).

\subsection{Oceanic island communities}

Island biodiversity is not high, but often consists of endemic species derived from mainland immigrants. Many plants imported to islands for human use have escaped cultivation and become damaging environmental pests. Accidental insect introductions to islands frequently occur because of agriculture, movement of plants, trade, and tourism. About 20 exotic arthropod species invade the Hawaii Islands each year, and many of these become serious pests on native vegetation (Messing and Wright, 2006). Several human-assisted invasions have been linked to the species extinctions (Elton, 1958). Here we discuss the role of biological control in conserving the endemic biodiversity of islands.

\subsubsection{Invasive insects attacking native plants}

Invasive herbivorous insects are frequently transported to islands on introduced ornamentals or crop plants or they may hitch-hike unnoticed on cargo. Invasive insects can be highly damaging to native plants as well as to native invertebrate and vertebrate species that depend of them for refuge or food. Biological control of exotic insects attacking native flora is an extension of the use of biological control against arthropod pests of crops and ornamental plants, and its use is increasing.

2.7.1.1. Scales. A large number of scales, especially in the Diaspididae and Coccidae, have been moved around the world through the transportation of plants. Small founding population size frequently results in key parasitoids of invading scales being unrepresented in the material transported to new locations, allowing scale population explosions. Examples of the biodiversity impacts of invasive scales on tropical forests were discussed above for Australia. The same processes also occur on islands.

In 1991, the South American scale Orthezia insignis was recorded on St. Helena in the south Atlantic (Fowler, 2004). By 1992, the scale was killing endangered, endemic gumwood trees (Commidendrum robustum) (Fowler, 2004). The lady beetle Hyperaspis pantherina was released in 1993 (Booth et al., 1995; Fowler, 2004) and by 1995 scale density had decreased by $97 \%$ and tree death due to scale infestations no longer occurred (Fowler, 2004). Biological control of 0 . insignis saved the remnant gumwood stands, and removed the scale's threat to the three other Commidendrum spp. (Fowler, 
2004), a genus which comprises a significant part of St. Helena's remaining native trees (Cronk, 1989). Additional conservation benefits included prevention of damage to the newly restored Millenium Forest (St. Helena National Trust, 2009), prevention of harm to natural regeneration of Commidendrum rugosum on $50 \%$ of St. Helena (Fowler, 2004; Anonymous, 2009; Joint Nature Conservation Committee, 2009), and the preservation of several endemic weevils (e.g., Nesiotes spp.) associated with gumwoods (Pearce-Kelly, personal communication in Booth et al., 1995; Joint Nature Conservation Committee, 2009).

Icerya scales (Margarodidae) have invaded various islands - the Galápagos, the Seychelles, Ascension, and various parts of Micronesia - and attacked native plants. The best known Icerya species is the polyphagous cottony cushion scale, Icerya purchasi, which in addition to being a major citrus pest (Hale, 1970; Ben-Dov et al., 2009), damages many native island plants, often ones with restricted distributions (Cronk, 1980; Causton, 2001; Causton et al., 2006). The scale also indirectly threatens rare insects that depend on these plants for food or shelter (e.g., Roque-Albelo, 2003). It has been repeatedly controlled by the specialized predatory coccinellid Rodolia cardinalis (Caltagirone and Doutt, 1989), which develops exclusively on monophlebine (Hemiptera: Margarodidae) scales, principally Icerya species (Causton, 2001; Causton et al., 2004). On the Galápagos, I. purchasi attacked 16 threatened plant species, as well as many other native plants (Causton, 2001, 2003). Scale-induced mortality of one rare plant, Darwiniothamnus tenuifolius, was linked to local population extirpations of three moths (Roque-Albelo, 2003). Important mangrove habitats were damaged by heavy scale infestations (Causton, 2003). Rodolia cardinalis was released on ten Galápagos islands in 2002 to protect threatened native plants (Causton et al., 2006; Causton, unpublished data). Exclusion experiments and post-introduction monitoring were conducted on heavily infested stands of white mangrove (Laguncularia racemosa) in Puerto Ayora, Santa Cruz Island, and data showed a marked decrease in scale density within 12 weeks of liberating $R$. cardinalis (Calderon Alvarez, 2002). More extensive evaluations of the impacts of this predator were begun in 2009. In the South Atlantic, $R$. cardinalis was released on Ascension Island in 1976 to control cottony cushion scale on ornamental plants (Cronk, 1980). The beetle also provided protection for the rare endemic spurge Euphorbia origanoides, which was suffering population decline due to scale attack (Cronk, 1980; Fowler, 2004). By 1995 scale density on the island was low, and the scale was completely absent on sampled E. origanoides populations, including one population specifically examined by Cronk (1980) (Fowler, unpublished data). Icerya purchasi was also absent on E. origanoides when the plant was re-surveyed in 1997 (Ashmole and Ashmole, 1997) (see Plate 2).

Other species of Icerya have threatened island plants, including Icerya seychellarum in the Seychelles and Icerya aegyptiaca on various coral atolls in the western Pacific (Waterhouse, 1993). Icerya seychellarum invaded Aldabra in the Seychelles around 1968 and quickly became damaging (Hill and Newbery, 1980). By the 1980s, native plant species such as Avicennia marina, Euphorbia pyrifolia, Ficus lutea, Scaevola sericea, and the endemic Sideroxylon inerme ssp. cryptophlebium were heavily damaged (Newbery and Hill, 1985; Newbery, 1988; Gery, 1991). The rare native species Maillardia montana and Psychotria pervillei were on the point of extinction from $I$. seychellarum and other stresses (Friedmann, 1994). Rodolia chermesina was released on Aldabra in 1989 to control I. seychellarum (Gery, 1991). Monitoring for 5 years following the release of $R$. chermesina showed reduced scale density and recuperation of the affected plant species (Johnson and Threadgold, 1999; Beaver, personal communication). In the western Pacific, destructive populations of I. aegyptiaca developed on various coral atolls including Kiribati, Federated States of Micronesia, the Mariannas, and Marshall and Wake Islands (Beardsley, 1955;
Waterhouse, 1993). Native plants attacked included Casuarina equisetifolia, Calophyllum inophyllum, and the sand dune plants Scaevola koenigii and Scaevola frutescens (Manser, 1974; Maddison, 1976). From 1994 to 1999, CSIRO in Australia introduced Rodolia limbata into infested western Pacific atolls and within 2 years, control was achieved on atolls of the Federated States of Micronesia, Kiribati and Marshall Islands (Brancatini and Sands, 1997; Sands et al., 1999).

On Guam, an invasive cycad-attacking diaspidid scale, Aulacaspis yasumatsui, destroyed much of the island's native cycad forests. The scale is native to Thailand where it is a minor pest kept at low densities by parasitoids (Tang et al., 1997). In 2003, the scale was detected on ornamental cycads at two of Guam's hotels. It quickly spread into wild populations of Micronesia's endemic cycad, Cycas micronesica, which is the dominant tree-sized plant in Guam's limestone forests and a keystone species of the community. This scale, in combination with two other cycad-feeding invasive species (the lycaenid Chilades pandava and the tineid leafmining moth Erechthias sp. [Moore et al., 2005; Marler and Muniappan, 2006]), caused cycad death rates to reach $60-90 \%$ in some areas in 2004-2008. This high mortality led conservationists to place C. micronesica on the IUCN Red List (Marler, 2006). Biological control began after surveys in Guam found no attack of the scale by local parasitoids or predators. The aphelinid parasitoid Coccobius fulvus was introduced in 2005 from Florida (where it had suppressed the target scale) (Weise et al., 2005), but it failed to establish. The coccinellid $R$. lophanthae was introduced from $\mathrm{Ha}-$ waii, established widely, and suppressed the scale on mature cycads. It was also established on Rota, Koror, and Babeldaup as the scale spread in Micronesia. However, this predator did not suppress the scale adequately on seedlings, which continued to die at elevated rates. Further biological control introductions, likely of parasitoids, are needed to protect seedlings and secure the future of Guam's cycad limestone forests.

2.7.1.2. Gall wasps. Like scales, galling insects are tightly associated with plants and may be moved with their hosts to new regions, where they may spread to native plants. The plant genus Erythrina has 112 species in tropical or warm temperate regions (Neill, 1988), several of which are on the IUCN Endangered Species List and are threatened by invasion of the gall wasp Quadrastichus erythrinae. In Hawaii, this eulophid wasp devastated stands of the wiliwili tree (Erythrina sandwicensis), causing severe tissue distortion, defoliation, and death (Kim et al., 2004; Yang et al., 2004). The wiliwili tree is an endemic keystone species in lowland Hawaiian forest, one of the most endangered ecosystems in the world (http:// www.hear.org). The invader's area of origin is not certain (Gramling, 2005; Messing et al., 2009), but natural enemies surveys were conducted in Africa, where the parasitoid Eurytoma erythrinae was found attacking Quadrastichus spp. (Gates and Delvare, 2008). This parasitoid was evaluated in quarantine and released in Hawaii. Initial observations showed ready establishment, rapid spread, and high impact of E. erythrinae. A second parasitoid (Aprostocetus sp.) is also under study.

2.7.1.3. Vectors of plant pathogens. Certain invasive insects, especially leafhoppers and aphids, have the potential to introduce or more efficiently vector plant pathogens to native plants. The cicadellid leafhopper Homalodisca vitripennis (glassy-winged sharpshooter) is a polyphagous xylem feeder that vectors the plant pathogenic bacterium Xylella fastidiosa. Native to parts of the USA and Mexico, this leafhopper invaded French Polynesia (in 1999), Hawaii (2004), Easter Island (2005), and the Cook Islands (2007), most likely via the movement of ornamental plants. In the absence of the mymarid egg parasitoid Gonatocerus ashmeadi, dense leafhopper populations developed and retarded plant growth and fruit 

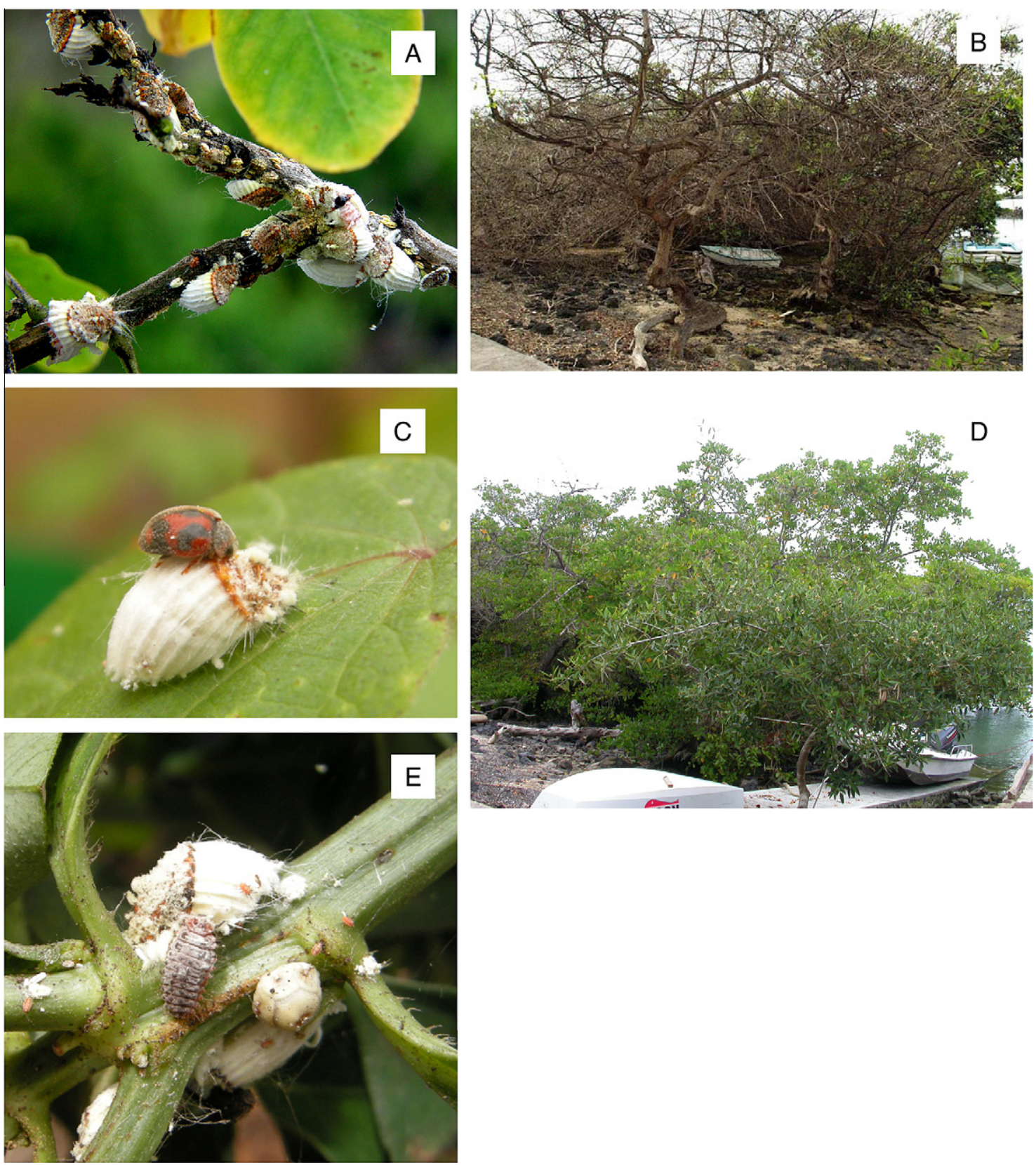

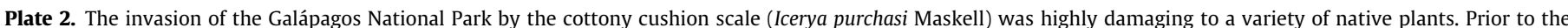

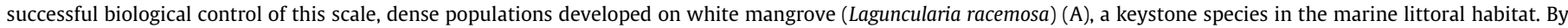

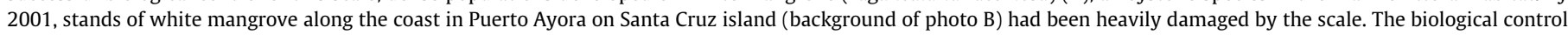

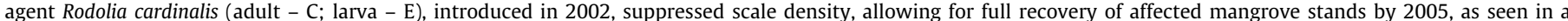

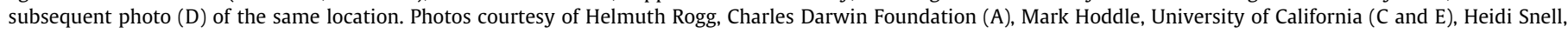
Visual Escapes.smugmug.com (B), and Charlotte Causton, Charles Darwin Foundation (D).

yields, and produced copious watery excreta (Grandgirard et al., 2006). Nymphs and adult leafhoppers were toxic to some generalist predators, in particular native spiders (Suttle and Hoddle, 2006). Following risk assessment studies (Grandgirard et al., 2007), G. ashmeadi was released into French Polynesia and suppressed the leafhopper in all archipelagos within 7-10 months (Grandgirard et al., 2008; Petit et al., 2009). Suppression of leafhopper density protected native spiders and reduced the likelihood of infection of native plants with $X$. fastidiosa.

\subsubsection{Invasive plants}

Islands have been extensively invaded by introduced plants. Some of these have been subject to weed biological control, espe- cially in Hawaii and New Zealand. Examples from small islands include miconia and gorse.

Miconia calvescens, a small, broad-leafed tree from Central and South America, escaped cultivation and established widely on Pacific islands, including Hawaii and Tahiti. It invaded natural forests and formed dense monospecific stands that were damaging to native vegetation (Meyer and Florence, 1996; Medeiros et al., 1997; Meyer, 1998). The fungus Colletotrichum gloeosporioides forma specialis miconiae from Brazil is specific to M. calvescens (Killgore et al., 1999). It was released in Tahiti in 2000, where it established from sea level to $1400 \mathrm{~m}$ and caused partial defoliation of miconia canopy trees in mesic and wet forests. Defoliation reached $47 \%$ and this allowed increases in cover and diversity of native vegetation 
(Meyer et al., 2008, 2009). The fungus was also introduced into Hawaii, but had little impact, apparently due to higher temperatures. Additional agents, particularly insects, are under investigation (e.g., Seixas et al., 2004; Badenes-Perez et al., 2007).

Gorse is a thorny European shrub introduced into several countries, including Chile, where in the archipelago of Chiloé it became invasive on at least 10 islands (Norambuena et al., 2007). On Chiloé (and associated islands) releases have been made of the seed-feeding brentid $E$. ulicis and the spider mite T. lintearius, both of which established on three islands (Norambuena, unpublished data).

\section{Protecting resources obtained from natural ecosystems}

Many early biological control projects were started to protect resources harvested from wildlands, especially wood, forage, and water. Others were begun to protect the use of rivers for hydroelectric power generation, navigation, or fishing. Most of the species reviewed in the following section were previously discussed in regard to their impacts on biodiversity and here we elaborate further on the economic losses of natural resources caused by these invasive species. Details of their biological control, presented in the previous section, are summarized in Table 1 (insects) or Table 2 (plants). Values given below are in United States dollars.

\subsection{Wood products from native forests}

Damaging insects can reduce the ability of native forests to yield wood products. Some forest pests are native species, and as such are outside the scope of this article. Also, some invasive insects are serious pests in forest plantations, which are also not covered here, even though many have been successful targets of classical biological control. We restrict our review to invasive species that have reduced the productivity of native forests or increased mortality of key timber species. Most of the examples discussed are from North America, which has both extensive native forests and many invasive forest pests. Other regions have either been less often invaded by pests of native forests, or rely heavily on plantation forestry, whose biological control projects are outside the scope of this article. In North America, five species introduced pine sawfly $(D$. similis), European spruce sawfly (G. hercyniae), larch casebearer (C. laricella), winter moth (O. brumata), and gypsy moth (L. dispar) - have been wholly or partly controlled with biological control. Two other important biological control projects targeted at emerald ash borer (A. planipennis) and hemlock woolly adelgid (A. tsugae) are in progress (Table 1 ).

\subsubsection{Introduced sawflies and moths}

All of the species discussed in this section have been successfully suppressed with biological control in all or part of the invaded range (Table 1). The introduced pine sawfly and European spruce sawfly invaded North America about 1914-1922 (Coppel et al., 1974; Drooz, 1985) and spread widely, attacking pines and spruce, respectively. By 1981, the introduced pine sawfly defoliated 2.2 million ha of pine forests in Virginia and North Carolina (Drooz et al., 1979; Ghent et al., 1982), but caused little tree death. In 1935, European spruce sawfly defoliated 1.5 million ha spruce in the Gaspé Peninsula, New Brunswick, Canada, with high tree mortality in some stands. At its peak, the European spruce sawfly infested $363,000 \mathrm{~km}^{2}$ of forest (see Van Driesche et al., 1996).

Larch casebearer invaded Massachusetts about 1886 and spread into the Canadian maritime provinces and west to British Columbia (Drooz, 1985), tracking larch distributions. In eastern North America, outbreaks occurred from the early 1900s (Felt and Bromely, 1932) through the 1950s (Webb and Quednau, 1971), eventually ceasing due to introduced parasitoids. Outbreaks in Idaho and Ore- gon occurred from 1957 until larch casebearer was suppressed by natural enemies (Ryan, 1990). Before its biological control, this moth was among the top two pests of western larch (Schmidt et al., 1976). Repeated defoliation of larch in northern Idaho reduced tree growth by $80 \%$, but growth returned to normal after successful biological control (Long, 1988).

Winter moth invaded the Canadian Maritimes in the 1930s and later British Columbia and Massachusetts. This polyphagous species feeds on a great range of deciduous trees, and repeated defoliation causes thin tops, dead branches, and tree death (Drooz, 1985). In Nova Scotia in a 1950 s outbreak, damage to Q. rubra was greatest on trees with early bud break (due to better synchrony with the caterpillars), and in the most defoliated plots $40 \%$ of oaks died over several years (Embree, 1967). The infestation in eastern Canada peaked in 1954-1956 when it covered 60\% of Nova Scotia, killing up to $100 \%$ of oaks in areas with greatest defoliation (Cuming, 1961). In 1977, a separate infestation in British Columbia covered $120 \mathrm{~km}^{2}$ (Gillespie et al., 1978). A third infestation - in Massachusetts - defoliated 60,325 ha in 2003 (Anonymous, 2004). Damage from winter moth includes loss of oak lumber due to tree death, and loss of quality white pine regeneration in the absence of over story shade (i.e., increased forking from more oviposition by Pissodes strobi) (Embree, 1965).

Gypsy moth was imported to Massachusetts by an amateur entomologist in 1869 and escaped. It established and spread throughout many oak-dominated forests of the northeastern USA, eventually reaching Ontario, Michigan, and Virginia. The most intense defoliation occurred in 1911-1922 in New England (Houston, 1981 ) and the largest outbreaks were in 1980-1982 and 19891991 (10.7 and 5.8 million ha defoliated, respectively) (USDA Forest Service website). Depending on tree health and site conditions, defoliated oaks suffered varying degrees of mortality. In 19111931 in eastern New England, 35\% of oaks in poor condition died from a single defoliation, while $7 \%$ of trees in good condition did so (Campbell and Sloan, 1977). Deaths occurred up to several years after defoliation.

\subsubsection{Tree-killing borers and adelgids}

Biological control projects against the two species discussed here are in progress (Table 1 ). By 2009, the emerald ash borer (Coleop.: Buprestidae) infested eleven US states and several Canadian provinces (http://www.emeraldashborer.info/). Infestations are currently expanding annually by $16-32 \mathrm{~km}$ due to adult flight, and new infestations are being created by long distance movement of fire wood or live infested trees. In Michigan, where 18.2 million cubic meters ( 7.7 billion board feet) of ash timber are harvested annually (USDA APHIS, 2007), more than 30 million ash (Fraxinus spp.) trees had been killed (Poland and McCullough, 2006; EAB, 2009). The loss to date in Michigan is estimated at 42.5 million cubic meters of wood (18 million board feet) valued at \$4-9 million (Michigan Department of Natural Resources website). Many Michigan stands have lost up to $100 \%$ of their large ash trees. Nationally, US timberlands contain an estimated 8 billion ash trees, $7.5 \%$ by volume of all hardwoods. Thus future losses, given spread to the pest's ecological limits, could increase greatly (see www. aphis.usda.gov/plantpest/emerald_ash_borer).

Hemlock woolly adelgid invaded the USA from Japan (Havill et al., 2006) and has widely degraded eastern hemlock forests. Lumbering of eastern hemlock is modest due to its lower wood quality compared to other softwoods, but about 1.2 million cubic meters of wood (500 million board feet) are harvested annually (Brisbin et al., 1970; Howard et al., 2000). Hemlock bark is used for mulch (Howard et al., 2000) and its wood for log home construction, pulpwood, and composite materials (Winn and Araman, 2005). Since the 1950 s, hemlock woolly adelgid has spread over $20-30 \%$ of eastern hemlock's range. In New Jersey in 1984 (before hemlock woolly 
Table 1

Status of classical biological control programs for invasive insects mentioned in the text.

\begin{tabular}{|c|c|c|c|c|c|c|c|c|c|c|}
\hline & \multirow[t]{2}{*}{ Target species } & \multirow[t]{2}{*}{ Host plant } & \multicolumn{3}{|c|}{ Nature of Impacts $(X)^{a}$} & \multicolumn{3}{|c|}{ Outcome $(\boldsymbol{} \boldsymbol{\sim})^{\mathrm{b}}$} & \multirow[t]{2}{*}{ Location/comments } & \multirow[t]{2}{*}{ References } \\
\hline & & & Biodiv. & Prod. & $\begin{array}{l}\text { Eco. } \\
\text { Sv. }\end{array}$ & C & $\mathrm{P}$ & IP & & \\
\hline 1 & $\begin{array}{l}\text { Adelges tsugae Annand (hemlock woolly } \\
\text { adelgid) }\end{array}$ & Hemlock & $\mathrm{x}$ & $\mathrm{x}$ & $\mathrm{x}$ & & & $\boldsymbol{r}$ & Eastern USA & $\begin{array}{l}\text { Evans (2002), Cheah and McClure (1998), } \\
\text { McClure et al. (2000), Lu and Montgomery (2001), } \\
\text { Montgomery et al. (2002), Zilahi-Balogh et al. (2002, } \\
\text { 2003) }\end{array}$ \\
\hline 2 & Agrilus planipennis (emerald ash borer) & Ash & $\mathrm{X}$ & $\mathrm{x}$ & & & & $\boldsymbol{\nu}$ & $\begin{array}{l}\text { Agents confirmed established and impact being } \\
\text { evaluated }\end{array}$ & Bauer et al. (2007) \\
\hline 3 & Aulacaspis yasumatsui (cycad scale) & Cycads & $\mathrm{x}$ & & & & $r$ & & $\begin{array}{l}\text { Guam; control effective only on mature plants, not } \\
\text { seedlings }\end{array}$ & $\begin{array}{l}\text { Ross Miller and Aubrey Moore (personal } \\
\text { communication) }\end{array}$ \\
\hline 4 & Cinara cupressivora (cypress aphid) & Cupressaceae & $\mathrm{x}$ & $\mathrm{x}$ & & & $\boldsymbol{\nu 1}$ & & $\begin{array}{l}\text { East/South Africa } \\
1-\text { control due to several factors }\end{array}$ & \\
\hline 5 & Ceroplastes destructor (white wax scale) & Diverse plants & $\mathrm{X}$ & & & $\boldsymbol{r}$ & & & Queensland, Australia & Sands et al. (1986) \\
\hline 6 & Ceroplastes rubens (pink wax scale) & Diverse plants & $\mathrm{x}$ & & & & $\boldsymbol{} \sim 1$ & & $\begin{array}{l}\text { Queensland, Australia } \\
1 \text { - controlled on some native hosts but not others }\end{array}$ & Waterhouse and Sands (2001) \\
\hline 7 & Coleophora laricella (larch case bearer) & Larch & & $\mathrm{x}$ & & $\boldsymbol{r}$ & & & North America & Webb and Quednau (1971), Ryan (1990), Long (1988) \\
\hline 8 & Dendroctonus micans (spruce beetle) & Spruce & $\mathrm{X} 1$ & $\mathrm{X} 2$ & & $r$ & & & $\begin{array}{l}1 \text { - Caucasus region } \\
2 \text { - Western Europe and Caucasus region }\end{array}$ & Grégoire (1988), Fielding and Evans (1997) \\
\hline 9 & Diprion similis (pine sawfly) & Pine & & $\mathrm{x}$ & & $\boldsymbol{\nu}$ & & & North America & McGugan and Coppel (1962) \\
\hline 10 & Dryocosmus kuriphilus (chestnut gall wasp) & Chestnut & $\mathrm{x}$ & $\mathrm{x}$ & & $\nu 1$ & & $\boldsymbol{r}^{2}$ & $\begin{array}{l}1 \text { - Japan, USA } \\
2 \text { - Europe }\end{array}$ & $\begin{array}{l}\text { Moriya et al. (2003), Cooper and Rieske (2007), } \\
\text { Quacchia et al. (2008) }\end{array}$ \\
\hline 11 & Gilpinia hercyniae (European spruce sawfly) & Spruce & & $\mathrm{x}$ & & $\boldsymbol{r}$ & & & North America & Magasi and Syme (1984) \\
\hline 12 & $\begin{array}{l}\text { Homalodisca vitripennis (glassy-winged } \\
\text { sharpshooter) }\end{array}$ & Diverse plants & $\mathrm{x}$ & & & $\boldsymbol{\sim} 1$ & & $\boldsymbol{\nu} 2$ & $\begin{array}{l}1 \text { - complete control in Tahiti } \\
2 \text { - project in progress in California, } \\
\text { but control developing slowly }\end{array}$ & Grandgirard et al. (2008), Petit et al. (2009) \\
\hline 13 & Icerya aegyptiaca & Diverse plants & $\mathrm{X}$ & & & $\boldsymbol{r}$ & & & $\begin{array}{l}\text { Kiribati, Federated States of Micronesia, the } \\
\text { Mariannas, Marshall, and Wake Islands }\end{array}$ & Brancatini and Sands (1997), Sands et al. (1999) \\
\hline 14 & Icerya purchasi (cottony cushion scale) & Diverse plants & $\mathrm{x}$ & & & $\boldsymbol{\sim} 1$ & & $\boldsymbol{\nu} 2$ & $\begin{array}{l}1 \text { - control complete on Ascension Island } \\
2 \text { - control being evaluated in Galapagos, } \\
\text { but appears effective }\end{array}$ & $\begin{array}{l}\text { Causton et al. (2006), Causton (unpublished data), } \\
\text { Calderon Alvarez (2002), Fowler (unpublished data), } \\
\text { Ashmole and Ashmole (1997) }\end{array}$ \\
\hline 15 & Icerya seychellarum & Diverse plants & $\mathrm{x}$ & & & $\boldsymbol{r}$ & & & Seychelles & $\begin{array}{l}\text { Johnson and Threadgold (1999), Beaver (personal } \\
\text { communication) }\end{array}$ \\
\hline 16 & Jamella australiae & $\begin{array}{l}\text { Pandanus } \\
\text { tectorius }\end{array}$ & $\mathrm{x}$ & & & $\boldsymbol{r}$ & & & Southern Queensland, Australia & Smith and Smith (2000) \\
\hline 17 & Lymantria dispar (gypsy moth) & Oak & $\mathrm{x}$ & $\mathrm{x}$ & & & $r$ & & $\begin{array}{l}\text { Successful control in the core infested } \\
\text { area of New England }\end{array}$ & $\begin{array}{l}\text { Van Driesche et al. (1996, see pp. 85-88), } \\
\text { Webb et al. (1999), Gillock and Hain (2001) }\end{array}$ \\
\hline 18 & Metamasius callizona (bromeliad weevil) & bromeliads & $\mathrm{x}$ & & & & & $\boldsymbol{\nu}$ & Florida (USA) & Frank and Cave (2005), Cave (2008) \\
\hline 19 & Operophtera brumata (winter moth) & Oak & & $\mathrm{x}$ & & $\boldsymbol{\nu 1}^{1}$ & & $\boldsymbol{\nu}^{2}$ & $\begin{array}{l}1 \text { - Nova Scotia, British Columbia } \\
2 \text { - Massachusetts }\end{array}$ & Embree (1971), Embree and Otvos (1984) \\
\hline 20 & $\begin{array}{l}\text { Paratachardina pseudolobata (lobate lac } \\
\text { scale) }\end{array}$ & Diverse plants & $\mathrm{x}$ & & & & & $\boldsymbol{r}$ & Florida (USA) & Pemberton (2003), Schroer et al. (2008) \\
\hline 21 & $\begin{array}{l}\text { Quadrastichus erythrinae (erythrina gall } \\
\text { wasp) }\end{array}$ & Erythrina spp. & $\mathrm{x}$ & & & & & $\boldsymbol{r}$ & $\begin{array}{l}\text { Hawaii; agents being evaluated; one released and } \\
\text { established }\end{array}$ & Gates and Delvare (2008) \\
\hline
\end{tabular}

a Biodiv. (effects on biodiversity), Prod. (loss of products produced by natural ecosystems), Eco. Sv. (loss of ecosystem services)

b Degree of control achieved: C - complete control, P - partial control, IP - in progress. 
Table 2

nvasive plants status of classical biological control programs for invasive plants mentioned in the text

\begin{tabular}{|c|c|c|c|c|c|c|c|c|c|}
\hline & \multirow[t]{2}{*}{ Target species } & \multicolumn{3}{|c|}{$\begin{array}{l}\text { Nature of impacts } \\
(\mathrm{X})^{\mathrm{a}}\end{array}$} & \multicolumn{3}{|c|}{ Outcome $(\boldsymbol{} \sim)^{\mathrm{b}}$} & \multirow[t]{2}{*}{ Location/comments } & \multirow[t]{2}{*}{ References } \\
\hline & & Biodiv. & Prod. & $\begin{array}{l}\text { Eco. } \\
\text { Sv. }\end{array}$ & $C$ & $\mathrm{P}$ & IP & & \\
\hline 1 & Acacia cyclops (rooikrans) & $\mathrm{x}$ & & & & & $\boldsymbol{\nu}$ & Coastal dunes of South Africa; $90 \%$ seed damage & Impson et al. (2004) \\
\hline 2 & Acacia longifolia (long leafed wattle) & $\mathrm{x}$ & $\mathrm{x}$ & $\mathrm{X}$ & $\boldsymbol{r}$ & & & South Africa, especially the fynbos region & Dennill et al. (1999), Moran et al. (2005) \\
\hline 3 & $\begin{array}{l}\text { Acacia nilotica subsp. indica (prickly } \\
\text { acacia) }\end{array}$ & $\mathrm{x}$ & $\mathrm{x}$ & $\mathrm{x}$ & & & $\boldsymbol{r}$ & Australia, especially Mitchell grass downs & Radford et al. (2001), Palmer et al. (2007) \\
\hline 4 & Acacia pycnantha (golden wattle) & $\mathrm{x}$ & $\mathrm{x}$ & $\mathrm{x}$ & $\boldsymbol{\nu}$ & & & South Africa, especially the fynbos region & Moran et al. (2005) \\
\hline 5 & Acacia saligna (Port Jackson willow) & $\mathrm{x}$ & $\mathrm{x}$ & $\mathrm{x}$ & $\boldsymbol{\nu}$ & & & South Africa, especially the fynbos region & Moran et al. (2005) \\
\hline 6 & Ageratina riparia (mist flower) & $\mathrm{x}$ & & & $\boldsymbol{r}$ & & & Hawaii and New Zealand & $\begin{array}{l}\text { Trujillo (2005), Barton et al. (2007), Landcare Research } \\
\text { (unpublished data) }\end{array}$ \\
\hline 7 & Ailanthus alitissima (tree of heaven) & $\mathrm{x}$ & & & & & $\boldsymbol{\nu}$ & Eastern USA & Ding et al. (2006), Kok et al. (2008) \\
\hline 8 & Alliaria petiolate (garlic mustard) & $\mathrm{x}$ & & & & & $\boldsymbol{r}$ & $\begin{array}{l}\text { Northeast and north central USA; agents under } \\
\text { evaluation }\end{array}$ & Blossey et al. (2001a) \\
\hline 9 & $\begin{array}{l}\text { Alternanthera philoxeriodes (alligator } \\
\text { weed) }\end{array}$ & $\mathrm{x}$ & $\mathrm{x}$ & & $\boldsymbol{r}$ & $\boldsymbol{r}$ & & $\begin{array}{l}\text { USA, Australia, New Zealand, and China; floating } \\
\text { infestations generally controlled but terrestrial } \\
\text { populations on edges of water bodies still a problem }\end{array}$ & $\begin{array}{l}\text { Coulson (1977), Julien (1981), Julien and Griffiths } \\
\text { (1998), Sainty et al. (1998) }\end{array}$ \\
\hline 10 & Arundo donax (giant reed) & $\mathrm{x}$ & $\mathrm{x}$ & $\mathrm{x}$ & & & $\boldsymbol{r}$ & $\begin{array}{l}\text { Southwestern USA, especially Texas; first agents (gall } \\
\text { wasp and armored scale) released in } 2009\end{array}$ & $\begin{array}{l}\text { Tracey and DeLoach (1998); Goolsby (personal } \\
\text { communication) }\end{array}$ \\
\hline 11 & $\begin{array}{l}\text { Asparagus asparagoides (bridal } \\
\text { creeper) }\end{array}$ & $\mathrm{x}$ & & & & & $\boldsymbol{\nu}$ & $\begin{array}{l}\text { Coastal areas of temperate Australia; little control to } \\
\text { date }\end{array}$ & Morin et al. (unpublished data), Turner et al. (2008b) \\
\hline 12 & Anredera cordifolia (Madeira vine) & $\mathrm{x}$ & & & & & $\boldsymbol{\nu}$ & Coastal eastern Australia, South Africa; agent surveys underway & Cagnotti et al. (2007), van der Westhuizen (2006) \\
\hline 13 & Azolla filiculoides (red fern) & $\mathrm{x}$ & & & $\boldsymbol{\nu}$ & & & South Africa & McConnachie et al. (2004) \\
\hline 14 & $\begin{array}{l}\text { Centaurea diffusa and C. stoebe } \\
\text { (diffuse and spotted knapweeds) }\end{array}$ & $\mathrm{x}$ & $\mathrm{x}$ & & & $r$ & & Western North America & $\begin{array}{l}\text { Smith (2004), Story et al. (2000, 2006, 2008), Seastedt } \\
\text { et al. (2007), Myers et al. (2009) }\end{array}$ \\
\hline 15 & $\begin{array}{l}\text { Centaurea solstitialis (yellow } \\
\text { starthistle) }\end{array}$ & $\mathrm{x}$ & $\mathrm{x}$ & & & & $\boldsymbol{r}$ & $\begin{array}{l}\text { Western North America; plant densities have not yet } \\
\text { been reduced in most locations, but declines have } \\
\text { occurred in Oregon and California }\end{array}$ & $\begin{array}{l}\text { Gutierrez et al. (2005), Smith (2007), Pitcairn et al. } \\
\text { (2005) }\end{array}$ \\
\hline 16 & Chromolaena odorata (Siam weed) & & $\mathrm{x}$ & $\mathrm{x}$ & & $\boldsymbol{r}$ & $\boldsymbol{r}^{2}$ & $\begin{array}{l}1-\text { significant control in Papua New Guinea and East } \\
\text { Timor of one biotype } \\
2-\text { no control yet of second biotype in South Africa }\end{array}$ & $\begin{array}{l}\text { Day and Bofeng (2007), Zachariades et al. (2009), Day } \\
\text { (personal communication) }\end{array}$ \\
\hline 17 & $\begin{array}{l}\text { Chrysanthemoides monilifera ssp. } \\
\text { Rotundata (bitou bush) }\end{array}$ & $\mathrm{x}$ & & & & $r$ & & $\begin{array}{l}\text { Coastline of New South Wales, Australia; flowering and } \\
\text { seed production widely suppressed }\end{array}$ & Holtkamp (2002), Edwards et al. (2009) \\
\hline 18 & Cryptostegia grandiflora (rubber vine) & $\mathrm{x}$ & $\mathrm{x}$ & & & $\boldsymbol{r}$ & & $\begin{array}{l}\text { Dry tropics of Australia; control achieved in droughty } \\
\text { areas }\end{array}$ & $\begin{array}{l}\text { Evans and Tomley (1994), Mo et al. (2000), Vogler and } \\
\text { Lindsay (2002) }\end{array}$ \\
\hline 19 & Dioscorea bulbifera (air potato) & $\mathrm{x}$ & & & & & $\boldsymbol{\nu}$ & Florida, USA; petition for agent release approved & Pemberton (2009) \\
\hline 20 & Eichhornia crassipes (waterhyacinth) & $\mathrm{x}$ & $\mathrm{x}$ & & $\boldsymbol{r}$ & $\boldsymbol{r}$ & & $\begin{array}{l}\text { Southern USA, Mexico, East and West Africa, India, and } \\
\text { other warm regions; complete control in many tropical } \\
\text { areas; partial control in cooler regions }\end{array}$ & $\begin{array}{l}\text { Beshir and Bennett (1985), Center et al. (2002), Coetzee } \\
\text { et al. (2009) }\end{array}$ \\
\hline 21 & Euphorbia esula (leafy spurge) & $\mathrm{x}$ & $\mathrm{x}$ & & & $\boldsymbol{r}$ & & Northern prairies of North America; complete control in many areas & $\begin{array}{l}\text { Cornett et al. (2006), Cline et al. (2008), Samuel et al. } \\
\text { (2008) }\end{array}$ \\
\hline 22 & Fallopia japonica (Japanese knotweed) & $\mathrm{x}$ & & & & & $\boldsymbol{\nu}$ & United States and United Kingdom; first agent approved for release & Shaw et al. (2009) \\
\hline 23 & Hakea sericea (hakea) & $x$ & & & $r$ & & & $\begin{array}{l}\text { South Africa (fybos of Cape region); control achieved in } \\
\text { combination with mechanical control }\end{array}$ & $\begin{array}{l}\text { Gordon (1999), Gordon (personal communication), } \\
\text { Esler et al. (2010) }\end{array}$ \\
\hline 24 & Hydrilla verticillata (hydrilla) & $\mathrm{x}$ & & & & $\boldsymbol{r}$ & $\boldsymbol{r}$ & Southern USA; partial control in a few areas & $\begin{array}{l}\text { Balciunas et al. (2002), Grodowitz (personal } \\
\text { communication) }\end{array}$ \\
\hline
\end{tabular}

(continued on next page) 
Table 2 (continued)

\begin{tabular}{|c|c|c|c|c|c|c|c|c|c|}
\hline & \multirow[t]{2}{*}{ Target species } & \multicolumn{3}{|c|}{$\begin{array}{l}\text { Nature of impacts } \\
(\mathrm{X})^{\mathrm{a}}\end{array}$} & \multicolumn{3}{|c|}{ Outcome $(\boldsymbol{\nu})^{\mathrm{b}}$} & \multirow[t]{2}{*}{ Location/comments } & \multirow[t]{2}{*}{ References } \\
\hline & & Biodiv. & Prod. & $\begin{array}{l}\text { Eco. } \\
\text { Sv. }\end{array}$ & C & $\mathrm{P}$ & IP & & \\
\hline 25 & Hypericum perforatum (St. Johnswort) & $\mathrm{x}$ & $\mathrm{X}$ & & レ & $\boldsymbol{\nu}^{2}$ & & $\begin{array}{l}\text { Western USA, Australia; } 1 \text { - compete control in the USA } \\
2 \text { - partial control in Australia }\end{array}$ & $\begin{array}{l}\text { Huffaker and Kennett (1959), McCaffrey et al. (1995), } \\
\text { Briese (1997) }\end{array}$ \\
\hline 26 & Lantana camara (lantana) & $\mathrm{x}$ & $\mathrm{x}$ & $\mathrm{x}$ & & & $\boldsymbol{\nu}$ & Northern and eastern Australia; limited success in a few areas & Day and Zalucki (2009) \\
\hline 27 & $\begin{array}{l}\text { Lygodium microphyllum (Old World } \\
\text { climbing fern) }\end{array}$ & $\mathrm{x}$ & & $\mathrm{x}$ & & & $\boldsymbol{r}$ & Southern Florida, USA; control is developing at release sites & Boughton and Pemberton (2009) \\
\hline 28 & Lythrum salicaria (purple loosestrife) & $\mathrm{x}$ & & & & $r$ & & Northern USA and adjacent areas of Canada; control in some areas & $\begin{array}{l}\text { Blossey et al. (2001b), Landis et al. (2003), Denoth and } \\
\text { Myers (2005), Grevstad (2006) }\end{array}$ \\
\hline 29 & Macfadyena unguis-cati (cats claw) & $\mathrm{x}$ & & & & & $\boldsymbol{\nu}$ & South Africa, Australia & Dhileepan et al. $(2007 \mathrm{a}, \mathrm{b})$ \\
\hline 30 & Melaleuca quinquenervia (melaleuca) & $\mathrm{x}$ & & $\mathrm{x}$ & $\boldsymbol{r}$ & & & $\begin{array}{l}\text { Southern Florida, USA; control very effective in combination with } \\
\text { mechanical and chemical control of mature plants }\end{array}$ & $\begin{array}{l}\text { Pratt et al. (2005), Center et al. (2007), Rayamajhi et al } \\
(2007,2008,2009) \text {, Tipping et al. (2008, 2009) }\end{array}$ \\
\hline 31 & Miconia calvescens (miconia) & $\mathrm{x}$ & & $\mathrm{x}$ & & $\boldsymbol{\nu 1}$ & $\boldsymbol{\nu 2}$ & $\begin{array}{l}1 \text { - partial control in Tahiti } \\
2 \text { - no control yet in Hawaii }\end{array}$ & $\begin{array}{l}\text { Meyer et al. (2008, 2009), Seixas et al. (2004), Badenes- } \\
\text { Perez et al. (2007) }\end{array}$ \\
\hline 32 & Mimosa pigra (mimosa) & $\mathrm{x}$ & & & & $\boldsymbol{r}$ & & $\begin{array}{l}\text { Northern Australian wetlands; seed production reduced and stands } \\
\text { retreating at edges }\end{array}$ & Heard and Paynter (2009) \\
\hline 33 & Opuntia stricta (prickly pear cactus) & $\mathrm{x}$ & $\mathrm{x}$ & & $\boldsymbol{\nu}$ & & & Australia, South Africa & Dodd (1940) \\
\hline 34 & $\begin{array}{l}\text { Parthenium hysterophorus } \\
\text { (parthenium weed) }\end{array}$ & $\mathrm{x}$ & $\mathrm{X}$ & & & $\boldsymbol{r}$ & & Central Queensland, Australia; control achieved in some areas & Dhileepan (2003) \\
\hline 35 & $\begin{array}{l}\text { Persicaria perfoliate (mile-a-minute } \\
\text { weed) }\end{array}$ & $\mathrm{x}$ & & & & & $r$ & Eastern USA & Hough-Goldstein et al. (2009) \\
\hline 36 & Pistia stratiotes (water lettuce) & $\mathrm{x}$ & $\mathrm{X}$ & & $\boldsymbol{r}$ & & & $\begin{array}{l}\text { Papua New Guinea, Australia; several regions in Africa; and warm parts of } \\
\text { North America }\end{array}$ & $\begin{array}{l}\text { Harley et al. (1990), Mbati and Neuenschwander (2005), } \\
\text { Ajuonu and Neuenschwander (2003), Neuenschwander } \\
\text { et al. (2009), Dray and Center (1992) }\end{array}$ \\
\hline 37 & Prosopis spp. (mesquite) & $\mathrm{x}$ & $\mathrm{x}$ & & & $\boldsymbol{r}$ & & arid parts of Australia; control achieved in the Pilbara region & $\begin{array}{l}\text { van Klinken and Campbell (2009), van Klinken } \\
\text { (unpublished data) }\end{array}$ \\
\hline 38 & Rubus spp. (blackberries) & $\mathrm{x}$ & & & & $\boldsymbol{r}$ & & Chile; reduction in size and competitiveness of plants & Oehrens (1977), Oehrens and Gonzalez (1977) \\
\hline 39 & Salsola spp. (tumble weeds) & $\mathrm{x}$ & $\mathrm{x}$ & & & & $\boldsymbol{\nu}$ & Western USA, especially California & Smith et al. (2009), Smith (2005) \\
\hline 40 & Salvinia molesta (giant salvinia) & $\mathrm{x}$ & $\mathrm{x}$ & & $\boldsymbol{r}$ & & & $\begin{array}{l}\text { Australia, Papua New Guinea, parts of the USA, and parts of Africa, } \\
\text { especially the Congo basin }\end{array}$ & $\begin{array}{l}\text { Room et al. (1981), Thomas and Room (1986a), Mbati } \\
\text { and Neuenschwander (2005), Diop and Hill (2009), } \\
\text { Julien et al. (2009) }\end{array}$ \\
\hline 41 & $\begin{array}{l}\text { Schinus terebinthifolius (Brazilian } \\
\text { peppertree) }\end{array}$ & $\mathrm{x}$ & & & & & $\boldsymbol{\nu}$ & Florida, USA; agents under evaluation & Manrique et al. (2008), Cuda et al. (2009) \\
\hline 42 & Senecio jacobaea (tansy ragwort) & $\mathrm{x}$ & $\mathrm{x}$ & & $\boldsymbol{r}$ & & & Western USA & $\begin{array}{l}\text { McEvoy et al. (1991), Turner and McEvoy (1995), } \\
\text { Coombs et al. (1996), Pemberton and Turner (1990) }\end{array}$ \\
\hline 43 & Sesbania punicea (sesbania) & $\mathrm{x}$ & $\mathrm{x}$ & & $\boldsymbol{\nu}$ & & & South Africa, especially the fynbos region & Hoffmann and Moran (1998) \\
\hline 44 & Solanum viarum (tropical soda apple) & $\mathrm{x}$ & & & & & $\boldsymbol{r}$ & South eastern USA; control achieved at release sites; agent spreading & Medal et al. (2008) \\
\hline 45 & Spartina alterniflora (cordgrass) & $\mathrm{x}$ & & & & $\boldsymbol{r}$ & & $\begin{array}{l}\text { Esturaries of Washington state, USA; widespread reduction of biomass by } \\
50 \%\end{array}$ & Grevstad et al. (2003), Roberts and Pullin (2008) \\
\hline 46 & Tamarix ramosissima (saltcedar) & $\mathrm{x}$ & & $\mathrm{x}$ & & & $\boldsymbol{r}$ & Western USA; control developing around release sites & $\begin{array}{l}\text { Hudgeons et al. (2007), Carruthers et al. (2008), Deloach } \\
\text { et al. (2008), Tracy and Robbins (2009) }\end{array}$ \\
\hline 47 & Triadica sebifera (Chinese tallow tree) & $\mathrm{x}$ & & & & & $\boldsymbol{\nu}$ & South eastern USA; agents under evaluation & Wang et al. (2009) \\
\hline 48 & Ulex europaeus (gorse) & $\mathrm{x}$ & $\mathrm{x}$ & $\mathrm{x}$ & & & $\boldsymbol{r}$ & $\begin{array}{l}\text { Chile, Oregon (USA), Tasmania, Hawaii, New Zealand; some impact in Chile, } \\
\text { Hawaii and Tasmania }\end{array}$ & $\begin{array}{l}\text { Norambuena (1995), Norambuena and Piper (2000), } \\
\text { Davies et al. (2007), Norambuena et al. (2007), Hill et al } \\
\text { (2008) }\end{array}$ \\
\hline 49 & $\begin{array}{l}\text { Vincetoxicum nigrum; Vincetoxicum } \\
\text { rossicum }\end{array}$ & $\mathrm{x}$ & & & & & $\boldsymbol{r}$ & Northeastern USA; surveys for agents in progress & \\
\hline
\end{tabular}

a Biodiv. (effects on biodiversity), Prod. (loss of products produced by natural ecosystems), Eco. Sv. (loss of ecosystem services).

b Degree of control achieved: C - complete control, P - partial control, IP - in progress. 
adelgid), hemlock was the dominant tree on nearly 8000 ha, but in 1994 (after adelgid invasion), 44\% of these trees had experienced moderate to severe defoliation, and $9 \%$ were dead (Royle and Lathrop, 1997). In Connecticut in 1998, all hemlocks in 7 of 8 stands were infested and over $90 \%$ suffered at least $50 \%$ foliar loss (Orwig and Foster, 1998).

\subsection{Forage from natural grasslands}

Invasive plants can reduce the "carrying capacity" (stock supported per ha) of natural grasslands by (1) lowering the quantity or quality of forage, (2) plant toxicity or repellency, or (3) conversion of grasslands to other vegetation.

\subsubsection{Reduction of forage production}

Desirable forage species in native grasslands may be displaced by less palatable invasive plants, especially when grasslands are over-grazed. Grasslands of the western USA have been extensively invaded by toxic or thorny forbs from Europe. More than 300 invasive plants on US rangelands collectively cause an estimated $\$ 2$ billion in annual losses (DiTomaso, 2000). Many of the most important of these are exotic forbs that have been targets of classical biological control (Skinner et al., 2000), such as yellow starthistle, spotted knapweed, leafy spurge, and Russian knapweed (Acroptilon repens). Before biological control-induced change, these plants infested, respectively, 8, 3, 1.0, and 0.6 million ha in the USA (Lajeunesse et al., 1999; Duncan, 2001).

In California, moderate infestations of yellow starthistle (20$31 \%$ total vegetation) reduced carrying capacity for cattle 10 $15 \%$, and heavier infestations reduced forage up to $50 \%$ (Connor, 2003). Although ruminants can digest immature plants, spines on flower heads deter late season grazing (Sheley et al., 1999). In western Montana, spotted knapweed infestations reduced production of the dominant native forage (Pseudoroegneria spicata) up to $88 \%$ (Watson and Renney, 1974), while diffuse knapweed infestations in British Columbia reduced forage up to 90\% (Harris and Cranston, 1979; Strang et al., 1979). Annual losses from both knapweeds were $\$ 600,000$ in Oregon and \$0.9-2.9 million in Idaho (Maddox, 1979; Roché and Roché, 1988). In Montana, the Dakotas, and Wyoming, leafy spurge caused annual losses of $\$ 40.5$ million from reduced forage and control costs (Leitch et al., 1994). Successful biological control of leafy spurge produced direct economic benefits of $\$ 19.1$ million annually, and total benefits of $\$ 58.4$ million (Bangsund et al., 1999). In California in the late 1940s, St. Johnswort infested 900,000 ha, displacing forage and poisoning cattle. Its successful biological control brought about increases of species with forage value (Huffaker and Kennett, 1959; Goeden, 1978). Economic benefits of St. Johnswort's biological control in the USA were not estimated, but annual benefits in Australia, where control was only partial (McCaffrey et al., 1995; Briese, 1997) exceed $\$ 20.6$ million (Paige and Lacey, 2006). In Oregon, biological control of a 1.2 million ha tansy ragwort infestation ended \$5 million in annual losses from reduced pasture productivity and herbicide costs (Coombs et al., 1999).

Australian grasslands have also experienced numerous plant invasions. Opuntia stricta infested 25 million ha in the 1920s and $1930 \mathrm{~s}$ and the infestation was expanding 0.5 million ha/year when the pyralid moth $C$. cactorum was released. Infested land had no economic use (Walton, 2005) until a successful biological control project returned land to productivity due to feeding of the larvae of $C$. cactorum, which facilitated attack by local pathogens in damaged tissues. In the 1980s, Patterson's curse (Echium plantagineum), which is not grazed by cows or horses, infested 5.2 million ha in Australia (Briese et al., 2004). Its biological control provided benefits of $\$ 1.2$ billion (from 1972 to 2005) (Paige and Lacey, 2006). In 1996, musk thistle (Carduus nutans) infested 1.1 million ha of Aus- tralian grassland (Paige and Lacey, 2006). Its subsequent biological control provided $\$ 81.3$ million in benefits (Paige and Lacey, 2006). Biological control of a 2.8 million ha Scotch thistle (Onopordum spp.) infestation provided $\$ 18$ million in benefits (Paige and Lacey, 2006). For a discussion of the non-target impacts in North America of biological control agents released against thistles that are pests in pastures, see Louda and Potvin (1995), Louda et al. (1997, 2003), Louda (1998), and Rose et al. (2005).

\subsubsection{Toxicity or repellency to livestock}

Many invasive plants have toxins or structures that directly harm livestock or deter their grazing. Spotted and diffuse knapweeds, yellow starthistle, leafy spurge, Russian knapweed, houndstongue (Cynoglossum officinale), tansy ragwort, and St. Johnswort are all toxic or repellent to livestock (Kingsbury, 1964; DiTomaso, 2000). Leafy spurge latex contains ingenols and macrocyclic diterpenes that are toxic and irritating to cattle, which avoid feeding near leafy spurge (Lym and Kirby, 1987; Hohmann et al., 1997). In Montana, cattle avoided grazing in areas with ten percent or greater leafy spurge cover (Hein and Miller, 1992). Russian knapweed and yellow starthistle contain repin, a sesquiterpene lactone that causes mouth ulcers and brain lesions in horses (Cordy, 1978; Robles et al., 1997). St. Johnswort contains hypericin, which causes symptoms ranging from severe dermatitis to hyperthermia when ingested by sheep or cattle (Bourke and White, 2004). Tansy ragwort and houndstongue contain pyrrolizidine alkaloids poisonous to cattle (Baker et al., 1991). In the 1970s along the Oregon coast, dairy herds suffered 2-10\% annual losses due to tansy ragwort poisoning (Coombs et al., 1999). Successful biological control of tansy ragwort has reduced associated animal poisonings (Turner and McEvoy, 1995; Coombs et al., 1999).

\subsubsection{Conversion of grasslands to other vegetation}

Woody invasive species reduce forage production by converting grasslands to shrublands. For example, prickly acacia (Acacia nilotica subsp. indica) was introduced into grasslands in western Queensland for livestock shade and as reserve forage in droughts. It now infests 6 million ha (Mackey, 1997), displacing native grass species and causing soil erosion (Johnson, 2004). In areas that are heavily infested, it is often uneconomical to reclaim the land, other than by biological control. Several agents have been introduced, including the moth Chiasmia assimilis, which is causing large scale defoliation in coastal areas (Palmer et al., 2007), and the bruchid beetle Bruchidius sahlbergi, which is widespread and attacks up to $65 \%$ of developing seeds (Radford et al., 2001). However, the problem is not yet resolved and further exploration for agents is occurring in India.

\subsection{Water from rivers}

In drier areas of the world, invasive plants can be a major threat to water supplies from rivers. Among the species contributing most to water loss are invasive riparian plants such as Australian Acacia andEucalyptus, northern hemisphere Pinus, Asian Tamarix (saltcedar) (Nagler et al., 2008; van Wilgen et al., 2008), and European Arundo donax (giant reed) (Seawright et al., 2009). Such plants reduce water flow by clogging channels and increase water loses from evapotranspiration. Although the amount of water being lost is debated (Shafroth et al., 2005), Zavaleta (2000) estimated that losses in the western USA from effects of saltcedar on irrigation water, municipal water, hydropower, and flood control were \$133-285 million/year. Similarly, Seawright et al. (2009) estimated that $\$ 4.75$ million worth of water could potentially be saved annually through biological control of giant reed in the lower Rio Grande Valley of Texas. In South Africa, plant invasion models showed that up to $58 \%$ of the nation's water could be lost if 
invasive plant populations went uncontrolled (van Wilgen et al., 2008), and a massive campaign ('Working for Water') was created to remove invasive trees from water courses. Other management programs to suppress invasive riparian plants exist in North America, Australia, and the Middle East, principally against giant reed and saltcedar (Bell, 1997; Kelly et al., 1998; Csurhes and Edwards, 1998; Williams and West, 2000).

Although cutting, burning, and herbicide applications are commonly used for immediate removal of invasive woody plants, biological control is a key element for effective programs, to slow spread and prevent re-infestation. This is often achieved by releasing agents that lower seed production and/or seedling survival. In some cases, mature plants may be directly affected by biological control agents, as for example defoliation of Tamarix spp. by Diorhabda chrysomelids in the USA (Carruthers et al., 2008).

South Africa's struggle to protect its water supplies from invasive woody plants is the clearest example of the threat from such invasive plants and the potential role of biological control. Particularly in the mountains of the Western Cape, invasive Pinus, Acacia, Hakea, and Sesbania have greatly increased the total plant biomass compared to that of the native vegetation, thus increasing water use. This has led to localized reductions of river outflow of 3080\% (van Wilgen et al., 1992; Le Maitre et al., 1996). These invasive trees were imported mainly for use as timber or ornamentals. In most cases, the public wants these uses to continue. Therefore, biological control agents could not be used to kill mature plants. The goal, rather, was to reduce spread outside of cities and forestry plantations by limiting seed production and/or lowering seedling survival. These effects, combined with mechanical removal of mature trees, allowed plant populations to be suppressed in desired areas, without threatening economic and aesthetic uses of these trees in other areas. To date, no success has been achieved against Eucalyptus or Pinus. Biological control, however, has been effective against species of Acacia and Sesbania (Moran et al., 2005), with best success against Acacia longifolia, Acacia saligna, Acacia pycnantha, and Sesbania punicea (Hoffmann and Moran, 1998; Dennill et al., 1999). Before its biological control, A. longifolia was a topranked South African weed. Two biological control agents, the flower-galling pteromalid wasp Trichilogaster acaciaelongifoliae and the seed weevil Melanterius ventralis, reduced seed production of $A$. longifolia by $>95 \%$ (Dennill et al., 1999). As existing stands were killed by fires, lack of seed prevented their replacement. Acacia longifolia is concentrated along water courses and in the absence of its biological control, this species would have continued to deplete water resources in many catchments.

Sesbania punicea is a leguminous tree from South America that forms dense bands $20-30 \mathrm{~m}$ wide along South African rivers. The impact of the tree on water flow was never quantified but it grows where water is plentiful, suggesting strong demand and high transpiration rates. Three beetle species were introduced for its biological control in the 1970s: Trichapion lativentre, a bud feeding apionid; Rhyssomatus marginatus, a seed-feeding weevil; and Neodiplogrammus quadrivittatus, a stem boring weevil (Hoffmann and Moran, 1991). Collectively they curtailed S. punicea reproduction and destroyed existing plants. Plant density declined by $>95 \%$ in most areas and current levels are not problematic (Hoffmann and Moran, 1998). In many regions, stretches of rivers once clogged with $S$. punicea are again open and free flowing (Hoffmann, personal observations).

\subsection{Electricity generation}

Production of hydroelectric power depends on reliable water flow. Blockage by invasive plants such as waterhyacinth, water lettuce, and giant salvinia, can create flow shortages (Holm et al., 1969; Rørslett, 2006; Liabunya, 2007). Invasive aquatic plants can also increase siltation and detritus build-up, reducing the life of reservoirs (Moorhead et al., 1988; Liabunya, 2007). The Jebel Aulia Dam on the White Nile in Sudan, for example, became clogged by waterhyacinth within 10 years of its invasion (Holm et al., 1969; Beshir and Bennett, 1985). A power station on the Waikato River in New Zealand had to be shut down due to a massive infestation by the invasive submersed plant Ceratophyllum demersum (Chapman et al., 1974). Operations of power stations on the Shire River in Malawi were disrupted in the 1990s by floating islands of waterhyacinth, giant salvinia, and water lettuce, which choked intake screens and caused silt build-up at intake ponds. The resulting interruptions in the electrical power supply affected the economy by reducing industrial production (Liabunya, 2007). Similar problems occurred at stations on the Kafue River in Zambia (Chola, 2001) and at Owen Falls in Uganda (Appelgren et al., 2000). Biological control of waterhyacinth, water lettuce, and giant salvinia the weeds most disruptive to electrical power generation in warm regions - has been achieved in many locations (Table 2) and details of the biological control of these species are presented in the previous section on biodiversity.

\subsection{Commercial, recreational, or subsistence fishing or hunting}

Wildlands are widely used for harvesting wild fish or game species for commerce, recreation, or subsistence consumption. Invasive species, especially plants, can lower the quality of fish or game habitat, reducing this form of human use of wildlands.

\subsubsection{Fishing}

Damaging effects of invasive plants on commercial or subsistence fishing are well documented. In Benin (Africa), waterhyacinth infestations interfered with the use of nets and destroyed fish breeding grounds, causing annual losses of $\$ 84$ million/year (De Groote et al., 2003). After suppression of this invasive plant with biological control, fishing resumed (Ajuonu et al., 2003), and fishermen incomes increased \$30.5 million/year (De Groote et al., 2003). In Kenya, the Lake Victoria fishery in the Winam Gulf, with a net worth of $\$ 83$ billion that supports 15 million people (Opande et al., 2004), was reduced when waterhyacinth blocked fish landing spots, destroyed fishing gear, and interfered with water transportation of the catch (Opande et al., 2004). Biological control of waterhyacinth on Lake Victoria restored economic viability to the fishing industry. In Papua New Guinea, infestations of salvinia prevented fishermen from setting fish nets and fouled nets set in open water (Mitchell, 1981). By 1978, salted fish production from infested areas dropped $30 \%$. Biological control of salvinia cleared plant mats (Thomas and Room, 1986a), permitting fishing to return to normal levels. In the Congo, fishing ceased in salvinia- or water lettuce-infested areas, but resumed after there plants were suppressed by biological control (Mbati and Neuenschwander, 2005).

\subsubsection{Hunting}

Invasive plants affect game hunting in wild areas by changing forage levels and habitat features. In Idaho, areas infested by yellow starthistle were used 33\% less than uninfested areas by chukars (Alectoris chukar), a popular game bird (Lindbloom et al., 2004). In the western USA, elk (Cervus elaphus) hunting is a popular sport carried out in natural habitats that are now widely invaded by plants such as Russian knapweed, St. Johnswort, leafy spurge, yellow starthistle, and knapweeds (Stalling, 1998). In western Montana, areas dominated by spotted knapweed are not used as major feeding areas by elk, which prefer grasses (Kufeld, 1973). Spotted knapweed-infested areas received only $2 \%$ as much elk use as areas with bluebunch wheatgrass ( $P$. spicata) (Hakim, 1979). Infestation of elk winter range in Montana by spotted knapweed caused an estimated loss of 220 elk (Spoon et al., 1983). At 
$\$ 1063$ value per animal (Fried et al., 1995), this is an annual loss of $\$ 234,000$. Similarly, infestation of rangeland with leafy spurge reduced use from bison (Bison bison) 83\% and from deer by $70 \%$ (Trammell and Butler, 1995). Leafy spurge reduced browsing by big game animals in green ash (Fraxinus pennsylvanica)-chokecherry (Prunus virginiana) habitat by $32 \%$ (Trammell and Butler, 1995). Tansy ragwort has very low palatability to black-tailed deer (Odocoileus hemionus) (Dean and Winward, 1974). Biological control projects against spotted knapweed, leafy spurge, and tansy ragwort have been successful in many areas (Table 2 ).

\subsection{Water transport}

Aquatic invasive plants infesting navigable waterways can impede boat traffic. Waterhyacinth blocked steamboat traffic on the St. John's River in Florida in the late 1800s (Buker, 1982). During this period, steamboats and other craft were unable to reach docks or pass through navigable channels beneath bridges because of waterhyacinth (Zeiger, 1962). Waterhyacinth also interfered with use of seaplanes in the 1940s (Zeiger, 1962). In developing countries where roads may be non-existent, and local people may depend on small boats for their livelihood, trade, or for access to critical services, such blockages of rivers or lakes can be life-threatening. Salvinia infestations have fouled the propellers of small boats (Abbasi and Nipaney, 1986) and damaged their engines (Mitchell, 1980). On the Sepik River in Papua New Guinea, blockages caused by salvinia and waterhyacinth cut off many people's access to villages, schools, market places, as well as to fishing, hunting and gardening grounds, and to locations of administrative and health services. Some people subsisted on dried coconuts because they could not reach fishing areas, or obtain sago palm, or trade for food. Some villages were abandoned (Thomas and Room, 1986b) but were re-occupied after successful biological control of salvinia (Room and Thomas, 1985). Similarly, villages were abandoned in the Congo when waterways were blocked by waterhyacinth (Mbati and Neuenschwander, 2005). In the 1980s, waterhyacinth prevented navigation on the River Niger (Farri and Boroffice, 1999) and in the 1990s, prevented movement of ferries in and out of the port at Mwanza, Tanzania (Mallya, 1999). From 1995 to 1997, police boats based in Kisumu, Kenya could not operate because waterhyacinth infestations blocked their access to the lake. In this same period, waterhyacinth prevented large vessels that transported goods and people between Kenya, Uganda, and Tanzania from docking at the Kisumu Railway Pier, resulting in substantial economic losses (Mailu et al., 1999). Weed clearance to maintain ship passage for docking at Port Bell, Uganda cost US \$3-5 million from 1994 to 1997 (Mailu, 2001).

\subsection{Recreational land use}

Invasive plants can impede outdoor recreation. In Nevada (USA), economic costs of invasive plants on wildlife-related recreation were estimated as \$6-12 million/year (Eiswerth et al., 2005). The US National Park Service funds a team in California whose sole function is to remove invasive plants in National Parks. Yellow starthistle, which is toxic to horses (Cordy, 1978), increases the cost of keeping horses for recreation because of the need to keep the weed out of pastures and forage fed to horses. In South Africa, $O$. stricta invaded a large portion of Kruger National Park, used for game viewing. To remove the aesthetic blemish of dense invasive cacti in an otherwise pristine area, substantial funds were spent on an herbicide program, which ultimately failed (Hoffmann et al., 1998). Subsequently, two introduced biological control agents, the pyralid moth $C$. cactorum and the cochineal insect Dactylopius opuntiae, reduced the opuntia biomass in the park by $>90 \%$ (Hoffmann and Moran, 2008).

\section{Protecting valuable ecosystem services}

In addition to being sources of raw materials for human societies, natural ecosystems perform ecosystem services supporting environmental conditions that are beneficial and sustainable for many species, including humans. Some services are to provide habitat for vertebrate wildlife, protect soils, maintain hydrological, biogeochemical, or fire cycles, and preserve air quality. Some invasive species diminish these services and such changes are often permanent because affected areas are too large or remote for use of pest control approaches other than biological control. Biological control projects against the species discussed below have either been successful or are in progress as discussed above (see also Table 2).

\subsection{Maintenance of soils}

Invasive species can affect soil attributes, including erosion rate, moisture, salinity, $\mathrm{pH}$, nitrogen availability, tilth, and leaf litter depth. Of these, impacts on erosion, moisture, salinity, and nitrogen levels have been reduced in some instances through biological control of invasive plants and are discussed here.

\subsubsection{Soil erosion}

Increased rates of soil erosion, often from agriculture or other human use of land, have long been of concern. In general, any change in vegetative cover has potential to change erosion rates. Some accidentally introduced plants accelerate erosion by reducing ground cover, as is the case when grasslands are invaded by shrubs, vines, or forbs. Examples include knapweeds (Lacey et al., 1989; Wilcox et al., 1996) in Montana, and prickly acacia (Mackey, 1997) and rubber vine in Australia (Vogler and Lindsay, 2002). In extreme cases, invasive plants may increase landslides, as does miconia, a shallow rooted tree that replaced native forests on steep slopes in Tahiti (Meyer and Florence, 1996). Conversely, some reductions in soil erosion rates may be biologically undesirable, such as the use of exotic plants to "stabilize" dune systems (e.g., Reckendorf et al., 1985; see also earlier discussions under "Coastal Areas and Sand Dunes"), which harms the unique native biota associated with these high disturbance environments. Restoration of normal erosion rates depends on a return of the habitat to a vegetation cover level similar to that before invasion. Biological control projects are currently making significant progress against knapweeds, rubber vine, and miconia (Table 2).

\subsubsection{Increased dryness and salinity}

In the southwestern USA, removal of water for irrigation and loss of pulse flooding over river banks (due to dams) have made riparian areas drier and more saline (Glenn and Nagler, 2005). These conditions have been worsened by saltcedar infestations, which are more tolerant of increased groundwater salinity than many local native trees. As local species such as Populus fremontii declined (Pataki et al., 2005; Cleverly et al., 1997), saltcedars expanded their ecological dominance in riparian areas in the region. Saltcedar's high water use further increased groundwater salinity (at sites not immediately adjacent to rivers) (Nagler et al., 2008) and depressed native plant recruitment (Sher et al., 2002). Dryness of soil surfaces under saltcedar increased fires, leading to even higher levels of aridity and salinity (Busch and Smith, 1993). Reversing these outcomes will require substantial reductions in saltcedar coverage. Biological control of saltcedar is emerging, with widespread defoliation occurring at sites where agents have been released (Table 2).

In another case, infestation of yellow starthistle have made soils in some California annual grasslands drier, both to a greater depth and longer in the year, than uninfested areas (Enloe et al., 2004). 
Reversal of this condition will also depend on the biological control of the invasive plant. Biological control of yellow starthistle is developing and has been successful in some areas (Table 2).

\subsubsection{Changes in fertility}

Habitats with low soil fertility, such as the fynbos of South Africa, have experienced increased fertility when invaded by nitrogen-fixing plants. Change in soil fertility may facilitate additional invasions and depress native plant growth. In the fynbos, invasion of several Acacia species has enhanced soil organic matter and nitrogen levels (Stock et al., 1995). In the Riverlands Nature Reserve in the Western Cape, A. saligna stands produced four times the litter fall of pristine fynbos, and acacia litter had twice as much nitrogen per gram as fynbos litter. Levels of nitrogen returned to the soil by the above-ground biomass were 10 -fold higher under acacia than fynbos plants (Yelenik et al., 2004). Nitrogen inputs stimulated the growth of invasive native grasses such as Erharta calycina (Yelenik et al., 2004) and promoted invasion by exotic grasses (Holmes and Cowling, 1997). Growth of some fynbos species is reduced under elevated nitrogen (Lamb and Klaussner, 1988). In response to threats posed by A. saligna to fynbos biodiversity and water outflows from infested catchments, $A$. saligna was controlled with an introduced fungus, Uromycladium tepperianum (Saccado), which lowered tree density 87-98\% (Wood and Morris, 2007). Five other invasive Acacia species have also been targets of biological control in South Africa, with considerable success (Moran et al., 2005), especially against $A$. longifolia and $A$. pycnantha.

\subsection{Maintenance of historical hydrological conditions}

Some invasive plants have the capacity to alter hydrological conditions, increasing flood crests or diminishing river outflows. Flooding, while damaging at times to human interests, is necessary to create and maintain natural flood-adapted communities along riparian corridors (e.g., Stromberg et al., 1997). As with fire, flood regimes become ecologically problematic if they depart from historical norms. In this regard, the major factor driving change is physical modification of rivers (channelization, bank stabilization, and damming). However, invasive species may also alter flood regimes. Dense stands of giant reed can increase flooding by several mechanisms, including increased stream sedimentation during non-flood periods in rivers and floodway channels, which can decrease channel depth by more than $1 \mathrm{~m}$ (Frandsen and Jackson, 1994). Secondly, flood heights can be increased by reduction in flood water velocity as floods push through dense reed stands. Lower velocity can increase sedimentation during floods, further narrowing and clogging channels (Graf, 1980). Thirdly, piles of loose reeds, lodged against bridges and other structures, can increase over-bank flooding (Frandsen and Jackson, 1994). Similar problems are caused by saltcedar in the southwestern USA, where riparian infestations reduce channel width and depth, increasing frequency and severity of flooding (Graf, 1978, 1980; Blackburn et al., 1982). Biological control against giant reed has been initiated (Tracey and DeLoach, 1998), with a gall wasp and an armored scale first released in the Rio Grande River valley in Texas in 2009 (Goolsby, personal communication).

Another effect of invasive plants in dry areas is to reduce discharge volumes of rivers by using more water than the displaced native vegetation. In South Africa's Western Cape, native Protea shrubs were displaced by invasive woody trees. These trees increased plant biomass in the mountain fynbos up to 10-fold (Versfeld and van Wilgen, 1986), decreasing river discharge volumes 30-80\% (van Wilgen et al., 1992; Le Maitre et al., 1996). This problem has been reduced through successful biological control of several of the most important invasive species (Moran et al., 2005), in combination with manual clearance.

\subsection{Conservation of normal fire regimes}

Many plant communities have characteristic fire regimes (seasonality, frequency and intensity) that structure community composition and interspecific interactions. Such fire-mediated relationships can be disrupted if invasive plants change the nature of the available fuels, including quantity, spatial distribution, and ignitability (Brooks et al., 2004). Altered fire regimes can in turn dramatically change community structure, composition, or function. Some invasive plants gain a competitive advantage over native plants by their extreme fire tolerance or quick regrowth after fire, creating a positive feedback between invasion and fire. Biological control can help restore fire regimes to historical norms favorable to native plants and insects. Grasses are the invasive plant group that has most changed fire regimes (Brooks and Pyke, 2001), but they have rarely been biological control targets because many invasive grasses are valued as forage, set abundant seed, and regrow quickly after defoliation. Also, many grass-feeding insects are generalists that could pose non-target risks. However, some specialized insects and plant pathogens of grasses are known and with study more will be discovered. Therefore, it is likely that in the future some of the projects against invasive grasses that have been suggested will be carried out. Currently only a few species of grass (e.g., A. donax and Panicum maximum in the USA and Nassella spp. in Australia) are targets of on-going biocontrol projects (Goolsby and Moran, 2009). Here we discuss four fire-altering invasive plants - Chromolaena odorata, melaleuca, Old World climbing fern, and gorse - that are targets of biological control projects (Table 2).

Chromolaena odorata is a Neotropical shrub that has become widely invasive in the Old World. In areas with a distinct dry season, $C$. odorata increases the fire hazard because its dry pithy stems and leaves contain oils and increase fuel loads (McFadyen, 2004). In South Africa, the plant grows along forest margins, replacing vegetation of low flammability, and allows fires to penetrate the forest. Two biotypes of $C$. odorata have invaded different countries. The biotype in Asia has been substantially controlled in Papua New Guinea (Day and Bofeng, 2007) and East Timor (Zachariades et al., 2009; Day, personal communication) by the gall fly Cecidochares connexa. Natural enemy releases in South African against another biotype have resulted in establishment, but control has not yet occurred (Zachariades et al., 2009).

Melaleuca has invaded swamp and marsh habitats in southern Florida. Dense stands increase fuel loads and fire intensity. In pine and cypress habitats, melaleuca litter and standing trees can change ground fires into canopy fires that kill native pines and cypress (Wade, 1981). Loss of these dominant native tree species, coupled with high survival of older melaleuca and intense post-fire melaleuca seeding (Hofstetter, 1991), produces melaleuca monocultures. Similarly, the slower decomposition of melaleuca litter (compared to grass) raises fuel loads in sawgrass marshes, increasing fire intensity (Flowers, 1991). Increased fire, coupled with structural and vegetative conversion, has greatly changed these native plant communities (Serbesoff-King, 2003). Biological control agents, together with cutting and use of herbicides, have controlled melaleuca in Florida, as discussed earlier in the biodiversity section (see also Table 2).

Old World climbing fern is invasive in many habitats in south Florida, where it forms thick skirts of dead fronds around tree trunks. These flammable skirts can carry ground fires into tree canopies. Trees that could withstand ground fires (normal to the region) are killed by such canopy fires. The wet soils of cypress sloughs naturally cause ground fires to die out at slough margins. But fern-coated trees draw fire into cypress stands when burning debris kites from tree to tree, bringing fire effects into new communities (Pemberton and Ferriter, 1998). Biological control of this fern is developing (Boughton and Pemberton, 2009) (Table 2). 
Gorse is a spiny European shrub that is a major invasive plant in Australia, western North America, Hawaii, New Zealand, and Chile, forming flammable thickets. Gorse quickly regrows after fire (Reyes et al., 2009), and seeds germinate from a long-lived seed bank. In Chile, gorse fires now occur in areas where fires were rarely started naturally by lightning and are most common between $36^{\circ} \mathrm{S}$ and $42^{\circ} \mathrm{S}$ latitude (Maldonado, 2006), a world biodiversity 'hotspot' (Arroyo et al., 2004).

\subsection{Air pollution reduction}

In dry-land cropping areas, invasive plants in fallow fields can increase the need for tillage, which produces wind-blown soil. Tumbleweeds (Salsola spp.) have this effect in the wheat areas of eastern Washington (USA) and surrounding states (Young, 2006). The fine soil particles $(<10 \mu \mathrm{m})$ produced are considered an air pollutant by the US-EPA (Sharratt and Lauer, 2006; Sharratt et al., 2007). Similar problems from Salsola occur in the San Joaquin Valley, California (http://www.arb.ca.gov/research/aaqs/pm/pm.htm). Biological control of Salsola is in progress (Smith, 2005; Smith et al., 2009; see also Table 2).

Air quality can also be lowered by allergenic pollens of invasive plants. Parthenium weed is a potent allergen (McFadyen, 1995). Although contact dermatitis is the greater problem, wind-borne parthenium pollen causes allergic rhinitis or nasobronchial allergy (Towers and Subba Rao, 1992; Agarwal and D'Souza, 2009). Biological control in Australia and India has succeeded in lowering flowering $40-82 \%$ at two study locations (Dhileepan, 2001; Dhileepan and Strathie, 2009).

\subsection{Provision of habitat for vertebrate wildlife}

Native plants provide essential food and habitat for native vertebrates, and invasive plants may displace essential species. While invasive plants sometimes are used by native wildlife, more often they lower wildlife habitat quality. Invasive insects may greatly reduce densities of particular plants. If these are foundation or keystone species, their loss may affect dependent wildlife.

\subsubsection{Loss of food}

Reduction in availability of wildlife food is a common effect of many invasive plants because they convert diverse plant communities into weed monocultures. The effects of spotted knapweed, leafy spurge, and tansy ragwort on ungulates in western North America were discussed previously. In Queensland, dense infestations of rubber vine along rivers are largely empty of native birds (Bengsen and Pearson, 2006), and rubber vine leaf litter is avoided by native lizards in preference to litter of native trees (Valentine et al., 2007). In North American wetlands, purple loosestrife has reduced food availability for amphibians (Brown et al., 2006). When cattails (Typha spp.) are replaced by loosestrife, tannin (which reduces digestibility) concentration in detritus increases, and algae found on submerged macrophyte stems shift from green algae (e.g., Spirogyra) toward less palatable blue green groups (e.g., Oscillatoria). In combination, these effects reduce performance of native amphibians such as the toad Bufo americanus (Brown et al., 2006).

\subsubsection{Lower habitat quality}

When invasive plants cause physical restructuring of communities or large vegetative changes, wildlife habitat quality is likely to decline. Invasion of subtropical riparian forests in Texas and southern California by giant reed caused a shift in structure from open forests to dense cane stands of little value to wildlife. In southern California, giant reed invasion affected birds most strongly, including the federally endangered bird Vireo bellii pusillus (Bell, 1997). Giant reed has the potential to dry up small desert rivers and its invasion of the Cuatro Ciénegas basin in northern Mexico threatens both the endemic darter Etheostoma segrex (Hendrickson and McGaugh, 2005) and rare freshwater microbial stromatolites (Garcia-Pichel et al., 2004).

In northern Australia, the invasion of $M$. pigra caused widespread loss of sedgelands, paperbark forests, lakes, and channels. In place of a floristic mosaic of structurally diverse habitats, M. pigra created a uniform shrubland of low biodiversity. Birds and lizards declined in response to this habitat change (Braithwaite et al., 1989). Loss of sedgelands affected the magpie goose (Anseranas semipalmata) and the brolga (Grus rubicunda). Loss of wet forests affected sacred ibis (Threskiornis aethiopicus), royal spoonbill (Platalea regia), and the rufous owl (Ninox rufa).

In South Africa, invasion by $C$. odorata around Lake St. Lucia (a World Heritage Site) lowered the temperature of soils used for nesting by Nile crocodiles (Crocodylus niloticus), unbalancing hatchling sex-ratio and threatening the species' persistence at the site (Leslie and Spotila, 2001).

In Chile, gorse invasions of native rainforests and grasslands have caused habitat loss for Darwin's fox, Pseudalopex fulvipes, one of the world's most endangered canids and for "Monito del monte" (Dromiciops gliroides), the only living representative of the marsupial order Microbiotheria, found in Nothofagus rainforest and Chusquea bamboo (CONAMA, 2009).

\subsubsection{Effects of invasive insects}

Insect invasions, unlike plant invasions that add a new dominant species, typically remove or degrade one or several native plants. The largest impacts of invasive insects are usually on their host plant and its monospecific herbivorous insects. Effects on vertebrates, however, may sometimes occur if the affected plants are keystone species with no functional substitute available. For example, loss of hemlock in the Appalachian Mts. (USA) due to hemlock woolly adelgid reduced native brook trout (Salvelinus fontinalis) density by as much $67 \%$ in parts of the Delaware Water Gap (Ross et al., 2003). In some instances, invasive insects may affect native vertebrates via mechanisms other than killing native plants. In New Zealand, invasive wasps (Vespula spp.) consumed honeydew deposits of native scales on southern beech (Nothofagus sp.), which formerly were an important food for bell birds, tuis and stichbirds (Beggs, 2001). Sphecophaga vesparum, a parasitoid of yellow jacket brood, was introduced but did not lower yellow jacket density (Beggs et al., 2008).

\section{Integration of biological control into comprehensive wildland invasive species management}

As illustrated by the case studies reviewed here, classical biological control is a powerful tool that can potentially resolve many invasive plant and insect problems in natural ecosystems. However, not all invasive species problems will be amenable to biological control, and the use of natural enemies should not be viewed as a panacea for unwanted exotic species. In some cases, effective agents may not be available, or agents may lack adequate specificity, especially if the targeted invasive species has many native congeneric relatives in the invaded area. In such cases, non-target risks may be too great to warrant the release of additional exotic species

Several other factors affect biological control's use in management plans. In some instances, several invasive species may all require control, such as groups of similar invasive plants. In such cases, biological control of one invader by itself may be insufficient to achieve a community's ecological restoration because a different resident weed may increase as the targeted species declines. In aquatic systems for example, waterhyacinth, water lettuce and giant salvinia may all be present in the same region. Biological control of just one member of the invasive floating-plant guild may 
lead to eruption of another invader that was formerly out-competed for control of space or resources by the dominant invader.

In other cases, a target plant may have uses society wishes to retain. Invasive wattles, acacias, and pines in South Africa are desired for their timber, beauty and shade, and biological control can only target their flowers and seeds in order to reduce their spread into natural ecosystems. In such cases, combining a biological control program against reproductive structures and seedlings with mechanical elimination of mature plants (by cutting and application of herbicides) may be necessary to suppress the invasive plant in wildlands.

More complex cases may arise if basic ecological processes have been damaged or terminated in ways that reduce the competitive abilities of native plants in the community. In dam-controlled desert river systems, loss of pulse flooding through controlled water releases may greatly reduce seedling establishment of native plants such as cottonwoods and willows that are needed as competitors in order to reduce invaders such as saltcedar. In such cases, biological control of saltcedar by itself may be inadequate for ecosystem restoration, and altered water management to allow floods and deliberate planting of native trees may be needed to recreate riparian able to sustain native biodiversity. Such programs may combine habitat management, biological control, and mechanical or chemical control.

\section{Conclusions}

Classical biological control is a powerful tool for suppression of invasive plants and insects in natural ecosystems. It will play an increasingly important part in ecological restoration because it provides a means to permanently suppress invaders over large landscapes without long-term resource commitments and hence is sustainable. As such, it merits use against many invasive plants and insects that are environmental pests in sensitive landscapes. Biological control efforts that are part of ecological restoration projects should set goals in concert with conservation biologists and ecologists and define the changes sought in the damaged native community. These goals should be unambiguous, peer-reviewed, and published in the public domain. As biological control projects unfold, monitoring of changes in pest density, together with responses of native species, particularly the non-target taxa identified as potentially at risk, should be carried out to quantify and document the program's effects (Morin et al., 2009). There should be a clear commitment to measure if and to what degree the target pest's density or range changes, and if native biodiversity is improved as a direct result of a given biological control project. Since population changes and community responses induced by biological control programs often require long periods (5-20 years) to reach stable end points, governments and other participating groups must be advised accordingly and projects must be planned and funded to cover such time periods. When carried out in this comprehensive manner, biological control of invasive plants and insects holds great promise for safeguarding biodiversity and wildlands, preserving and restoring ecosystem services and protecting valued natural resources.

\section{References}

Abbasi, S.A., Nipaney, P.C., 1986. Infestation of the fern genus Salvinia: its status and control. Environmental Conservation 13, 235-241.

Adair, R.J., 2005. The biology of Dasineura dielsi Rübsaamen (Diptera: Cecidomyiidae) in relation to the biological control of Acacia cyclops (Mimosaceae) in South Africa. Australian Journal of Entomology 44, 446-456.

Agarwal, K.K., D'Souza, M., 2009. Airborne contact dermatitis induced by parthenium: a study of 50 cases in South India. Clinical and Experimental Dermatology 34, E4-E6.

Ajuonu, O., Neuenschwander, P., 2003. Release, establishment, spread and impact of the weevil Neohydronomus affinis (Coleoptera: Curculionidae) on water lettuce (Pistia stratiotes) in Bénin, West Africa. African Entomology 11, 205-211.
Ajuonu, O., Schade, V., Veltman, B., Sedjro, K., Neuenschwander, P., 2003. Impact of the weevils Neochetina eichhorniae and N. bruchi (Coleoptera: Curculionidae) on waterhyacinth, Eichhornia crassipes (Pontederiaceae), in Benin, West Africa. African Entomology 11, 153-161.

Allen, E.B., 1982. Water and nutrient competition between Salsola kali and two native grass species (Agropyron smithii and Bouteloua gracilis). Ecology 63, 732-741.

Appelgren, B., Klohn, W., Alam, U., 2000. Water and Agriculture in the Nile Basin. Nile Basin Initiative Report to ICCON. Food and Agriculture Organization of the United Nations, Land and Water Division, Rome, Italy.

Anonymous, 1999. Mistflower Ageratina riparia. Auckland Regional Council Pest Facts Sheet No. 46. Available from: <http://www.arc.govt.nz/arc/library/ c28786_2.pdf/>.

Anonymous, 2000. Harvesters get that sinking feeling. Biocontrol News and Information $21,1 \mathrm{~N}-8 \mathrm{~N}$

Anonymous, 2004. Forest Insect and Disease Conditions in the United States 2003. United States Department of Agriculture, Forest Service, Forest Health Protection, p. 89.

Anonymous, 2009. Scrubwood regeneration website: <http://home.swipnet.se/ $\sim \mathrm{w}$-17282/endemic/scrubwood.html/> (accessed 23.06.09).

Arroyo, M.T.K., Marquet, P., Marticorena, C., Simonetii, J., Cavieres, L., Squeo, F.A. Rozzi, R., 2004. Chilean winter rainfall - Valdivian forests. In: Mittermeier, R.A., Robles Gil, P., Hoffmann, M., Pilgrim, J., Brooks, T., Goettsch, C., Lamoreux, J., Fonseca, G.A.B. (Eds.), Hotspots Revisited. CEMEX, México, pp. 99-103.

Ashmole, N.P., Ashmole, M.J., 1997. The land fauna of Ascension Island: new data from caves and lava flows, and a reconstruction of the prehistoric ecosystem. Journal of Biogeography 24, 549-589.

Austin, D.F., 1978. Exotic plants and their effects in southeastern Florida Environmental Conservation 5, 25-34

Ayres, D.R., Smith, D.L., Zaremba, K., Klohr, S., Strong, D.R., 2004. Spread of exotic cordgrasses and hybrids (Spartina sp.) in the tidal marshes of San Francisco Bay, California, USA. Biological Invasions 6, 221-231.

Badenes-Perez, F.R., Alfaro-Alpizar, M.A., Castillo-Castillo, A., Johnson, M.T., 2007 Biological control of Miconia calvescens with a suite of insect herbivores from Costa Rica and Brazil. In: Julien, M.H., Sforza, R., Bon, M.C., Evans, H.C., Hatcher P.E., Hinz, H.L., Rector, B.G. (Eds.), Proceedings of the XII International Symposium of Biological Control of Weeds, La Grande Motte, France, 22-27 April, 2007. CAB International, Wallingford, UK, pp. 129-132.

Bailey, J., Schweitzer, J., Whitham, T., 2001. Saltcedar negatively effects biodiversity of aquatic macroinvertebrates. Wetlands 21, 442-447.

Baker, D.C., Pfister, J.A., Molyneux, R.J., Kechele, P., 1991. Cynoglossum officinale toxicity in calves. Journal of Comparative Pathology 104, 403-410.

Baker, J.L., Webber, A.P., 2008. Feeding impacts of a leafy spurge (Euphorbia esula) biological control agent on a native plant, Euphorbia robusta. Invasive Plant Science and Management 1, 26-30.

Balciunas, J.K., Grodowitz, M.J., Cofrancesco, A.F., Shearer, J.F., 2002. Hydrilla. In: Van Driesche, R., Blossey, B., Hoddle, M., Lyon, S., Reardon, R. (Eds.), Biological Control of Invasive Plants in the Eastern United States. FHTET-2002-04, United States Department of Agriculture, Forest Service, Morgantown, West Virginia, USA, pp. 91-114.

Baldini, A., Oltremari, J., Holmgren, A., 2007. Effect of Cinara cupressi (Hemiptera: Aphididae) on Cordinellran cypress (Austrocedrus chilensis) after applying a chemical control. Ciencia e Investigación Agraria 35 (3), 289-298.

Bangsund, D.A., Leistritz, F.L., Leitch, J.A., 1999. Assessing economic impacts of biological control of weeds: the case of leafy spurge in the northern Great Plains of the United States. Journal of Environmental Management 56, 35-43.

Barton, J., Fowler, S.V., Gianotti, A.F., Winks, C.J., Beurs, M.D., Arnold, G.C., Forrester G., 2007. Successful biological control of mist flower (Ageratina riparia) in New Zealand: agent establishment, impact and benefits to the native flora. Biological Control 40, 370-385.

Bateman, H.L., Chung-MacCoubrey, A., Snell, H., 2008. Impact of non-native plant removal on lizards in riparian habitats in the southwestern United States. Restoration Ecology 16, 180-190.

Bauer, L.S., Liu, H., Gould, J.R., Reardon, R.C., 2007. Progress on biological control of the emerald ash borer in North America. Biocontrol News and Information 28 (3), $51 \mathrm{~N}-54 \mathrm{~N}$.

Baylis, J., Makungwa, S., Hecht, J., Nagoma, D., Bruessow, C., 2007. Saving the island in the sky: the plight of the Mount Mulanje cedar, Widdringtonia whytei in Malawi. Oryx 41 (1), 64-69.

Beardsley, J.W., 1955. Fluted scales and their biological control in United States administered Micronesia. Proceedings of the Hawaiian Entomological Society 15, 391-399.

Beggs, J., 2001. The ecological consequences of social wasps (Vespula spp.) invading an ecosystem that has an abundant carbohydrate resource. Biological Conservation 99, 17-28.

Beggs, J.R., Rees, J.S., Toft, R.J., Dennis, T.E., Barlow, N.D., 2008. Evaluating the impact of a biological control parasitoid on invasive Vespula wasps in a natural forest ecosystem. Biological Control 44, 399-407.

Bell, G.P., 1997. Ecology and management of Arundo donax, and approaches to riparian habitat restoration in southern California. Available from: <http:// teamarundo.org/ecology_impacts/arundo_ecology.pdf/>.

Ben-Dov, Y., Miller, D.R., Gibson, G.A.P., 2009. ScaleNet, Icerya purchasi, 12 August 2009. Available from: <http://www.sel.barc.usda.gov/catalogs/margarod/ Iceryapurchasi.htm/>.

Bengsen, A.J., Pearson, R.G., 2006. Examination of factors potentially affecting riparian bird assemblages in a tropical Queensland savanna. Ecologica Management and Restoration 7, 141-144. 
Beshir, M.O., Bennett, F.D., 1985. Biological control of waterhyacinth on the White Nile, Sudan. In: Delfosse, E.S. (Ed.), Proceedings of the VI International Symposium on Biological Control of Weeds. Agriculture Canada, Ottawa, Canada, pp. 491-496.

Blackburn, W.H., Knight, R.W., Schuster, J.L., 1982. Saltcedar influence on sedimentation in the Brazos River. Journal of Soil and Water Conservation 37, 298-301.

Blossey, B., Nuzzo, V., Hinz, H., Gerber, E., 2001a. Developing biological control of Alliaria petiolata (M. Bieb.) Cavara and Grande (garlic mustard). Natural Areas Journal 21, 357-367.

Blossey, B., Skinner, L.C., Taylor, J., 2001b. Impact and management of purple loosestrife (Lythrum salicaria) in North America. Biodiversity and Conservation 10, 1787-1807.

Boettner, G.H., Elkinton, J.S., Boettner, C.J., 2000. Effects of a biological control introduction on three nontarget native species of saturniid moths. Conservation Biology 14, 1798-1806.

Booth, R.G., Cross, A., Fowler, S.V., Shaw, R.H., 1995. The biology and taxonomy of Hyperaspis pantherina (Coleoptera: Coccinellidae) and the classical biological control of its prey, Orthezia insignis (Homoptera: Ortheziidae). Bulletin of Entomological Research 85, 307-314.

Boughton, A.J., Pemberton, R.W., 2009. Establishment of an imported natura enemy, Neomusotima conspurcatalis (Lepidoptera; Crambidae) against an invasive weed, Old World climbing fern, Lygodium microphyllum, in Florida. Biocontrol Science and Technology 19, 769-772.

Bourke, C.A., White, J.G., 2004. Reassessment of the toxicity of Hypericum perforatum (St. John's wort) for cattle. Australian Veterinary Journal 82, 707710.

Braithwaite, R.W., Lonsdale, W.M., Estbergs, J.A., 1989. Alien vegetation and native biota in tropical Australia: the impact of Mimosa pigra. Biological Conservation $48,189-210$

Brancatini, V.A., Sands, D.P.A., 1997. Control or no control of breadfruit mealybug (Icerya aegyptiaca): selecting the "right" species of Rodolia. In: Waterhouse, D.F. Ferrar, P. (Eds.), Second Workshop on Biological Control in the Pacific at Nadi, Fiji in 1995. South Pacific Commission, Noumea, New Caledonia, p. 56.

Brandt, C.A., Rickard, W.H., 1994. Alien taxa in the North American shrub-steppe four decades after cessation of livestock grazing and cultivation agriculture. Biological Conservation 68, 95-105.

Briese, D.T., 1997. Biological control of St. John's wort: past, present and future. Plant Protection Quarterly 12 (2), 73-80.

Briese, D.T., Pettit, W.J., Walker, A., 2004. Evaluation of the biological control agent, Lixus cardui, on Onopordum thistles: experimental studies on agent demography and impact. Biological Control: Theory and Application in Pest Management 31 (2), 165-171.

Brisbin, R.L., 1970. Eastern Hemlock. U.S. Department of Agriculture, Forest Service. American Woods - FS-239. Washington, DC, 8 pp.

Brooks, M.L., Pyke, D.A., 2001. Invasive plants and fire in the deserts of North America. In: Galley, K.E.M., Wilson, T.P. (Eds.), Proceedings of the Invasive Plant Workshop: The Role of Fire in the Control and Spread of Invasive Species. Tall Timbers Research Station, Tallahassee, FL, pp. 1-14.

Brooks, M.L., D’Antonio, C.M., Richardson, D.M., Grace, J.B., Keeley, J.E., DiTomaso, J.M., Hobbs, R.J., Pellant, M., Pyke, D., 2004. Effects of invasive alien plants on fire regimes. BioScience 54, 677-688.

Brown, C.J., Blossey, B., Maerz, J.C., Joule, S.J., 2006. Invasive plant and experimental venue affect tadpole performance. Biological Invasions 8, 327-338.

Buckingham, G.R., 2002. Alligatorweed. In: Van Driesche, R., Blossey, B., Hoddle, M., Lyon, S., Reardon, R. (Eds.), Biological Control of Invasive Plants in the Eastern United States. FHTET-2002-04, United States Department of Agriculture, Forest Service, Morgantown, West Virginia, USA, pp. 5-15.

Buisson, E., Holl, K.D., Anderson, S., Corcket, E., Hayes, G.F., Torre, F., Peters, A., Dutoit, T., 2006. Effects of seed source, topsoil removal, and plant neighbo removal on restoring California coastal prairies. Restoration Ecology 14, 569577.

Buker, G.E., 1982. Engineers vs. Florida's green menace. The Florida Historica Quarterly 60, 413-427.

Busch, D.E., Smith, S.D., 1993. Effects of fires on water and salinity relations of riparian woody taxa. Oecologia 94, 186-194.

Cagnotti, C., Mc Kay, F., Gandolfo, D., 2007. Biology and host specificity of Plectonycha correntina Lacordaire (Chrysomelidae), a candidate for the biological control of Anredera cordifolia (Tenore) Steenis (Basellaceae). African Entomology 15, 300-309.

Calderon Alvarez, C., 2002. Evaluación de la Eficací a de Rodolia cardinalis (Mulsant) (Coleoptera: Coccinellidae) en el Control Biológico de Icerya purchasi Maskell (Homptera: Margarodidae) en las Islas Galápagos. Tésis de grado. Pontifica Universidad Javeriana, Faculdad de Estudios Ambientales y Rurales, Bogota Colombia.

Callaway, J.C., Josselyn, M.N., 1992. The introduction and spread of smooth cordgrass (Spartina alterniflora) in South San Francisco Bay. Estuaries 15, 218 226.

Callaway, R.M., Cipollini, D., Barto, K., Thelen, G.C., Hallett, S.G., Prati, D., Stinson, K. Klironomos, J., 2008. Novel weapons: invasive plant suppresses fungal mutualists in America but not in its native Europe. Ecology 89, 1043-1055.

Caltagirone, L.E., Doutt, R.L., 1989. The history of the vedalia beetle importation to California and its impact on the development of biological control. Annual Review of Entomology 34, 1-16.

Campbell, F.T., Schlarbaum, S.E., 1994. Fading forests: North American trees and the threat of exotic pests. Natural Resource Defense Council Report, 47 pp.
Campbell, F.T., Schlarbaum, S.E., 2002. Fading Forests II. Trading Away North America's Natural Heritage. University of Tennessee, Knoxville, Tennessee, USA Campbell, R.W., Sloan, R.J., 1977. Forest stand responses to defoliation by the gypsy moth. Forest Science Monograph No. 19, 34 pp.

Carruthers, R.I., DeLoach, C.J., Herr, J., Anderson, G.L., Knutson, A.E., 2008. Saltcedar areawide pest management in the Western United States. In: Koul, O., Cuperus, G., Elliott, N. (Eds.), Areawide Pest Management: Theory and Practice. CABI, Cambridge, UK, pp. 271-299.

Casagrande, R.A., Dacey, J., 2007. Monarch butterfly oviposition on swallow-wort (Vincetoxicum spp.). Environmental Entomology 36, 631-636.

Causton, C.E., 2001. Dossier on Rodolia cardinalis Mulsant (Coccinellidae: Cocinellinae), a potential biological control agent for the cottony cushion scale, Icerya purchasi Maskell (Margarodidae). Charles Darwin Research Station, Galápagos Islands.

Causton, C.E., 2003. Ensuring compatibility of biological control of Icerya purchasi Maskell with conservation in Galapagos: development of procedure to evaluate risk. In: Van Driesche, R.G. (Ed.), Proceedings of the First International Symposium for the Biological Control of Arthropods. 14-18 January 2002, Honolulu, HI. FHTET-03-05, USDA-FS, Morgantown, WV, pp. 448-457.

Causton, C.E., Lincango, M.P., Poulsom, T.G.A., 2004. Feeding range studies of Rodolia cardinalis (Mulsant), candidate biological control agent of Icerya purchasi Maskell in the Galápagos Islands. Biological Control 29, 315-325.

Causton, C.E., Peck, S.B., Sinclair, B.J., Roque-Albelo, L., Hodgson, C.J., Landry, B., 2006. Alien insects: threats and implications for the conservation of the Galápagos Islands. Annals Entomological Society America 99, 121-143.

Cave, R.D., 2008. Biological control of the Mexican bromeliad weevil. Biocontrol News and Information 29, $1 \mathrm{~N}-2 \mathrm{~N}$

Center, T.D., Hill, M.P., Cordo, H., Julien, M.H., 2002. Waterhyacinth. In: Van Driesche, R., Blossey, B., Hoddle, M., Lyon, S., Reardon, R. (Eds.), Biological Control of Invasive Plants in the Eastern United States. FHTET-2002-04, United States Department of Agriculture, Forest Service, Morgantown, West Virginia, USA, pp. 41-64.

Center, T.D., Pratt, P.D., Tipping, P.W., Rayamajhi, M.B., Van, T.K., Wineriter, S.A. Dray Jr., F.A., 2007. Initial impacts and field validation of host range for Boreioglycaspis melaleucae Moore (Hemiptera: Psyllidae), a biological control agent of the invasive tree Melaleuca quinquenervia (Cav.) Blake (Myrtales: Myrtaceae: Leptospermoideae). Environmental Entomology 36, 569-576.

Chapman, V.J., Brown, J.M.A., Carr, J.L., 1974. Biology of excessive weed growth in the hydro-electric lakes of the Waikato River, New Zealand. Hydrobiologia 44, 349-363.

Cheah, C.A., McClure, M.S., 1998. Life history and development of Pseudoscymnus tsugae (Coleoptera: Coccinellidae), a new predator of the hemlock woolly adelgid (Homoptera: Adelgidae). Environmental Entomology 27, 1531-1536.

Chola, P., 2001. Management of aquatic weeds on the Kafue river in Zambia. In: Proceedings of the 27th WEDC Conference, Lusaka, Zambia, pp. 381-382.

Cleverly, J.R., Smith, S.D., Sala, A., Devitt, D.A., 1997. Invasive capacity of Tamarix ramosissima in a Mojave Desert floodplain: the role of drought. Oecologia 111, 12-18.

Cline, D., Juricek, C., Lym, R.G., Kirby, D.R., 2008. Leafy spurge (Euphorbia esula) control with Aphthona spp. affects seedbank composition and native grass reestablishment. Invasive Plant Science and Management 1, 120-132.

Coetzee, J.A., Hill, M.P., Julien, M.H., Center, T.D., Cordo, H.A., 2009. Eichhornia crassipes (Mart.) Solms-Laub. (Pontederiaceae). In: Muniappan, R., Reddy, G.V., Raman, A. (Eds.), Biological Control of Tropical Weeds using Arthropods. Cambridge University Press, New York, NY, pp. 183-210.

CONAMA, 2009. Corporación Nacional del Medio Ambiente website. Available from: <http://www.conama.cl/> (accessed June 2009).

Connor, J.M., 2003. Impacts of invasive species on rangelands. Proceedings California Weed Science Society 55, 26-31.

Cook, G.D., Setterfield, S.A., Maddison, J.P., 1996. Shrub invasion of a tropical wetland: implications for weed management. Ecological Applications 6, 531537.

Coombs, E.M., Radtke, H., Isaacson, D.L., Synder, S.P., 1996. Economic and regional benefits from the biological control of tansy ragwort, Senecio jacobaea, in Oregon. In: Moran, V.C., Hoffman, J.H. (Eds.), Proceedings of the IX International Symposium on Biological Control of Weeds, 19-26 January 1996, Stellenbosch, South Africa. University of Cape Town, Cape Town, South Africa, pp. 489-494.

Coombs, E.M., McEvoy, P.B., Turner, C.E., 1999. Tansy ragwort. In: Sheley, R.L. Petroff, J.K. (Eds.), Biology and Management of Noxious Rangeland Weeds. Oregon State University Press, Corvallis, pp. 389-400.

Coombs, E.M., Clark, J.K., Piper, G.L., Cofrancesco Jr., A., 2004. Biological Control of Invasive Plants in the United States. Oregon State University Press, Corvallis. 467 pp.

Cooper, W.P., Rieske, L.K., 2007. Community associates of an exotic gallmaker, Dryocosmus kuriphilus (Hymenoptera: Cynipidae), in eastern North America. Annals of the Entomological Society of America 100, 236-244.

Coppel, H.C., Mertins, J.W., Harris, J.W.E., 1974. The introduced pine sawfly, Diprion similis (Hartig) (Hymenoptera: Diprionidae). A review with emphasis on studies in Wisconsin. University of Wisconsin, Research Division, Research Bulletin R2393, $74 \mathrm{pp}$.

Cordy, D.R., 1978. Centaurea species and equine nigropallidal encephalomalacia. In: Keeler, R.F., Van Kampen, K.R., James, L.F. (Eds.), Effects of Poisonous Plants on Livestock. Academic Press, New York, pp. 327-336.

Cornett, M.W., Bauman, P.J., Breyfogle, D.D., 2006. Can we control leafy spurge? Adaptive management and the recovery of native vegetation. Ecological Restoration 24, 145-150. 
Coulson, J.R. 1977. Biological control of alligatorweed, 1959-1972. A review and evolution. ARS-USDA Technical Bulletin No. 1547, 98 pp.

Courant, A.V., Holbrook, A.E., Van Der Reijden, E.D., Chew, F.S., 1994. Native pierine butterfly (Pieridae) adapting to naturalized crucifer? Journal of the Lepidopterists' Society 48, 168-170.

Cox, G.W., 1999. Alien Species in North America and Hawaii. Impacts on Natural Ecosystems. Island Press, Washington, DC.

Cronk, Q.C.B., 1980. Extinction and survival in the endemic vascular flora of Ascension Island. Biological Conservation 17, 207-219.

Cronk, Q.C.B., 1989. The past and present vegetation of St. Helena. Journal of Biogeography 16, 47-64.

Csurhes, S., Edwards, R., 1998. Potential environmental weeds in Australia. National Weeds Program, Biodiversity Group, Environment Australia, Canberra, 205 pp.

Cuda, J.P., Ferriter, A.P., Manrique, V., Medal, J.C. (Eds.), 2006. Interagency Brazilian peppertree (Schinus terebinthifolius) Management Plan for Florida, second ed. Recommendations from the Brazilian Peppertree Task Force, Florida Exotic Pest Plant Council. South Florida Water Management District, West Palm Beach, FL. Available from: <http://www.fleppc.org/Manage_Plans/2006BPmanagePlan5. $\operatorname{pdf} />$.

Cuda, J.P., Medal, J.C., Gillmore, J.L., Habeck, D.H., Pedrosa-Macedo, J.H., 2009. Fundamental host range of Pseudophilothrips ichini sensu lato (Thysanoptera: Phlaeothripidae), a candidate biological control agent of Schinus terebinthifolius (Sapindales: Anacardiaceae) in the USA. Environmental Entomology 38, 16421652.

Cuming, F.G., 1961. The distribution, life history, and economic importance of the winter moth, Operophtera brumata (L.) (Lepidoptera: Geometridae) in Nova Scotia. Canadian Entomologist 93, 135-142.

Daehler, C.C., Strong, D.R., 1996. Status, prediction and prevention of introduced cordgrass Spartina spp. invasions in Pacific estuaries, USA. Biological Conservation 78, 51-58.

Davenport, D.C., Martin, P.E., Hagan, R.M., 1982. Evapotranspiration from riparian vegetation: conserving water by reducing saltcedar transpiration. Journal of Soil and Water Conservation 37 (4), 237-239.

Davies, J.T., Ireson, J.E., Allen, G.R., 2007. The impact of the gorse spider mite, Tetranychus lintearius, on the growth and development of gorse, Ulex europaeus. Biological Control 41, 86-93.

Davis, A.S., Landis, D.A., Nuzzo, V., Blossey, B., Gerber, E., Hinz, H.L., 2006. Demographic models inform selection of biocontrol agents for garlic mustard (Alliaria petiolata). Ecological Applications 16, 2399-2410.

Day, M.D., Wiley, C.J., Playford, J., Zalucki, M.P., 2003. Lantana: Current Management Status and Future Prospects. ACIAR, Canberra. 128 pp.

Day, M.D., Bofeng, I., 2007. Biocontrol of Chromolaena odorata in Papua New Guinea. In: Lai, P.-Y., Reddy, G.V.P., Muniappan, R. (Eds.), Proceedings of the 7th International Workshop on the Biological Control and Management of Chromolaena odorata and Mikania micrantha. National Pingtung University of Science and Technology, Taiwan, pp. 53-67.

Day, M.D., Zalucki, M.P., 2009. Lantana camara Linn. (Verbenaceae). In: Muniappan, R., Reddy, G.V.P., Raman, A. (Eds.), Biological Control of Tropical Weeds Using Arthropods. Cambridge University Press, Cambridge, UK, pp. 211-246.

Day, R., Kairo, M.T.K., Abraham, Y.J., Kfir, R., Murphy, S.T., Mutitu, K.E., Chilima, C.Z., 2003. Homopteran pests of conifers. In: Neuenschwander, P., Borgemeister, C. (Eds.), Biological Control in IPM Systems in Africa. CAB International, Wallingford, pp. 101-112.

Dean, R.E., Winward, A.H., 1974. An investigation into the possibility of tansy ragwort poisoning of black-tailed deer. Journal of Wildlife Diseases 10, 166169.

DEC, 2006. NSW Threat Abatement Plan: Invasion of Native Plant Communities by Chrysanthemoides monilifera (Bitou Bush and Boneseed). Department of Environment and Conservation, NSW, Hurstville, Australia.

De Groote, H., Ajuonu, O., Attignon, S., Djessou, R., Neuenschwander, P., 2003. Economic impact of biological control of waterhyacinth in southern Benin. Ecological Economics 45, 105-107.

DeLoach, C.J., Tracy, J.L., 1997. Effects of biocontrol of saltcedar (Tamarix ramosissima) on endangered species: draft biological assessment, 17 October 1997. Produced by USDA/ARS, Temple, Texas for the U.S. Fish and Wildlife Service, Region 2, Albuquerque, New Mexico, USA

DeLoach, C.J., Carruthers, R.I., Lovich, J.E., Dudley, T.L., 2000. Ecological interactions in the biological control of saltcedar (Tamarix spp.) in the United States. In: Spencer, N. (Ed.), Proceedings of the International Symposium on Biological Control of Weeds. Bozeman, Montana, USA, pp. 819-873.

Deloach, C.J., Moran, P.J., Knutson, A.E., Thompson, D.C., Carruthers, R.I., Michels, J., Herr, J.C., Muegge, M., Eberts, D., Randal, C., Everitt, J., O’Meara, S., Sanabria, J., 2008. Beginning success of biological control of saltcedars (Tamarix spp.) in the southwestern USA. In: Julien, M.H., Sforza, R., Bon, M.C., Evans, H.C., Hatcher, P.E., Hinz, H.L., Rector, B.G. (Eds.), XII International Symposium on Biological Control of Weeds. La Grande Motte, France, 22-27, April 2007. CABI, Wallingford, UK, pp. 535-539.

Dennill, G.B., Donnelly, D., Stewart, K., Impson, F.A.C., 1999. Insect agents used for the biological control of Australian Acacia species and Paraserianthes lophanth (Willd.) Nielsen (Fabaceae) in South Africa. African Entomology, Memoir No. 1, pp. $45-54$

Denoth, M., Myers, J.H., 2005. Variable success of biological control of Lythrum salicaria in British Columbia. Biological Control 32, 269-279.

Dhileepan, K., 2001. Effectiveness of introduced biocontrol insects on the weed Parthenium hysterophorus (Asteraceae) in Australia. Bulletin of Entomological Research 91, 167-176.
Dhileepan, K., 2003. Seasonal variation in the effectiveness of the leaf-feeding beetle Zygogramma bicolorata (Coleoptera: Chrysomelidae) and stem-galling moth Epiblema strenuana (Lepidoptera: Tortricidae) as biocontrol agents on the weed Parthenium hysterophorus (Asteraceae). Bulletin of Entomological Research 93, 393-401.

Dhileepan, K., Strathie, L., 2009. Parthenium hysterophorus L. (Asteraceae). In: Muniappan, R., Reddy, D.V.R., Raman, A. (Eds.), Biological Control of Tropica Weeds Using Arthropods. Cambridge University Press, UK, pp. 272-316.

Dhileepan, K., Snow, E.L., Rafter, M.A., Treviño, M., McCarthy, J., Senaratne, K.A.D.W 2007a. The leaf-tying moth Hypocosmia pyrochroma (Lep., Pyralidae), a hostspecific biological control agent for cat's claw creeper Macfadyena unguis-cati (Bignoniaceae) in Australia. Journal of Applied Entomology 131, 564-568.

Dhileepan, K., Treviño, M., Snow, E.L., 2007b. Specificity of Carvalhotingis visenda (Hemiptera: Tingidae) as a biological control agent for cat's claw creeper Macfadyena unguis-cati (Bignoniaceae) in Australia. Biological Control 41, 283290.

Diaz, R., Overholt, W.A., Samayoa, A., Sosa, F., Cordeau, D., Medal, J., 2008 Temperature-dependent development, cold tolerance, and potentia distribution of Gratiana boliviana (Coleoptera: Chrysomelidae), a biologica control agent of tropical soda apple, Solanum viarum (Solanaceae). Biocontrol Science and Technology 18, 193-207.

Ding, J., Reardon, R., Wu, Y., Zheng, H., Fu, W., 2006. Biological control of invasive plants through collaboration between China and the United States of America: a perspective. Biological Invasions 8, 1439-1450.

Diop, O., Hill, M.P., 2009. Quantitative post-release evaluation of biological control of floating fern, Salvinia molesta D.S. Mitchell (Salviniaceae), with Cyrtobagous salviniae Calder and Sands (Coleoptera: Curculionidae) on the Senegal River and Senegal River Delta. African Entomology 17, 64-71.

DiTomaso, J.M., 2000. Invasive weeds in rangelands: species, impacts and management. Weed Science 48, 255-265.

DiTomaso, A., Lawlor, F.M., Darbyshire, S.J., 2005. The biology of invasive alien plants in Canada. 2. Cynanchum rossicum (Kleopow) Borhidi [=Vincetoxicum rossicum (Kleopow) Barbar.] and Cynanchum louiseae (L.) Kartesz \& Gandh [=Vincetoxicum nigrum (L.) Moench]. Canadian Journal of Plant Science 85, 243 263.

Doane, C.C., McManus, M.L. (Eds.), 1981. The Gypsy Moth: Research Toward Integrated Pest Management. Technical Bulletin No. 1584. US Department of Agriculture, Forest Service, Washington, DC.

Dodd, A.P., 1940. The Biological Campaign Against Prickly Pear. Commonwealth Prickly Pear Board Bulletin, Brisbane. 177 pp.

Downey, P.O., 2006. The weed impact to native species (WINS) assessment tool results from a trial for bridal creeper (Asparagus asparagoides (L.) Druce) and ground asparagus (Asparagus aethiopicus L.) in southern New South Wales. Plant Protection Quarterly 21, 109-116.

Downey, P.O., Turnbull, I., 2007. The biology of Australian weeds 48. Macfadyena unguis-cati (L.) A.H. Gentry. Plant Protection Quarterly 22, 82-91.

Downey, P.O., Holtkamp, R.H., Ireson, J.E., Kwong, R.M., Swirepik, A.E., 2007. A review of the Chrysanthemoides monilifera biological control program in Australia: 1987-2005. Plant Protection Quarterly 22, 24-32.

Dray, F.A., Center, T.D., 1992. Biological Control of Pistia stratiotes L. (Waterlettuce) using Neohydronomus affinis Hustache (Coleoptera: Curculionidae). Miscellaneous Paper A-92-1. U.S. Army Engineers, Waterways Experiment Station, Vicksburg, MS.

Drooz, A.T. (Ed.), 1985. Insects of Eastern Forests, Miscellaneous Publication No. 1426, USDA Forest Service, Washington, DC.

Drooz, A.T., Doggett, C.A., Coppel, H.C., 1979. The introduced pine sawfly, a defoliator of white pine new to North Carolina. USDA Forest Service Research Note SE-273, Southeast Forest Experiment Station, Ashville, North Carolina, 3 pp.

Dudley, T.L., Kazmer, D.J., 2005. Field assessment of the risk posed by Diorhabda elongata, a biocontrol agent for control of saltcedar (Tamarix spp.), to a nontarget plant, Frankenia salina. Biological Control 35, 265-275.

Duncan, C.L., 2001. Knapweed management: another decade of change. In: Smith, L. (Ed.), Proceedings of the First International Knapweed Symposium of the Twenty-First Century, March 15-16, 2001, Coeur d'Alene, Idaho. USDA-ARS, Albany, CA, pp. 1-7.

EAB, 2009. Emerald Ash Borer. Available from: <http://www.emeraldashborer.info/ index.cfm/> (accessed March 2009).

Edwards, P.B., Adair, R.J., Holtkamp, R.H., Wanjura, W.J., Bruzzese, A.S., Forrester, R.I., 2009. Impact of the biological control agent Mesoclanis polana (Tephritidae) on bitou bush (Chrysanthemoides monilifera subsp. rotundata) in eastern Australia. Bulletin of Entomological Research 99, 51-63.

Eiswerth, M.E., Darden, T.D., Johnson, W.S., Agapoff, J., Harris, T.R., 2005. Inputoutput modeling, outdoor recreation, and the economic impacts of weeds. Weed Science 53, 130-137.

Elton, C.S., 1958. The Ecology of Invasions by Animals and Plants. The University of Chicago Press, Chicago, USA.

Embree, D.G., 1965. The population dynamics of the winter moth in Nova Scotia, 1954-1961. Memoirs of the Entomological Society of Canada No. 46, 57 pp.

Embree, D.G., 1967. Effects of the winter moth on growth and mortality of red oak in Nova Scotia. Forest Science 13, 295-299.

Embree, D.G., 1971. Operophtera brumata (L.), winter moth (Lepidoptera: Geometridae). In: Anonymous (Ed.), Biological Control Programmes Against Insects and Weeds in Canada, 1959-1968. Commonwealth Agricultura Bureaux, Farnham Royal, UK, pp. 167-175. 
Embree, D.G., Otvos, I.S., 1984. Operophtera brumata (L.) winter moth (Lepidoptera: Geometridae). In: Kelleher, J.S., Hulme, M.A. (Eds.), Biological Control Programmes in Against Insects and Weeds in Canada, 1969-1980. Commonwealth Agricultural Bureaux, Slough, UK, pp. 353-357.

Enloe, S.F., DiTomaso, J.M., Orloff, S.B., Drake, D.J., 2004. Soil water dynamics differ among rangeland plant communities dominated by yellow starthistle (Centaurea solstitialis), annual grasses, or perennial grasses. Weed Science 52 929-935.

Ens, E.J., French, K., 2008. Exotic woody invader limits the recruitment of three indigenous plant species. Biological Conservation 141, 590-595.

Ens, E.J., Bremner, J.B., French, K., Korth, J., 2009. Identification of volatile compounds released by roots of an invasive plant, bitou bush (Chrysanthemoides monilifera spp. rotundata), and their inhibition of native seedling growth. Biological Invasions 11, 275-287.

Eschtruth, A.K., Cleavitt, N.L., Battles, J.J., Evans, R.A., Fahey, T.J., 2006. Vegetation dynamics in declining eastern hemlock stands: 9 years of forest response to hemlock woolly adelgid infestation. Canadian Journal of Forest Research 36, 1435-1450.

Esler, K.J., Van Wilgen, B.W., Roller, K.S., Wood, A.R., van der Merwe, J.H., 2010. A landscape-scale assessment of the long-term integrated control of an invasive shrub in South Africa. Biological Invasions 12, 211-218.

Evans, H.C., Tomley, A.J., 1994. Studies on the rust, Maravalia cryptostegiae, potential biological control agent of rubber-vine weed, Cryptostegia grandiflora (Asclepiadaceae: Periplocoideae), in Australia, III: host range. Mycopathologia 126, 93-108.

Evans, R.A., 2002. An ecosystem unraveling? In: Onken, B., Reardon, R., Lashomb, J. (Eds.), Proceedings: Hemlock Woolly Adelgid in the Eastern United States Symposium, February 5-7, 2002. East Brunswick, New Jersey, The State University of New Jersey, Rutgers, New Jersey, pp. 23-33.

Farri, T.A., Boroffice, R.A., 1999. An overview on the status and control of waterhyacinth in Nigeria. In: Hill, M.P., Julien, M.H., Center, T.D. (Eds.), Proceedings of the First Global Working Group Meeting for the Biological and Integrated Control of Waterhyacinth. Harare, Zimbabwe, 1998, pp. 18-24.

Felt, E.P., Bromely, S.W., 1932. Observations on shade tree insects. Journal of Economic Entomology 28, 390-393.

Fielding, N.J., Evans, H.F., 1997. Biological control of Dendroctonus micans (Scolytidae) in Great Britain. Biocontrol News and Information 18 (2), 51N-60N.

Floyd, A.G., 1989. The vine weeds of coastal rainforest. In: Gorham, P. (Ed.), Noxious plant control: responsibility, safety and benefits, Proceedings of the 5th Biennial Noxious Plants Conference, vol. 1. New South Wales Agriculture and Fisheries, Sydney, pp. 109-115.

Flowers, J.D. II., 1991. Subtropical fire suppression in Melaleuca quinquenervia. In Center, T.D., Doren, R.F., Hofstetter, R.L., Myers, R.L., Whiteaker, L.D. (Eds.) Proceedings of the Symposium on Exotic Pest Pants. National Park Service, Denver, CO, NPS/NREVER/NRTR-91/06, pp. 151-158.

Fowler, S.V., 2004. Biological control of an exotic scale, Orthezia insignis Browne (Homoptera: Ortheziidae), saves the endemic gumwood tree, Commidendrum robustum (Roxb.) DC. (Asteraceae) on the island of St. Helena. Biological Control 29, 367-374

Frandsen, P., Jackson, N., 1994. The impact of Arundo donax on flood control and endangered species. In: Jackson, N.E., Frandsen, P., Duthoit, S. (Eds.), Arundo donax Workshop Proceedings, 19 November, 1993, Ontario, California. Team Arundo and California Exotic Pest Plant Council, Pismo Beach, California, pp. 13 16.

Frank, J.H., Cave, R.D., 2005. Metamasius callizona is destroying Florida's native bromeliads. In: Hoddle, M.S. (Ed.), Second International Symposium on Biological Control of Arthropods, Davos, Switzerland, September 12-16, 2005, vol. 1. FHTET-2005-08, USDA Forest Service Publication, pp. 91-101.

Frank, J.H., Fish, D., 2008. Potential biodiversity loss in Florida bromeliad phytotelmata due to Metamasius callizona (Coleoptera: Dryophthoridae), an invasive species. Florida Entomologist 91, 1-8.

Frank, J.H., Thomas, M.C., 1994. Metamasius callizona (Chevrolat) (Coleoptera: Curculionidae), an immigrant pest, destroys bromeliads in Florida. Canadian Entomologist 126, 673-682.

Fried, B.M., Adams, R.M., Berrens, R.P., Bergland, O., 1995. Willingness to pay for a change in elk hunting quality. Wildlife Society Bulletin 23, 680-686.

Friedmann, F., 1994. Flore des Seychelles - Dicotyledones. Editions de l'Orstom, Paris. 663 pp.

Gann, G.D., Bradley, K., Woodmansee, S.W., 2001. Floristic Inventory of South Florida Database. Available from: <www.regionalconservation.org/>

Garcia-Pichel, F.A., Al-Horani, J.D., Farmer, R., Ludwing, B.D.Wade., 2004. Balance between microbial calcification and metazoan bioerosion in modern stromatolitic oncolites. Geobiology 2, 1-49.

Garcia-Rossi, D., Rank, N., Strong, D.R., 2003. Potential for self-defeating biological control? Variation in herbivore vulnerability among invasive Spartina genotypes. Ecological Applications 13, 1640-1649.

Gates, M., Delvare, G., 2008. A new species of Eurytoma (Hymenoptera: Eurytomidae) attacking Quadrastichus spp. (Hymenoptera: Eulophidae) galling Erythrina spp. (Fabaceae), with a summary of African Eurytoma biology and species checklist. Zootaxa 1751, 1-24.

Gerber, E., Krebs, C., Murrell, C., Moretti, M., Rocklin, R., Schaffner, U., 2008. Exotic invasive knotweeds (Fallopia spp.) negatively affect native plant an invertebrate assemblages in European riparian habitats. Biological Conservation 141, 646-654.

Gery, R., 1991. Etude expérimentale de la prédation de la cochenille des Seychelles Icerya seychellarum (Westwood) par deux coccinelidae Rodolia cardinalis
(Mulsant) et Rodolia chermesina (Mulsant). Application a lutte biologique sur L'Atoll Aldabra. Thèse de Doctorate de L'Université de Rennes, France.

Ghent, J.H., Huber, C.M., Williams, R.S., 1982. Status report of the introduced pine sawfly in the southern Appalachians. USDA, Forest Service, State and Private Forestry, Southeast Area, Forest Pest Management Report 83-1-1. Atlanta, Georgia, 18 pp.

Gillespie, D.R., Finlayson, T., Tonks, N.V., Ross, D.A., 1978. Occurrence of the winter moth, Operophtera brumata (Lepidoptera: Geometridae), on southern Vancouver Island, British Columbia. The Canadian Entomologist 110, 223-224.

Gillock, H.H., Hain, F.P., 2001. A historical overview of North American gypsy moth controls, chemical and biological, with emphasis on the pathogenic fungus, Entomophaga maimaiga. Reviews in Toxicology 4, 105-128.

Glenn, E.P., Nagler, P.L., 2005. Comparative ecophysiology of Tamarix ramosissima and native trees in western U.S. riparian zones. Journal of Arid Environments 61, 419-446.

Goeden, R.D., 1978. Biological control of weeds. In: Clausen, C.L. (Ed.), Introduced Parasites and Predators of Arthropods Pests and Weeds: A World Review. USDA Agriculture Handbook No. 480, Washington, DC, pp. 357-314.

Gomez, P., Belov, M., San Martín, J., 2008. New Geographical locality for Berberis negeriana Tischle (Berberidaceae) in the province of Arauco, Bio- Bio region, Chile. Gayana Botánica 65, 109-110.

Goolsby, J.A., Moran, P.J., 2009. Host range of Tetramesa romana Walker (Hymenoptera: Eurytomidae), a potential biological control of giant reed, Arundo donax L. in North America. Biological Control 49, 160-168.

Gordon, A.J., 1999. A review of established and new insect agents for the biological control of Hakea sericea Schrader (Proteaceae) in South Africa. African Entomology Memoir No. 1, pp. 35-43.

Gordon, D.R., Gann, G.D., Carter, E., Thomas, K., 1999. Post-hurricane vegetation response in South Florida Hammocks with and without Dioscorea bulbifera L. control. In: Jones, D.T., Gamble, B.W. (Eds.), Florida's Garden of Good and Evil. South Florida Water Management District, West Palm Beach, pp. 309-326.

Graf, W.L., 1978. Fluvial adjustments to the spread of tamarisk in the Colorado Plateau region. Geological Society of America Bulletin 89, 1491-1501.

Graf, W.L., 1980. Riparian management: a flood control perspective. Journal of Soil and Water Conservation 35, 158-161.

Gramling, C., 2005. Hawaii's coral trees feel the sting of foreign wasps. Science 310 , 1759-1760.

Grandgirard, J., Hoddle, M.S., Roderick, G.K., Petit, J., Percy, D., Putoa, R., Garnier, C., Davies, N., 2006. Invasion of French Polynesia by the glassy-winged sharpshooter, Homalodisca coagulata (Hemiptera: Cicadellidae): a threat to the South Pacific. Pacific Science 60, 429-438.

Grandgirard, J., Hoddle, M.S., Petit, J.N., Percy, D.N., Roderick, G.K., Davies, N., 2007. Pre-introductory risk assessment studies of Gonatocerus ashmeadi (Hymenoptera: Mymaridae) for use as a classical biological control agent against Homalodisca vitripennis (Hemiptera: Cicadellidae) in the Society Islands of French Polynesia. Biocontrol Science and Technology 17, 809-822.

Grandgirard, J., Hoddle, M.S., Petit, J.A., Roderick, G.K., Davies, N., 2008. Engineering an invasion: classical biological control of the glassy-winged sharpshooter, Homalodisca vitripennis, by the egg parasitoid Gonatocerus ashmeadi in Tahiti and Moorea, French Polynesia. Biological Invasions 10, 135-148.

Gratwicke, B., Marshall, B.E., 2001. The impact of Azolla filiculoides Lam. on animal biodiversity in streams in Zimbabwe. African Journal of Ecology 38, 1-4.

Grégoire, J.C., 1988. The greater European spruce beetle. In: Berryman, A.A. (Ed.), Dynamics of Forest Insect Populations. Plenum Publishing Corporation, New York, USA, pp. 455-478.

Grevstad, F.S., 2006. Ten-year impacts of the biological control agents Galerucella pusilla and G. calmariensis (Coleoptera: Chrysomelidae) on purple loosestrife (Lythrum salicaria) in central New York. Biological Control 39, 1-8.

Grevstad, F.S., Strong, D.R., Garcia-Rossi, D., Switzer, R.W., Wecker, M.S., 2003. Biological control of Spartina alterniflora in Willapa Bay, Washington using the planthopper Prokelisia marginata: agent specificity and early results. Biological Control 27, 32-42.

Grodowitz, M.J., Cofrancesco, A.F., Stewart, R.M., Madsen, J., Morgan, D., 2003. Possible impact of Lake Seminole Hydrilla by the introduced leaf-mining fly Hydrellia pakistanae. ERDC/EL TR-03-18, U.S. Army Engineer Research and Development Center, Vicksburg, MS.

Gruber, E., Whytemare, A., 1997. The return of the native? Sidalcea hirtipes in coastal Oregon. In: Kaye, T.N., Liston, A., Love, R.M., Luoma, D.L., Meinke, R.J., Wilson, M.V. (Eds.), Conservation and Management of Native Plants and Fungi. Proceedings of the Oregon Conference on the Conservation and Management of Native Vascular Plants, Bryophytes, and Fungi. Native Plant Society of Oregon, Corvallis, OR, pp. 121-124.

Gutierrez, A.P., Pitcairn, M.J., Ellis, C.K., Carruthers, N., Ghezelbash, R., 2005. Evaluating biological control of yellow starthistle (Centaurea solstitialis) in California: a GIS based supply-demand demographic model. Biological Control 34, 115-131.

Hakim, S.E.A., 1979. Range condition on the Threemile Game Range in Western Montana. M.S. thesis. University of Montana, Missoula, MT.

Hale, L.D., 1970. Biology of Icerya purchasi and its natural enemies in Hawaii. Proceedings of the Hawaiian Entomological Society 20, 533-550.

Hansen, K.L., Ruby, E.G., Thompson, R.L., 1971. Trophic relationships in the waterhyacinth community. Quarterly Journal of the Florida Academy of Science 34 (2), 107-113.

Harley, K.L.S., Kassulke, R.C., Sands, D.P.A., Day, M.D., 1990. Biological control of water lettuce, Pistia stratiotes [Araceae] by Neohydronomus affinis [Coleoptera: Curculionidae]. Entomophaga 35, 363-374. 
Harris, P., 1988. Environmental impact of weed-control insects. BioScience 38 (8), 542-548.

Harris, P., Cranston, R., 1979. An economic evaluation of control methods for diffuse and spotted knapweed in western Canada. Canadian Journal of Plant Science 59, 375-382.

Havill, N.P., Montgomery, M.E., Yu, G., Shiyake, S., Caccone, A., 2006. Mitochondrial DNA from hemlock woolly adelgid (Hemiptera: Adelgidae) suggests cryptic speciation and pinpoints the source of the introduction to eastern North America. Annals of the Entomological Society of America 99, 195-203.

Heard, T.A., Paynter, Q., 2009. Mimosa pigra (Leguminosae). In: Muniappan, R., Reddy, G.V.P., Raman, A. (Eds.), Biological Control of Tropical Weeds using Arthropods. Cambridge University Press, Cambridge, UK, pp. 256-273.

Hein, D.G., Miller, S.D., 1992. Influence of leafy spurge on forage utilization by cattle. Journal of Range Management 45, 405-407.

Hendrickson, D.A., McGaugh, S., 2005. Arundo donax (Carrizo Grande/Giant Cane) in Cuatro Ciénegas. Available from: <http://desertfishes.org/cuatroc/organisms/ non-native/arundo/Arundo.html/ $>$.

Higgins, S.I., Richardson, D.M., Cowling, R.M., Trinder-Smith, T.H., 1999. Predicting the landscape-scale distribution of alien plants and their threat to plant diversity. Conservation Biology 13, 303-313.

Hill, M.G., Newbery, D.M., 1980. The distribution and abundance of the coccid Icerya seychellarum Westw. on Aldabra atoll. Ecological Entomology 5, 115-122.

Hill, M.P., 1999. Biological control of red water fern, Azolla filiculoides Lamarck (Pteridophyta: Azollaceae) in South Africa. In: Olckers, T., Hill, M.P. (Eds.), Biological Control of Weeds in South Africa (1990-1998), vol. 1. African Entomology Memoir, pp. 119-124.

Hill, M.P., McConnachie, A.J., 2009. Azolla filiculoides. In: Muniappan, R., Reddy, G.V.P., Raman, A., Gandhi, V.P. (Eds.), Weed Biological Control with Arthropods in the Tropics. Cambridge University Press, Cambridge, UK, pp. 74-87.

Hill, R.L., Gourlay, A.H., 2002. Host-range testing, introduction and establishment of Cydia succedana (Lepidoptera: Tortricidae) for biological control of gorse, Ulex europaeus L., in New Zealand. Biological Control 25, 173-186.

Hill, R.L., Ireson, J., Sheppard, A.W., Gourlay, A.H., Norambuena, H., Markin, G., Kwong, R., Coombs, E., 2008. A global view of the future for biological control of gorse. In: Julien, M.H., Sforza, R., Bon, M.C., Evans, H.C., Hatcher, P.E., Hinz, H.L., Rector, B.G. (Eds.), XII International Symposium on Biological Control of Weeds. La Grande Motte, France, 22-27, April 2007. CABI, Wallingford, UK, pp. 680686.

Henneman, M.L., Memmott, J., 2001. Infiltration of a Hawaiian community by introduced biological control agents. Science 293, 1314-1316.

Hoffmann, J.H., Moran, V.C., 1991. Biological control of Sesbania punicea (Fabaceae) in South Africa. Agriculture, Ecosystems, and Environment 37, 157-173.

Hoffmann, J.H., Moran, V.C., 1998. The population dynamics of an introduced tree, Sesbania punicea, in South Africa, in response to long-term damage caused by different combinations of three species of biological control agents. Oecologia $114,343-348$

Hoffmann, J.H., Moran, V.C., 2008. Assigning success in biological weed control: what do we really mean? In: Julien, M.H., Sforza, R., Bon, M.C., Evans, H.C., Hatcher, P.E., Hinz, H.L., Rector, B.G. (Eds.), XII International Symposium on Biological Control of Weeds. CAB International, Wallingford, UK, pp. 685690.

Hoffmann, J.H., Moran, V.C., Zeller, D.A., 1998. Long-term population studies and the development of an integrated management programme for control of Opuntia stricta in Kruger National Park, South Africa. Journal of Applied Ecology 35, 156160.

Hofstetter, R.H., 1991. The current status of Melaleuca quinquenervia in southern Florida. In: Center, T.D., Doren, R.F., Hofstetter, R.L., Myers, R.L., Whiteaker, L.D. (Eds.), Proceedings of a Symposium on Exotic Pests Plants. National Park Service, Denver, CO, NPS/NREVER/NRTR-91/06, pp. 159-176.

Hohmann, J., Vasas, A., Günther, G., Máthé, I., Evanice, F., Dombi, G., Jerkovich, G., 1997. Macrocyclic diterpene polyesters of the jatrophane type from Euphorbia esula. Journal of Natural Products 60, 331-335.

Holm, L.G., Weldon, L.W., Blackburn, R.D., 1969. Aquatic weeds. Science 166, 699709.

Holm, L., Doll, J., Holm, E., Pancho, J., Herberger, J., 1997. World Weeds Natural Histories and Distribution. John Wiley \& Sons, Inc., New York. pp. 393-411.

Holmes, P.M., Cowling, R.M., 1997. The effects of invasion by Acacia saligna on the guild structure and regeneration capabilities of South African fynbos shrublands. Journal of Applied Ecology 34, 317-332.

Holmes, P.M., Richardson, D.M., van Wilgen, B.W., Gelderblom, C., 2000. Recovery of South African fynbos vegetation following alien woody plant clearing and fire: implications for restoration. Austral Ecology 25, 631-639.

Holtkamp, R.H., 2002. Impact of the bitou bush tip moth, Comostolopsis germana, on bitou bush in New South Wales. In: Spafford Jacob, H., Dodd, J., Moore, J.H. (Eds.), Proceedings of 13th Australian Weeds. Plant Protection Society of Western Australia, Perth, Australia, pp. 405-406.

Hough-Goldstein, J., Lake, E., Reardon, R., Wu, Y., 2008. Biology and Biological Control of Mile-a-Minute Weed. USDA Forest Service, FHTET-2008-10.

Hough-Goldstein, J., Mayer, M.A., Hudson, W., Robbins, G., Morrison, P., Reardon, R., 2009. Monitored releases of Rhinoncomimus latipes (Coleoptera: Curculionidae), a biological control agent of mile-a-minute weed (Persicaria perfoliata), 20042008. Biological Control 51, 450-457.

Houston, D.R., 1981. Oak decline and mortality. In: Doane, C.C., McManus, M.L. (Eds.), The Gypsy Moth: Research toward Integrated Pest Management. Technical Bulletin No. 1584. US Department of Agriculture, Forest Service, Washington, DC, pp. 217-297.
Howard, T., Sendak, P., Codrescu, C., 2000. Eastern hemlock: a market perspective. In: McManus, K., Shields, K., Souto, D. (Eds.), Proceedings: Symposium on Sustainable Management of Hemlock Ecosystems in Eastern North America. General Technical Report NE-267, Newtown Square, PA: U.S. Department of Agriculture, Forest Service, Northeastern Forest Experiment Station, pp. 161166.

Howarth, F.G., 1991. Environmental impacts of classical biological control. Annual Review of Entomology 36, 485-509.

Howes, F.N., 1979. Plants and Beekeeping. Faber and Faber, London, UK.

Hrusa, G.F., Gaskin, J.F., 2008. The Salsola tragus complex in California (Chenopodiaceae): characterization and status of Salsola australis and the autochthonous allopolyploid Salsola ryanii sp. nov.. Madroño 55 (2), 113-131.

Hudgeons, J.L., Knutson, A.E., Heinz, K.M., DeLoach, C.J., Dudley, T.L., Pattison, R.R. Kiniry, J.R., 2007. Defoliation by introduced Diorhabda elongata leaf beetles (Coleoptera: Chrysomelidae) reduces carbohydrate reserves and regrowth of Tamarix (Tamaricaceae). Biological Control 43, 213-221.

Huffaker, C.B., 1957. Fundamentals of biological control of weeds. Hilgardia 27 101-157.

Huffaker, C.B., Kennett, C.E., 1959. A ten-year study of vegetational changes associated with biological control of Klamath weed. Journal of Range Management 12, 69-82.

Impson, F.A.C., Moran, V.C., Hoffmann, J.H., 2004. Biological control of an alien tree, Acacia cyclops, in South Africa: impact and dispersal of a seed-feeding weevil, Melanterius servulus. Biological Control 29, 375-381.

Impson, F.A.C., Moran, V.C., Kleinjan, C., Hoffman, J.H., Moore, J.A., 2008. Multiplespecies introductions of biological control agents against weeds: look before you leap. In: Julien, M.H., Sforza, R., Bon, M.C., Evans, H.C., Hatcher, P.E., Hinz, H.L., Rector, B.G. (Eds.), Proceedings of the XII International Symposium on Biological Control of Weeds. CABI International, Wallingford, UK, pp. 26-31.

Ireson, J.E., Gourlay, A.H., Kwong, R.M., Holloway, R.J., Chatterton, W.S., 2003. Host specificity, release and establishment of the gorse spider mite, Tetranychus lintearius Dufour (Acarina: Tetranychidae), for the biological control of gorse, Ulex europaeus L. (Fabaceae), in Australia. Biological Control 26, 117-127.

Johnson, R.W., 2004. Environmental impacts of prickly acacia. In: Spies, P., March, N. (Eds.), Prickly Acacia, National Case Studies Manual. The State of Queensland Brisbane, pp. 90-91.

Johnson, S., Threadgold, R., 1999. Report on the monitoring and status of the coccid (Icerya seychellarum) on Aldabra from 1980 to 1999. Unpublished report, Seychelles Islands Foundation.

Joint Nature Conservation Committee, 2009. Available from: <http:/ www.jncc.gov.uk/pdf/OT_StHelena.pdf/> (accessed 23.06.09).

Julien, M.H., 1981. Control of aquatic Alternanthera philoxeroides in Australia: another success for Agasicles hygrophila. In: Delfosse, E.S. (Ed.), Proceedings of the V International Symposium on Biological Control of Weeds, 22-29 July 1980. Brisbane, Australia, pp. 583-588.

Julien, M.H., 1995. The biology of Australian weeds 3. Alternanthera philoxeroides (Mart.) Griseb. In: Groves, R.H., Shepherd, R.C.H., Richardson, R.G. (Eds.), The Biology of Australian Weeds, R.G. and F.J. Richardson, Frankston. Victoria, Australia, pp. 1-12.

Julien, M.H., Griffiths, M.W., 1998. Biological Control of Weeds: A World Catalogue of Agents and their Target Weeds. CABI Publishing, Wallingford, UK.

Julien, M.H., Hill, M.P., Tipping, P.W., 2009. Salvinia molesta D.S. Mitchell (Salviniaceae). In: Muniappan, R., Reddy, G.V.P., Raman, A., Gandhi, V.P. (Eds.) Weed Biological Control with Arthropods in the Tropics. Cambridge University Press, Cambridge, pp. 378-407.

Kato, K., Hijii, N., 1997. Effects of gall formation by Dryocosmus kuriphilus Yasumatsu (Hym., Cynipidae) on the growth of chestnut trees. Journal of Applied Entomology 121, 9-15.

Keeler, M.S., Chew, F.S., 2008. Escaping an evolutionary trap: preference and performance of a native insect on an exotic invasive host. Oecologia 156, 559568.

Kelly, M., Wagner, E., Warner, P., 1998. In: Proceedings California Exotic Pest Plant Council Symposium, vol. 4, pp. 1-70.

Kennedy, T.A., Hobbie, S.E., 2004. Saltcedar (Tamarix ramosissima) invasion alters organic matter dynamics in a desert stream. Freshwater Biology 49, 65-76.

Kennedy, T.A., Finlay, J.C., Hobbie, S.E., 2005. Eradication of invasive Tamarix ramosissima along a desert stream increases native fish density. Ecological Applications 15, 2072-2083.

Killgore, E.M., Sugiyama, L.S., Barreto, R., Gardner, D.E., 1999. Evaluation of Colletrotrichum gloeosporioides for biological control of Miconia calvescens in Hawaii. Plant Disease 83, 964.

Kim, I.K., Delvare, G., La Salle, J., 2004. A new species of Quadrastichus (Hymenoptera: Eulophidae): a gall-inducing pest on Erythrina (Fabaceae). Journal of Hymenoptera Research 13, 243-249.

Kingsbury, J.M., 1964. Poisonous Plants of the United States and Canada. PrenticeHall, Inc., Englewood Cliffs, NJ.

Kobachidze, D., 1967. Der Riesenbastkäfer (Dendroctonus micans Kugel.) in Georgien (UdSSR). Anzeiger für Schädlingskunde 40, 65-68.

Kok, L.T., Salom, S.M., Yan, S., Herrick, N., McAvoy, T.J., 2008. Quarantine evaluation of Eucryptorrhynchus brandti (Harold) (Coleoptera: Curculionidae), a potential biological control agent of tree of heaven, Ailanthus altissima in Virginia, USA. In: Julien, M.H., Sforza, R., Bon, M.C., Evans, H.C., Hatcher, P.E., Hinz, H.L., Rector B.G. (Eds.), Proceedings of the XII International Symposium on Biological Control of Weeds. CAB International, Wallingford, UK, pp. 292-300.

Kriticos, D.J., Stuart, R.M., Ash, J.E., 2004. Exploring interactions between cultural and biological control techniques: modelling bitou bush (Chrysantehmoides 
monilifera spp. rotundata) and a seed fly (Mesoclanis polana). In: Cullen, J.M. Briese, D.T., Kriticos, D.J., Lonsdale, W.M., Morin, L., Scott, J.K. (Eds.), Proceedings of the XI International Symposium on Biological Control of Weeds. CSIRO Entomology, Canberra, Australia, pp. 559-566.

Kufeld, R.C., 1973. Foods eaten by the Rocky Mountain elk. Journal of Range Management 26, 106-113.

Lacey, J.R., Marlow, C.B., Lane, J.R., 1989. Influence of spotted knapweed (Centaurea maculosa) on surface runoff and sediment yield. Weed Technology 3, 627-631.

Lajeunesse, S., Sheley, R., Duncan, C., Lym, R., 1999. Leafy spurge. In: Sheley, R.L., Petroff, J.K. (Eds.), Biology and Management of Noxious Rangeland Weeds. Oregon State University Press, Corvallis, pp. 249-260.

Lamb, A.J., Klaussner, E., 1988. Response of the fynbos shrubs Protea repens and Erica plukenetii to low levels of nitrogen and phosphorus applications. South African Journal of Botany 54, 558-564.

Landis, D.A., Sebolt, D.C., Haas, M.J., Klepinger, M., 2003. Establishment and impact of Galerucella calmariensis L. (Coleoptera: Chrysomelidae) on Lythrum salicaria L. and associated plant communities in Michigan. Biological Control 28, 78-91.

Langeland, K.A., Cherry, H.M., McCormick, C.M., Craddock Burks, K.A. (Eds.), 2008 Identification and Biology of Nonnative Plants in Florida's Natural Areas, second ed. SP257, University of Florida, IFAS Communication Services, Gainesville, Florida, USA.

Leitch, J.A., Leistritz, F.L., Bangsund, D.A., 1994. Economic Effect of Leafy Spurge in the Upper Great Plains: Methods, Models, and Results. Agricultural Economics Report No. 316.

Le Maitre, D.C., van Wilgen, B.W., Chapman, R.A., McKelly, D.H., 1996. Invasive plants and water resources in the Western Caper Province, South Africa: modeling and the consequences of a lack of management. Journal of Applied Ecology 33, 161-172

Leslie, A.J., Spotila, J.R., 2001. Alien plant threatens Nile crocodile (Crocodylus niloticus) breeding in Lake St. Lucia, South Africa. Biological Conservation 98 347-355.

Liabunya, W.W., 2007. Malawi aquatic weeds management at hydro power plants In: Proceedings of Hydro Sri Lanka, The International Conference on Small Hydropower, Kandy, Sri Lanka, 22-24 October 2007.

Lindbloom, A.J., Reese, K.P., Zager, P., 2004. Seasonal habitat use and selection of Chukars in west central Idaho. Western North American Naturalist 64 (3), 338345.

Lindsay, E.A., French, K., 2006. The impact of the weed Chrysanthemoides monilifer ssp. rotundata on coastal leaf litter invertebrates. Biological Invasions 8, 177192

Lockwood, J.A., Hopper, M.F., Marchetti, M., 2006. Invasion Ecology. WileyBlackwell Publications, London.

Long, G.E., 1988. The larch casebearer in the intermountain northwest. In: Berryman, A.A. (Ed.), Dynamics of Forest Insect Populations, Patterns, Causes, Implications. Plenum Press, New York, pp. 233-242.

Longland, W.S., Dudley, T., 2008. Effects of a biological control agent on the use of saltcedar habitat by passerine birds. Great Basin Birds 10, 21-26.

Lovich, J.E., Bainbridge, D., 1999. Anthropogenic degradation of the southern California desert ecosystem and prospects for natural recovery and restoration. Environmental Management 24, 309-326.

Lovich, J.E., DeGouvenain, R.C., 1998. Saltcedar invasion in desert wetlands of the southwestern United States: ecological and political implications. In: Majumdar, S.K. et al. (Eds.), Ecology of Wetlands and Associated Systems Pennsylvania Academy of Science, pp. 447-467.

Louda, S.M., 1998. Population growth of Rhinocyllus conicus (Coleoptera: Curculionidae) on two species of native thistles in prairie. Environmental Entomology 27, 834-841.

Louda, S.M., Potvin, M.A., 1995. Effect of inflorescence-feeding insects on the demography and lifetime fitness of a native plant. Ecology 76, 229-245.

Louda, S.M., Kendall, D., Connor, J., Simberloff, D., 1997. Ecological effects of an insect introduced for the biological control of weeds. Science 277, 1088-1090.

Louda, S.A., Pemberton, R.W., Johnson, M.T., Follett, P.A., 2003. Nontarget effects the Achilles heel of biological control? Retrospective analysis to reduce risk associated with biocontrol introductions. Annual Review of Entomology 48, 365-396.

Lu, W., Montgomery, M.E., 2001. Oviposition, development and feeding of Scymmus (Neopullus) sinuanodulus (Coleoptera: Coccinellidae): a predator of Adelges tsugae (Homoptera: Adelgidae). Annals of the Entomological Society of America $94,64-70$.

Lym, R.G., 2005. Integration of biological control agents with other weed management technologies: successes from the leafy spurge (Euphorbia esula) IPM program. Biological Control 35, 366-375.

Lym, R.G., Kirby, D.R., 1987. Cattle foraging behavior in leafy spurge (Euphorbia esula L.) infested rangeland. Weed Technology $1,314-318$

Lynch, L.D., Thomas, M.B., 2000. Nontarget effects in the biocontrol of insects with insects, nematodes, and microbial agents: the evidence. Biocontrol News and Information $21(4), 117 \mathrm{~N}-130 \mathrm{~N}$.

MacFarlane, D.W., Meyer, S.P., 2005. Characteristics and distribution of potential ash tree hosts for emerald ash borer. Forest Ecology and Management 213, 1524.

Mackey, A.P., 1997. The biology of Australian weeds 29. Acacia nilotica ssp. indica (Benth.) Brenan. Plant Protection Quarterly 12 (1), 7-17.

Maddison, P.A., 1976. Coccoidea from Tarawa, Gilbert Islands. UNDP/FAO Pests and Diseases Surveys in the South Pacific Region. Technical Document No. 29, 6 pp.

Maddox, D.M., 1979. The knapweeds: their economics and biological control in the western states, U.S.A. Rangelands 1 (4), 139-143.
Maerz, J.C., Brown, C.J., Chapin, C.T., Blossey, B., 2005a. Can secondary compounds of an invasive plant affect larval amphibians? Functional Ecology 19, 970-975.

Maerz, J.C., Blossey, B., Nuzzo, V., 2005b. Green frogs show reduced foraging success in habitats invaded by Japanese knotweed. Biodiversity and Conservation 14, 2901-2912.

Magasi, L.P., Syme, P.D., 1984. Gilpinia hercyniae (Hartig), European spruce sawfly (Hymenoptera: Diprionidae). In: Kelleher, J.S., Hulme, M.A. (Eds.), Biological Control Programmes Against Insects and Weeds in Canada 1969-1980. Commonwealth Agricultural Bureaux Franham Royal, UK, pp. 295-297.

Mailu, A.M., Ochiel, G.R.S. Gitonga, W., Njoka, S.W., 1999. Waterhyacinth: an environmental disaster in the Winum Gulf of Lake Victoria and its control. In: Hill, M.P., Julien, M.H., Center, T.D. (Eds.), Proceedings of the First Global Working Group Meeting for the Biological and Integrated Control of Waterhyacinth. Harare, Zimbabwe, 16-19 November 1998, pp. 101-105.

Mailu, A.M., 2001. Preliminary assessment of the social, economic and environmental impacts of waterhyacinth in the Lake Victoria Basin and the status of control. In: Julien, M.H., Hill, M.P., Center, T.D., Ding Jianqing (Eds.), Biological and Integrated control of waterhyacinth, Eichhornia crassipes. Proceedings of the Second Global Working Group Meeting for the Biological and Integrated Control of Waterhyacinth. Beijing, China, 9-12 October 2000. ACIAR Proceedings No. 102, pp. 130-139.

Maldonado, F., 2006. La protección de Chile contra los incendios forestales. Chile Forestal 326, 3-10.

Mallya, G.A., 1999. Waterhyacinth in Tanzania. In: Hill, M.P., Julien, M.H., Center, T.D. (Eds.), Proceedings of the First Global Working Group Meeting for the Biological and Integrated Control of Waterhyacinth. Harare, Zimbabwe, 16-19 November 1998, pp. 25-29.

Manrique, V., Cuda, J.P., Overholt, W.A., Williams, D.A., 2008. Effect of host-plant genotypes on the performance of two candidate biological control agents of Brazilian peppertree in Florida. Biological Control 47, 167-171.

Manser, P.D., 1974. Report to the Government of the Gilbert and Ellis Islands colony on a survey of insect pets of crops. United Nations Development Programme, Food and Agriculture Organisation Programme GEI/70/002. Report TA3246. Multigraph, $35 \mathrm{pp}$

Markin, G.P, Yoshioka, E.R., Brown, R.E., 1995. Gorse. In: Nechols, J.R., Andres, L.A., Beardsley, J.W., Goeden, R.D., Jackson, C.G. (Eds.), Biological Control in the Western United States: Accomplishments and Benefits of Regional Research Project W-84, 1964-1989. University of California, Division of Agriculture and Natural Resources, Oakland, Publication No. 3361, pp. 299-302.

Markin, G.P., Littlefield, J.L., 2008. Biological control of tansy ragwort (Senecio jacobaeae L.) by the cinnabar moth, Tyria jacobaeae (CL) (Lepidoptera: Arctiidae), in the northern Rocky Mountains. In: Julien, M.H., Sforza, R., Bon, M.C., Evans, H.C., Hatcher, P.E., Hinz, H.L., Rector, B.G. (Eds.), Proceedings of the XII International Symposium on Biological Control of Weeds, La Grande Motte, France, 22-227 April, 2007. CAB International, Wallingford, pp. 583-588.

Marler, T.E., Muniappan, R., 2006. Pests of Cycas micronesica leaf, stem, and male reproductive tissues with notes on current threat status. Micronesica 39 (1), 19. Available from: <http://www.uog.edu/up/micronesica/dynamicdata/ assetmanager/images/pdf/marler.pdf/>

Marler, T., Haynes, J., Lindstrom, A., 2006. Cycas micronesica. In: IUCN 2009. IUCN Red List of Threatened Species. Version 2009.1. Available from: <http:// www.iucnredlist.org/details/61316/0/>

Masifwa, W.F., Twongo, T., Denny, P., 2001. The impact of waterhyacinth, Eichhornia crassipes (Mart.) Solms on the abundance and diversity of aquatic macroinvertibrates along the shores of northern Lake Victoria, Uganda. Hydrobiologia 452, 79-88.

Mason, T.J., French, K., 2008. Impacts of a woody invader vary in different vegetation communities. Diversity and Distributions 14, 829-838.

Mbati, G., Neuenschwander, P., 2005. Biological control of three floating water weeds, Eichhornia crassipes, Pistia stratiotes, and Salvinia molesta in the Republic of Congo. Biocontrol 50, 635-645.

McCaffrey, J.P., Campbell, C.L., Andres, L.A., 1995. St. Johnswort. In: Nechols, J.R., Andres, L.A., Beardsley, J.W., Goeden, R.D., Jackson, C.G. (Eds.), Biological Control in the Western United States: Accomplishments and Benefits of Regional Research Project W-84, 1964-1989. University of California, Division of Agriculture and Natural Resources, Oakland, Publication No. 3361, pp. 281-285.

McConnachie, A.J., Hill, M.P., Byrne, M.J., 2004. Field assessment of a frond-feeding weevil, a successful biological control agent of red water fern, Azolla filiculoides, in southern Africa. Biological Control 29, 326-331.

McEvoy, P.B., Cox, C.S., Coombs, E.M., 1991. Successful biological control of ragwort. Ecological Applications 1, 430-442.

McEvoy, P.B., Karacetin, E., Bruck, D.J., 2008. Can a pathogen provide insurance against host shifts by a biological control organism? In: Julien, M.H., Sforza, R., Bon, M.C., Evans, H.C., Hatcher, P.E., Hinz, H.L., Rector, B.G. (Eds.), Proceedings of the XII International Symposium on Biological Control of Weeds, La Grande Motte, France, 22-227 April, 2007. CAB International, Wallingford, pp. 37-42.

McClure, M.S., Cheah, C.A. S.-J., Tigner, T.C., 2000. Is Pseudoscymnus tsugae the solution to the hemlock woolly adelgid problem? An early perspective, In: McManus, K.A. Shields, K.S., Souto, D.R. (Eds.), Proceedings, Symposium on Sustainable Management of Hemlock Ecosystems in Eastern North America, 22-24 June 1999, Durham, NH. USDA Forest Service General Technical Report NE-267, pp. 89-96.

McFadyen, R.E., 1995. Parthenium weed and human health in Queensland. Australian Family Physician 24, 1455-1459.

McFadyen, R.C., 2004. Chromolaena odorata in East Timor: history, extent, and control. In: Day, M.D., McFadyen, R.E. (Eds.), Proceedings of the 6th 
International Workshop on Biological Control and Management of Chromolaena. ACIAR Technical Report \# 55. Canberra, Australia, pp. 8-10.

McGugan, B.M., Coppel, H.C., 1962. Biological control of forest insects - 1910-1958. In: A Review of the Biological Control Attempts Against Insects and Weeds in Canada. Commonwealth Agricultural Bureaux Franham Royal, UK, pp. 35-127.

McKay, F., Oleiro, M., Walsh, G.C., Gandolfo, D., Cuda, J.P., Wheeler, G.S., 2009. Natural enemies of Brazilian peppertree (Schinus terebinthifolius: Anacardiaceae) from Argentina: their possible use for biological control in the USA. Florida Entomologist 92, 292-303.

McManus, M.L., McIntyre, T., 1981. Introduction In: Doane, C.C., McManus, M.L. (Eds.), 1981. The Gypsy Moth: Research toward Integrated Pest Management. Technical Bulletin No. 1584. US Department of Agriculture, Forest Service, Washington, DC, pp. 1-7.

McVea, C., Boyd, C.E., 1975. Effects of waterhyacinth cover on water chemistry, phytoplankton, and fish in ponds. Journal of Environmental Quality 4, 375-378.

Medal, J., Overholt, W., Stansly, P., Roda, A., Osborne, L., Hibbard, K., Gaskalla, R. Burns, E., Chong, J., Sellers, B., Hight, S., Cuda, J., Vitorino, M., Bredow, E., Pedrosa-Macedo, J., Wikler, C., 2008. Establishment, spread, and initial impacts of Gratiana boliviana (Chrysomelidae) on Solanum viarum in Florida. In: Julien, M.H., Sforza, R., Bon, M.C., Evans, H.C., Hatcher, P.E., Hinz, H.L., Rector, B.G. (Eds.), Proceedings XII International Symposium on Biological Control of Weeds. La Grande Motte, France, pp. 591-596.

Medeiros, A.C., Loope, L.L., Conant, P., McElvaney, S., 1997. Status, ecology, and management of the invasive plant Miconia calvescens DC (Melastomataceae) in the Hawaiian Islands. Bishop Museum Occasional Papers, No. 48, pp. 23-36.

Messing, R.H., Wright, M.G., 2006. Biological control of invasive species: solution or pollution? Frontiers in Ecology and the Environment 4, 132-140.

Messing, R.H., Noser, S., Hunkeler, J., 2009. Using host plant relationships to determine the origin of the invasive Erythrina Gall Wasp. Biological Invasions. doi:10.1007/s10530-008-9379-y.

Meyer, J.-Y., 1998. Observation on the reproductive biology of Miconia calvescens DC (Melastomataceae), an alien invasive tree on the island of Tahiti (South Pacific Ocean). Biotropica 30, 609-624.

Meyer, J.-Y., Florence, J., 1996. Tahiti's native flora endangered by the invasion of Miconia calvescens DC (Melastomataceae). Journal of Biogeography 23, 775-781.

Meyer, J.-Y., Taputuarai, R., Killgore, E., 2008. Dissemination and impacts of the fungal pathogen, Colletotrichum gloeosporioides f. sp. miconiae, on the invasive alien tree, Miconia calvescens, in Tahiti (South Pacific). In: Julien, M.H., Sforza, R., Bon, M.C., Evans, H.C., Hatcher, P.E., Hinz, H.L., Rector, B.G. (Eds.), XII International Symposium on Biological Control of Weeds. La Grande Motte, France, 22-27, April 2007. CABI, Wallingford, UK, pp. 594-600.

Meyer, J.-Y., Fourdrigniez, M. Taputuarai, R., 2009. Habitat restoration using a biocontrol agent: the positive effects of the fungal pathogen Colletotrichum gloeosporioides f. sp. miconiae on native plant recruitment in Tahiti (French Polynesia). Abstract of talk at Pacific Science Inter-Congress in Tahiti, February, 2009.

Michigan Department of Natural Resources. Available from: <http:// www.michigan.gov/dnr/>.

Midgley, J.M., Hill, M.P., Villet, M.H., 2006. The effect of waterhyacinth, Eichhornia crassipes (Martius) Solms-Laubach (Pontederiaceae), on benthic biodiversity in two impoundments on the New Year's River, South Africa. African Journal of Aquatic Science 31, 25-30.

Mitchell, D.S., 1978. Aquatic Weeds in Australian Waters. Australian Government Publishing Service, Canberra. 189 pp.

Mitchell, D.S., 1980. The water-fern Salvinia molesta in the Sepik River, Papua New Guinea. Environmental Conservation 7, 115-122.

Mitchell, D.S., 1981. The management of Salvinia molesta in Papua New Guinea. In: Delfosse, E.S. (Ed.), Proceedings of the Fifth International Symposium on Biological Control of Weeds. Commonwealth Scientific and Industrial Research Organization, Melbourne, Australia, pp. 31-34.

Mo, J., Treviño, M., Palmer, W.A., 2000. Establishment and distribution of the rubber vine moth, Euclasta whalleyi Popescu-Gorj and Constantinescu (Lepidoptera: Pyralidae) following its release in Australia. Australian Journal of Entomology 39, 344-350.

Montgomery, M.E., Lyon, S.M., 1996. Natural enemies of adelgids in North America: their prospect for biological control of Adelges tsugae (Homoptera: Adelgidae). In: Salom, S.M., Tigner, T.C., Reardon, R.C. (Eds.), Proceedings, First Hemlock Woolly Adelgid Review, 1995. USDA Forest Service, FHTET 96-10, Charlottesville, Virginia, pp. 89-102.

Montgomery, M.E., Wang, H., Yao, D., Lu, W., Havill, N., Li, G., 2002. Biology of Scymnus ningshanensis (Coleoptera: Coccinellidae): a predator of Adelges tsugae (Homoptera: Adelgidae). In: Onken, B., Reardon, R., Lashomb, J. (Eds.) Proceedings: Hemlock Woolly Adelgid in the Eastern United States Symposium, February 5-7, 2002, East Brunswick, New Jersey. USDA Forest Service and New Jersey Agricultural Experiment Station Publication, pp. 181-188.

Moore, A., Marler, T., Miller, R.H., Muniappan, R., 2005. Biological control of cycad Aulacaspis scale on Guam. The Cycad Newsletter 28 (5), 6-8. http:// www.cycadsg.org/publications/CAS/TCS-Moore-etal.pdf.

Moorhead, K.K., Reddy, K.R., Graetz, D.A., 1988. Waterhyacinth productivity and detritus accumulation. Hydrobiologia 157, 179-185.

Moran, V.C., Hoffmann, J.H., Zimmermann, H.G., 2005. Biological control of invasive alien plants in South Africa: necessity, circumspection, and success. Frontiers of Ecology and the Environment 3, 71-77.

Morin, L., Edwards, P.B., 2006. Selection of biological control agents for bridal creeper - a retrospective review. Australian Journal of Entomology 45, 286290.
Morin, L., Hill, R.L., Matayoshi, S., 1997. Hawaii's successful biological control strategy for mist flower (Ageratina riparia) - can it be transferred to New Zealand? Biocontrol News and Information 18, 77-88.

Morin, L., Batchelor, K.L., Scott, J.K., 2006a. The biology of Australian weeds. Asparagus asparagoides (L.) Druce. Plant Protection Quarterly 21, 46-62.

Morin, L., Neave, M., Batchelor, K.L., Reid, A., 2006b. Biological control: a promising tool for managing bridal creeper in Australia. Plant Protection Quarterly 21, 6977.

Morin, L., Reid, A.M., Sims-Chilton, N.M., Buckley, Y.M., Dhileepan, K., Hastwell, G.T. Nordblom, T.L., Raghu, S., 2009. Review of approaches to evaluate the effectiveness of weed biological control agents. Biological Control 51, 1-15.

Moriya, S., Shiga, M., Adachi, I., 2003. Classical biological control of the chestnut gall wasp in Japan. In: Van Driesche, R.G. (Ed.), Proceedings of the 1st Internationa Symposium on Biological Control of Arthropods, Honolulu, Hawaii, 14-18 January 2002. USDA Forest Service, Morgantown, USA, pp. 407-415.

Muniappan, R., McFadyen, R.E., 2005. Gall-inducing arthropods in the biological control of weeds. In: Raman, A., Schaefer, C.W., Wither, T.M. (Eds.), Biology, Ecology, and Evolution of Gall-inducing Arthropods, vols. 1 and 2. Science Publishers, Inc., Enfield, New Hampshire, USA, pp. 709-730.

Muzika, R.M., Gottschalk, K.W., 1995. Gypsy moth role in forest ecosystems: the good, the bad, and the indifferent. In: Eskew, L.G. (Ed.), Forest Health Through Silviculture: Proceedings of the 1995 National Silviculture Workshop, Mescalero, New Mexico, May 8-11, 1995. Gen. Tech. Rep. RM-GTR-267. U.S Department of Agriculture, Forest Service, Rocky Mountain Forest and Range Experiment Station, Fort Collins, CO, pp. 99-104.

Myers, J.H., Jackson, C., Quinn, H., White, S., Cory, J.S., 2009. Successful biological control of diffuse knapweed, Centaurea diffusa, in British Columbia. Biological Control 50, 66-72.

Nagler, P.L., Glenn, E.P., Didan, K., Osterberg, J., 2008. Wide-area estimates of stand structure and water use of Tamarix spp. on the lower Colorado River: implications for restoration and water management projects. Restoration Ecology 16, 136-145.

Navie, S.C., Panetta, F.D., McFadyen, R.E., Adkins, S.W., 2004. Germinable soil seedbanks of central Queensland rangelands invaded by the exotic weed Parthenium hysterophorus L.. Weed Biology and Management 4 (3), 154-167.

Nechols, J.R., Andres, L.A., Beardsley, J.W., Goeden, R.D., Jackson, C.G., 1995 Biological Control in the Western United States, Accomplishments and Benefits of Regional Project W-84, 1964-1989. University of California Oakland, CA.

Neill, D.A., 1988. Experimental studies on species relationships in Erythrina (Leguminosae: Papilionideae). Annals of Missouri Botanical Garden 75, 886969.

Neira, C., Levin, L.A., Grosholz, E.D., Mendoza, G., 2007. Influence of invasive Spartina growth stages on associated macrofaunal communities. Biological Invasions 9 , 975-993.

Neuenschwander, P., Julien, M.H., Center, T.D., Hill, M.P., 2009. Pistia stratiotes L. (Araceae). In: Muniappan, R., Reddy, G.V., Raman, A. (Eds.), Biological Control of Tropical Weeds Using Arthropods. Cambridge University Press, New York, NY, pp. 332-352.

Newbery, D.M., 1988. Recently monitored trends in the abundance of Icerya seychellarum Westw. (Insecta: Homoptera) on Aldabra Atoll, with suggestions for its biological control. Bulletin Biological Society of Washington 8, 30-39.

Newbery, D.M., Hill, M.G., 1985. Changes in the distribution of the coccid Icerya seychellarum Westw. on Aldabra atoll in relation to vegetation density Atoll Research Bulletin No. 291.

Norambuena, H., 1995. Impact of Apion ulicis Forster (Coleoptera: Apionidae) on gorse Ulex europaeus L. (Fabaceae) in agricultural and silvicultural habitats in Southern Chile. Ph.D. Entomology Department, Washington State University, Pullman, WA

Norambuena, H., Piper, G.L., 2000. Impact of Apion ulicis on Ulex europaeus seed dispersal. Biological Control 17, 267-271.

Norambuena, H., Martinez, G., Carillo, R., Neira, M., 2007. Host specificity and establishment of Tetranychus lintearius (Acari: Tetranychidae) for biological control of gorse (Ulex europaeus). Biological Control 40, 204-212.

Nuzzo, V., 1993. Distribution and spread of the invasive biennial garlic mustard (Alliaria petiolata) in North America. In: McNight, B.N. (Ed.), Biological Pollution: The Control and Impact of Invasive Exotic Species. Indiana Academy of Sciences, Indianapolis, pp. 137-146.

Oehrens, E., 1977. Biological control of the blackberry through the introduction of rust, Phragmidium violaceum. FAO Plant Protection Bulletin 25, 26-28.

Oehrens, E.B., Gonzalez, S.M., 1977. Dispersion, ciclo biologico y daños causados por Phragmidium violaceum (Schultz) Winter en zarzamora (Rubus constrictus Lef. Et M. y R. ulmifolius Schott.) en la zonas centro sur y sur de Chile. Agro Sur 5, 7385.

Opande, G.O., Onyango, J.C., Wagai, S.O., 2004. Lake Victoria: The waterhyacinth (Eichhornia crassipes [Mart.] Solms), its socio-economic effects, control measures and resurgence in the Winam gulf. Limnologica 34, 105-109.

Orwig, D.A., Foster, D.R., 1998. Forest response to the introduced hemlock woolly adelgid in southern New England, USA. Journal of the Torrey Botanical Society 125 (1), 60-73.

Paige, A.R., Lacey, K.L., 2006. Economic impact assessment of Austalian weed biological control. CRC for Australian Weed Management Technical Series No. 10, $150 \mathrm{pp}$.

Palmer, W.A., Lockett, C.J., Senaratne, K.A.D.W., McLennan, A., 2007. The introduction and release of Chiasmia inconspicua and C.assimilis (Lepidoptera: 
Geometridae) for the biological control of Acacia nilotica in Australia. Biological Control 41 (3), 368-378.

Pataki, D.E., Bush, S.E., Gardner, P., Solomon, D.K., Ehleringer, J.R., 2005 Ecohydrology in a Colorado River riparian forest: implications for the decline of Populus fremontii. Ecological Applications 15, 1009-1018.

Pattison, R.R., Mack, R.N., 2007. Potential distribution of the invasive tree Triadica sebifera (Euphorbiaceae) in the United States: evaluating climex predictions with field trials. Global Change Biology 14, 813-826.

Pemberton, R.W., 2000. Predictable risk to native plants in weed biological control. Oecologia 125, 489-494.

Pemberton, R.W., 2003. Potential for biological control for control of the lobate lac scale, Paratachardina lobata lobata (Chamberlin) (Hemiptera: Kerridae). Florida Entomologist 86, 354-361.

Pemberton, R.W., 2009. Proposed field release of Lilioceris sp. near impressa (Fabricius) (Coleoptera: Chrysomelidae), a leaf and bulbil feeder of air potato, Dioscorea bulbifera L. (Dioscoreaceae) in Florida. Petition to release a biological control agent, submitted February 2, 2009. On file at the U.S. Department of Agriculture, Agricultural Research Service Biological Control Documentation Center, National Agricultural Library, Beltsville, Maryland, USA.

Pemberton, R.W., Ferriter, A., 1998. Old World climbing fern (Lygodium microphyllum); a dangerous weed in Florida. American Fern Journal 88, 165175.

Pemberton, R.W., Liu, H., 2007. Control and persistence of native Opuntia on Nevis and St. Kitts 50 years after the introduction of Cactoblastis cactorum. Biological Control 41, 272-282.

Pemberton, R.W., Turner, C.E., 1990. Biological control of Senecio jacobaea in northern California, an enduring success. Entomophaga 35, 71-77.

Petit, J.N., Hoddle, M.S., Grandgirard, J., Roderick, G.K., Davies, N., 2009. Successful spread of a biocontrol agent reveals a biosecurity failure: elucidating long distance invasion pathways for Gonatocerus ashmeadi in French Polynesia. Biocontrol 54, 485-495.

Pitcairn, M.J., Woods, D.M., Popescu, V., 2005. Update on the long-term monitoring of the combined impact of biological control insects on yellow starthistle. In: Woods, D.M. (Ed.), Biological Control Program Annual Summary, 2004. California Department of Food and Agriculture, Plant Health and Pest Prevention Services, Sacramento, CA, pp. 27-30.

Poland, T.M., McCullough, D., 2006. Emerald ash borer: invasion of the urban forest and the threat to North America's ash resource. Journal of Forestry 104, 118124.

Porter, A., 1994. Implications of introduced garlic mustard (Alliaria petiolata) in the habitat of Pieris virginiensis (Pieridae). Journal of the Lepidopterists' Society 48 , 171-172.

Pratt, P.D., Coombs, E.M., Croft, B.A., 2003. Predation by phytoseiid mites on Tetranychus lintearius (Acari: Tetranychidae), an established weed biological control agent of gorse (Ulex europaeus). Biological Control 26, 40-47.

Pratt, P.D., Rayamajhi, M.B., Van, T.K., Center, T.D., 2005. Herbivory alters resource allocation and compensation in the invasive tree Melaleuca quinquenervia. Ecological Entomology 15, 443-462.

Quacchia, A., Moriya, S., Bosio, G., Scapin, I., Alma, A., 2008. Rearing, release and settlement prospect in Italy of Torymus sinensis, the biological control agent of the chestnut gall wasp Dryocosmus kuriphilus. Biocontrol 53, 829-839.

Quin, T.K., Gullan, P.J., 1998. Systematics as a tool for pest management: case studies using scale insects and mites. In: Sixth Australian Applied Entomological Research Conference, Brisbane, 29 September-2 October 1998 pp. $479-488$

Radford, I., Nicholas, D.M., Brown, J.R., 2001. Assessment of the biological control impact of seed predators on the invasive shrub Acacia nilotica (Prickly Acacia) in Australia. Biological Control 20, 261-268.

Rayamajhi, M.B., Purcell, M.F., Van, T.K., Center, T.D., Pratt, P.D., Buckingham, G.R. 2002. Australian paperbark tree (Melaleuca). In: Van Driesche, R.G., Blossey, B. Hoddle, M.S., Lyon, S., Reardon, R. (Eds.), Biological Control of Invasive Plants in the Eastern United States. Forest Health Technology Enterprise Team, Morgantown, West Virginia, pp. 117-130.

Rayamajhi, M.B., Van, T.K., Pratt, P.D., 2007. Melaleuca quinquenervia dominated forests in Florida: analyses of natural-enemy impacts on stand dynamics. Plant Ecology 192, 119-132.

Rayamajhi, M.B., Pratt, P.D., Van, T.K., Center, T.D., 2008. Aboveground biomass of an invasive tree melaleuca (Melaleuca quinquenervia), before and after herbivory by adventive and introduced natural enemies: a temporal case study in Florida. Weed Science 56, 451-456.

Rayamajhi, M.B., Pratt, P.D., Van, T.K., Center, T.D., 2009. Decline in exotic tree density facilitates increased plant diversity: the experience from Melaleuca quinquenervia invaded wetlands. Wetlands Ecology and Management 17, 455467.

Reckendorf, F., Leach, D., Baum, R., Carbon, J., 1985. Stabilization of sand dunes in Oregon. Agricultural History 59, 260-268.

Reyes, O., Casal, M., Rego, F.C., 2009. Resprouting ability of six Atlantic shrub species. Folia Geobot 44, 19-29.

Richard, A., Lankau1, R.A., Rogers, W.E., Siemann, E., 2004. Constraints on the utilisation of the invasive Chinese tallow tree Sapium sebiferum by generalist native herbivores in coastal prairies. Ecological Entomology 29, 66-75.

Richardson, D.M., van Wilgen, B.W., Higgins, S.I., Trinder-Smith, T.H., Cowling, R.M. McKelly, D.H., 1996. Current and future threats to biodiversity on the Cape Peninsula. Biodiversity and Conservation 5, 607-647.

Richardson, D.M., Macdonald, I.A.W., Hoffmann, J.H., Henderson, L., 1997. Alien plant invasion. In: Cowling, R.M., Richardson, D.M., Pierce, S.M. (Eds.)
Vegetation of Southern Africa. Cambridge University Press, Cambridge, UK, pp. 535-570.

Roberts, P.D., Pullin, A.S., 2008. The effectiveness of management interventions for the control of Spartina species: a systematic review and meta-analysis. Aquatic Conservation: Marine and Freshwater Ecosystems 18, 592-618.

Robles, M., Wang, N., Kim, R., Choi, B.H., 1997. Cytotoxic effects of repin, a principal sesquiterpene lactone of Russian knapweed. Journal of Neuroscience Research 47, 90-97.

Roché, C.T., Roché Jr., B.F., 1988. Distribution and amount of four knapweed (Centaurea L.) species in eastern Washington. Northwest Science 62, 242253.

Room, P.M., Thomas, P.A., 1985. Nitrogen and establishment of a beetle for biological control of the floating weed salvinia in Papua New Guinea. Journal of Applied Ecology 22, 139-156.

Room, P.M., Harley, K.L.S., Forno, I.W., Sands, D.P.A., 1981. Successful biological control of the floating weed salvinia. Nature 294, 78-80.

Roque-Albelo, L., 2003. Population decline of Galapagos endemic Lepidoptera on Volcan Alcedo (Isabela island, Galápagos Islands, Ecuador): an effect of the introduction of the cottony cushion scale? Bulletin de l'Institut Royal des Sciences Naturelles de Belgique, Entomologie 73, 1-4.

Rørslett, B., 2006. Aquatic weed problems in a hydroelectric river: the R. Otra, Norway. Regulated Rivers: Research and Development 2, 25-37.

Rose, K.E., Louda, S.M., Rees, M., 2005. Demographic and evolutionary impacts of native and invasive herbivores on Cirsium canescens. Ecology 86, 453-465.

Ross, R.M., Bennett, R.M., Snyder, C.D., Young, J.A., Smith, D.R., Lemarie, D.P., 2003. Influence of eastern hemlock (Tsuga canadensis L.) on fish community structure and function in headwater streams of the Delaware River basin. Ecology of Freshwater Fish 11, 1-6.

Royle, D.D., Lathrop, R.G., 1997. Monitoring hemlock health in New Jersey using Landsat TM data and change detection techniques. Forest Science 43 (3), 327335.

Ryan, R.B., 1990. Evaluation of biological control: introduced parasites of larch casebearer (Lepidoptera: Coleophoridae) in Oregon. Environmental Entomology 19, 1873-1881.

Sainty, G., McCorkelle, G., Julien, M., 1998. Control and spread of alligator weed (Alternanthera philoxeroides (Mart.) Griseb.), in Australia: lesson for other regions. Wetlands Ecological Management 5, 195-201.

Samuel, L.W., Kirby, D.R., Norland, J.E., Anderson, G.L., 2008. Leafy spurge suppression by flea beetles in the Little Missouri drainage basin, USA. Rangeland Ecology and Management 61, 437-443.

Sands, D.P.A., Lukins, R.G., Snowball, G.J., 1986. Agents introduced into Australia for biological control of Gascardia destructor (Newstead) (Hemiptera: Coccidae). Journal of the Australian Entomological Society 25, 51-59.

Sands, D.P.A., Vickers, R.A., Brancatini, V. and Fahey, O., 1999. Control of breadfruit mealybug in the Pacific. P. 73 in Report of Research, July 1997-July 1999 (Malcolm Robertson ed), CSIRO Division of Entomology, Canberra.

Schmidt, W.C., Shearer, R.C., Roe, A.L., 1976. Ecology and silviculture of western larch forests. Technical Bulletin No. 1520, USDA Forest Service, 97 pp.

Schooler, S.S. 1998. Biological Control of Purple Loosestrife Lythrum salicaria By Two chrysomelid beetles Galerucella pusilla and G. calmariensis. Masters Thesis, Oregon State University, Corvallis, Oregon, USA.

Schooler, S.S., McEvoy, P.B., Coombs, E.M., 2006. Negative per capita impacts of purple loosestrife and reed canary grass on plant diversity of wetland communities. Diversity and Distributions 12, 351-363.

Schooler, S.S., McEvoy, P.B., Hammond, P., Coombs, E.M., 2009. Negative per capita effects of two invasive plants, Lythrum salicaria and Phalaris arundinaceae, on the moth diversity of wetland communities. Bulletin of Entomological Research 99, 229-243.

Schroer, S., Pemberton, R.W., 2007. Host acceptance tests of parasitoids of the Indian Paratachardina lobata on the invasive lobate lac scale in Florida. Florida Entomologist 90, 545-552.

Schroer, S., Pemberton, R.W., Cook, L.G., Kondo, T., Gullan, P.J., 2008. The genetic diversity, relationships, and potential for biological control of the lobate lac scale, Paratachardina pseudolobata Kondo and Gullan (Hemiptera: Coccideae: Kerridae), a pest in Florida, the Bahamas and Christmas Island. Biological Control 46, 256-266.

Schweitzer, D.F., Minno, M.C., Wagner, D.L., 2010. Rare, declining, or poorly known butterflies and moths (Lepidoptera) of forests and woodlands in the eastern United States. USFS Technology Transfer Bulletin FHTET-2010-xx, in press.

Seastedt, T.R., Knochel, D.G., Garmoe, M., Shosky, S.A., 2007. Interactions and effects of multiple biological control insects on diffuse and spotted knapweed in the Front Range of Colorado. Biological Control 42, 345-354.

Seawright, E.K., Rister, M.E., Lacewell, R.D., McCorkle, D.A., Sturdivant, A.W., Yang, C., Goolsby, J.A., 2009. Economic implications for the biological control of Arundo donax in the Rio Grande Basin. Southwestern Entomologist 34, 377-394.

Seixas, C.D.S., Barreto, R.W., Freitas, L.G., Maffia, L.A., Monteiro, F.T., 2004 Ditylenchus drepanocercus (Nematoda), a potential biological control agent for Miconia calvescens (Melastomataceae): host-specificity and epidemiology. Biological Control 31, 29-37.

Serbesoff-King, K., 2003. Melaleuca in Florida: a literature review on the taxonomy, distribution, biology, ecology, economic importance, and control measures. Journal of Aquatic Plant Management 41, 98-112.

Shafroth, P.B., Cleverly, J.R., Dudley, T.L., Taylor, J.P., Van Riper, C., Weeks, E.P., Stuart, J.N., 2005. Control of Tamarix in the western United States: implications for water salvage, wildlife use, and riparian restoration. Environmental Management 35, 231-246. 
Sharratt, B.S., Lauer, D., 2006. Particulate matter concentration and air quality affected by windblown dust in the Columbia Plateau. Journal of Environmental Quality 35, 2011-2016.

Sharratt, B., Feng, G., Wendling, L., 2007. Loss of soil and PM10 from agricultural fields associated with high winds on the Columbia Plateau. Earth Surface Processes and Landforms 32, 621-630.

Shaw, R.H., Bryner, S., Tanner, R., 2009. The life history and host range of the Japanese knotweed psyllid, Aphalara itadori Shinji: potentially the first classical biological weed control agent for the European Union. Biological Control 49, 105-113.

Sheley, R.L., Larson, L.L., Jacobs, J.J., 1999. Yellow starthistle. In: Sheley, R.L., Petroff, J.K. (Eds.), Biology and Management of Noxious Rangeland Weeds. Oregon State University Press, Corvallis, pp. 408-416.

Sher, A.A., Marshall, D.L., Taylor, J.P., 2002. Establishment patterns of native Populus and Salix in the presence of invasive nonnative Tamarix. Ecological Applications 12, 760-772.

Simberloff, D., Schmitz, D.C., Brown, T.C., 1997. Strangers in Paradise, Impact and Management of Non-indigenous Species in Florida. Island Press, Washington, DC.

Simberloff, D., Stiling, P., 1996. Risks of species introduced for biological control. Biological Conservation 78, 185-192.

Skinner, K.M., Smith, L., Rice, P., 2000. Using noxious weed lists to prioritize targets for developing weed management strategies, including biological control programs. Weed Science 48, 640-644.

Smith, D., Beattie, G.A.C., Broadley, R. (Eds.), 1997. Citrus Pests and their Natural Enemies. Integrated Pest Management in Australia. Queensland Department of Primary Industries, Information Series Q 197030, $272 \mathrm{pp}$

Smith, L., 2004. Impact of biological control agents on diffuse knapweed in central Montana. In: Cullen, J.M., Briese, D.T., Kriticos, D.J., Lonsdale, W.M., Morin, L. Scott, J.K. (Eds.), Proceedings of the XI International Symposium on Biological Control of Weeds. CSIRO Entomology, Canberra, Australia, pp. 589-593.

Smith, L., 2005. Host plant specificity and potential impact of Aceria salsolae (Acari: Eriophyidae), an agent proposed for biological control of Russian thistle (Salsola tragus). Biological Control 34, 83-92.

Smith, L., 2007. Physiological host range of Ceratapion basicorne, a prospective biological control agent of Centaurea solstitialis (Asteraceae). Biological Control $41,120-133$.

Smith, L., Cristofaro, M., de Lillo, E., Monfreda, R., Paolini, A., 2009. Field assessment of host plant specificity and potential effectiveness of a prospective biological control agent, Aceria salsolae, of Russian thistle, Salsola tragus. Biological Control 48, 237-243.

Smith, N.J., Smith, D., 2000. Studies on the flatid Jamella australiae Kirkaldy causing dieback in Pandanus tectorius var. pedunculatus (A.Br.) Domin on the Sunshine and Gold Coasts in Southeast Queensland. General and Applied Entomology 29, 11-20.

Snowball, G.J., 1969. Prospects for biological control of white wax scale. Journal of the Entomological Society of Australia (N.S.W.) 5, 23-33.

Snyder, C.D., Young, J.A., Lemarié, D.P., Smith, D.R., 2002. Influence of eastern hemlock (Tsuga canadensis) forests on aquatic invertebrate assemblages in headwater streams. Canadian Journal of Fisheries and Aquatic Science 59, 262275.

Sorensen, B., Jusaitis, M., 1995. The impact of bridal creeper on an endangered orchid. In: Cooke, D., Choate, J. (Eds.), Weeds of Conservation Concern: Seminar and Workshop Papers. Department of Environmental and Natural Resources and Animal and Plant Control Commission, Adelaide, Australia, pp. 27-31.

Spoon, C.W., Bowles, H.R., Kulla, A., 1983. Noxious weeds on the Lolo National Forest. A situation analysis staff paper. U.S. Department of Agriculture Forest Service, Northern Region, Missoula, MT.

St. Helena National Trust 2009. Available from: <http://www.nationaltrust.org.sh/ millennium_forest.html/> (accessed 23.06.09).

Stalling, D. 1998. Weeds: an exotic invasion of elk country. Bugle - Journal of Elk and the Hunt (July/Aug 1998), 16-27.

Stock, W.D., Wienand, K.T., Baker, A.C., 1995. Impacts of invading $\mathrm{N}_{2}$-fixing Acacia species on patterns of nutrient cycling in two Cape ecosystems: evidence from soil incubation studies and ${ }^{15} \mathrm{~N}$ natural abundance values. Oecologia 101, 375382

Story, J.M., Good, W.R., White, L.J., Smith, L., 2000. Effects of the interaction of the biocontrol agent, Agapeta zoegana L. (Lepidoptera: Cochylidae), and grass competition on spotted knapweed. Biological Control 17, 182-190.

Story, J.M., Callan, N.W., Corn, J.G., White, L.J., 2006. Decline of spotted knapweed density at two sites in western Montana with large populations of the introduced root weevil, Cyphocleonus achates (Fahraeus). Biological Control 38, 227-232.

Story, J.M., Smith, L., Corn, J.G., White, L.J., 2008. Influence of seed head - attacking biological control agents on spotted knapweed reproductive potential in western Montana over a 30-year period. Environmental Entomology 37, 510-519.

Strang, R.M., Lindsay, K.M., Price, R.S., 1979. Knapweeds: British Columbia's undesirable aliens. Rangelands 1 (4), 141-143.

Stromberg, J.C., Fry, J., Patten, D.T., 1997. Marsh development after large floods in an alluvial, arid-land river. Wetlands 17, 292-300.

Suttle, K.B., Hoddle, M.S., 2006. Engineering enemy free space: an invasive pest that kills its predators. Biological Invasions 8, 639-649.

Swarbrick, J.T., Willson, B.W., Hannan-Jones, M.A., 1995. The biology of Australian weeds 25. Lantana camara L.. Plant Protection Quarterly 10, 82-95.

Tang, W., Yang, S.-L., Vatcharakorn, P., 1997. Cycads of Thailand. Nong Nooch Tropical Garden and the Cycad Conservation Company, Bangkok, Thailand.
Thomas, J., Leys, A., 2002. Strategic management of bitou bush (Chrysanthemoides monilifera ssp, rotundata (L.) T. Norl.). In: Spafford Jacob, H., Dodd, J., Moore, J.H. (Eds.), Proceedings of 13th Australian Weeds. Plant Protection Society of Western Australia, Perth, Australia, pp. 586-590.

Thomas, J.R., Packham, D.J.L., Hilton, G.M., 1992. Ecology of Woodlands and Forests. Kluwer Academic Publishers, Dordrecht, NL.

Thomas, P.A., Room, P.M., 1986a. Successful control of the floating weed Salvinia molesta in Papua New Guinea: a useful biological invasion neutralizes a disastrous one. Environmental Conservation 13, 242-248.

Thomas, P.A., Room, P.M., 1986b. Taxonomy and control of Salvinia molesta. Nature 320, 581-584.

Tipping, P.W., Martin, M.R., Pratt, P.D., Center, T.D., Rayamajhi, M.B., 2008 Suppression of growth and reproduction of an exotic invasive tree by two introduced insects. Biological Control 44, 235-241.

Tipping, P.W., Martin, M.R., Nimmo, K.R., Pierce, R.M., Smart, M.D., White, E. Madeira, P.T., Center, T.D., 2009. Invasion of a West Everglades wetland by Melaleuca quinquenervia countered by classical biological control. Biological Control 48, 73-78.

Toft, J.D., Simenstad, C.A., Cordell, J.R., Grimaldo, L.F., 2003. The effects of introduced waterhyacinth on habitat structure, invertebrate assemblages, and fish diets. Estuaries and Coasts 26, 746-758.

Tomley, A.J., 1995. The biology of Australian weeds 26. Cryptostegia grandiflora R. Br.. Plant Protection Quarterly 10 (4), 122-130.

Towers, G.H.N., Subba Rao, P.V., 1992. Impact of the pan-tropical weed, Parthenium hysterophorus L. on human affairs. In: Richardson, R.G. (Ed.), Proceedings of the First International Weed Control Congress, vol. 2. Weed Science Society of Victoria, Melbourne, pp. 134-138.

Tracy, J.L., Robbins, T.O., 2009. Taxonomic revision and biogeography of the Tamarix-feeding Diorhabda elongata (Brullé, 1832) species group (Coleoptera: Chrysomelidae: Galerucinae: Galerucini) and analysis of their potential in biological control of Tamarisk. Zootaxa 2101, 1-152.

Trammell, M.A., Butler, J.L., 1995. Effects of exotic plants on native ungulate use of habitat. Journal of Wildlife Management 59, 808-816.

Trujillo, E.E., 2005. History and success of plant pathogens for biological control of introduced weeds in Hawaii. Biological Control 33, 113-122.

Turner, C.E., McEvoy, P.B., 1995. Tansy ragwort. In: Nechols, J.R., Andres, L.A. Beardsley, J.W., Goeden, R.D., Jackson, C.G. (Eds.), Biological Control in the Western United States: Accomplishments and Benefits of Regional Research Project W-84, 1964-1989. University of California, Division of Agriculture and Natural Resources, Oakland. Publication No. 3361, pp. 264-269.

Turner, P.J., Scott, J.K., Spafford Jacob, H., 2006. Barrier to restoration: the decomposition rate of bridal creeper's root system. In: Preston, C., Watts, J.H., Crossman, N.D. (Eds.), Proceedings of the 15th Australian Weeds Conference. Weed Management Society of South Australia, Adelaide, Australia, pp. 827-830.

Turner, P.J., Scott, J.K., Spafford, H., 2008a. The ecological barriers to the recovery of bridal creeper (Asparagus asparagoides (L.) Druce) infested sites: impacts on vegetation and the potential increase in other exotic species. Austral Ecology 33, 713-722.

Turner, P.J., Scott, J.K., Spafford, H., 2008b. Implications of successful biological control of bridal creeper Asparagus asparagoides (L) Druce in south-west Australia. In: van Klinken, R.D., Osten, V.A., Panetta, F.D., Scanlan, J.C. (Eds.), Proceedings of the 16th Australian Weeds Conference. Queensland Weed Society, Brisbane, Australia, pp. 390-392.

Ultsch, G., 1973. The effects of waterhyacinth (Eichhornia crassipes) on the microenvironment of aquatic communities. Archives of Hydrobiology 72 , 460-473.

USDA APHIS, 2007. The proposed release of three parasitoids for the biological control of the emerald ash borer (Agrilus planipennis) in the continental United States: environmental assessment. Federal Register 72, 28947-28948. Docket No. APHIS-2007-0060.

USDA Forest Service website. Available from: <http://na.fs.fed.us/fhp/gm/ defoliation/index.shtm/>, statistics on acres of defoliation by gypsy moth.

Valentine, L.E., Roberts, B., Schwarzkopf, L., 2007. Mechanisms driving avoidance of non-native plants by lizards. Journal of Applied Ecology 44, 228-237.

van der Westhuizen, L., 2006. The evaluation of Phenrica sp. 2 (Coleoptera: Chrysomelidae: Alticinae), as a possible biological control agent for Madeira vine, Andredera cordifolia (Ten.) Steenis in South Africa. M.S. Department Zoology and Entomology, Rhodes University, Grahamstown, South Africa.

Van Driesche, R.G., 1994. Classical biological control of environmental pests. Florida Entomologist 77, 20-33.

Van Driesche, R.G., Bellows Jr., T.S., 1996. Biological Control. Chapman and Hall, New York. 539 pp.

Van Driesche, R.G., Healy, S., Reardon, R., 1996. Biological control of arthropod pests of the northeastern and north central forests in the United States: a review and recommendations. FHTET-96-19, US Department of Agriculture, Forest Service, Morgantown, West Virginia.

Van Driesche, R.G., Blossey, B., Hoddle, M., Lyon, S., Reardon, R., 2002. Biological control of invasive plants in the eastern United State. FHTET-2002-04, USDA Forest Service, Morgantown, West Virginia.

Van Driesche, R., Hoddle, M., Center, T., 2008. Control of Pests and Weeds by Natural Enemies: An Introduction to Biological Control. Blackwell, Malden, MA, USA. $473 \mathrm{pp}$.

van Klinken, R.D., Graham, J., Flack, L., 2006. The demography of exotic, invasive fire-tolerant mesquite (Prosopis) in Australia and the implications for ecosystem impacts and management. Biological Invasions 8, 727-741. 
van Klinken, R.D., Campbell, S., 2009. Australian weeds series: Prosopis species. In: Panetta, F.D. (Ed.), Australian Weeds Series, vol. 3, pp. 238-273.

van Lenteren, J.C., Bale, J.S., Bigler, F., Hokkanen, H.M.T., Loomans, A.J.M., 2006. Assessing risks of releasing exotic biological control agents of arthropod pests. Annual Review of Entomology 51, 609-634.

van Wilgen, B.W., Bond, W.J., Richardson, D.M., 1992. Ecosystem management. In: Cowling, R.M. (Ed.), The Ecology of Fynbos. Nutrients, Fire and Diversity. Oxford University Press, Cape Town, South Africa, pp. 345-371.

van Wilgen, B.W., Reyers, B., Le Maitre, D.C., Richardson, D.M., Schonegevel, L., 2008. A biome-scale assessment of the impact of invasive alien plants on ecosystems services in South Africa. Journal of Environmental Management 89, 336-349.

Versfeld, D.B., van Wilgen, B.W., 1986. Impacts of woody aliens on ecosystem properties. In: Macdonald, I.A.W., Kruger, F.J., Ferrar, A.A. (Eds.), The Ecology and Control of Biological Invasions in South Africa. Oxford University Press, Cape Town, South Africa, pp. 239-246.

Vivian-Smith, G., Lawson, B.E., Turnbull, I., Downey, P.O., 2007. The biology of Australian weeds. 46. Anredera cordifolia (Ten.) Steenis. Plant Protection Quarterly 22, 2-10.

Vogler, W., Lindsay, A., 2002. The impact of the rust fungus Maravalia crytostegiae on three rubber vine (Cryptostegia grandiflora) populations in tropical Queensland. In: Jacob, H.S., Dodd, J., Moore, J.H. (Eds.), 13th Australian Weeds Conference "Threats Now and Forever?", Perth, Western Australia, 8-13 September, 2002. Plant Protection Society of Western Australia, Victoria Park, pp. 180-182.

Voigt, G.K., Mergen, F., 1962. Seasonal variation in the toxicity of Ailanthus leaves to pine seedlings. Botanical Gazette 123, 262-265.

Volin, J.C., Lott, M.S., Muss, J.D., Owen, D., 2004. Predicting rapid invasion of the Florida Everglades by Old World Climbing Fern (Lygodium microphyllum) Diversity and Distributions 10, 439-446.

Wade, D.D., 1981. Some Melaleuca-fire relationships, including recommendations for home-site protections. In: Geiger, R.K. (Ed.), Proceedings of the Melaleuca Symposium. Florida Department of Agriculture and Consumer Services, Division of Forestry, Tallahassee, Florida.

Wagner, D.L., 2007. Emerald ash borer threatens ash-feeding Lepidoptera. Newsletter of the Lepidopterists Society 49, 10-11.

Walden, D., van Dam, R., Finlayson, M., Storrs, M., Lowry, J., Kriticos, D., 2004. A risk assessment of the tropical wetland weed Mimosa pigra in Northern Australia. In: Julien, M., Flanagan, G., Heard, T., Hennecke, B., Paynter, O., Wilson, C. (Eds.), Research and Management of Mimosa pigra. CSIRO Entomology, Canberra Australia, pp. 11-21.

Walton, C., 2005. Reclaiming Lost Provinces: A Century of Weed Biological Contro in Queensland. Queensland Department of Natural Resources and Mines, Brisbane, Australia. 104 pp

Wang, Y., Ding, J., Wheeler, G., Purcell, M., Zhang, G., 2009. Heterapoderopsis bicallosicollis (Coleoptera: Attelabidae), a potential biological control agent for Chinese tallow (Triadica sebifera). Environmental Entomology 38, 1135-1144.

Waterhouse, D.F., 1993. Biological Control Pacific Prospects - Supplement 2. Australian Centre for International Agricultural Research, Canberra.

Waterhouse, D.F., Sands, D.P.A., 2001. Classical Biological Control of Arthropods in Australia. Australian Centre for International Agricultural Research, Canberra Australia.

Watson, A.K., Renney, A.J., 1974. The biology of Canadian weeds, 6. Centaurea diffusa and C. maculosa. Canadian Journal of Plant Science 54, 687-701.

Watson, G.W., Voegtlin, D.J., Murphy, S.T., Foottit, R.G., 1999. Biogeography of the Cinara cupressi complex (Hemiptera: Aphididae) on Cupressaceae, with description of a pest species introduced into Africa. Bulletin of Entomological Research 89, 271-283.

Webb, F.E., Quednau, F.W., 1971. Coleophora laricella (Hübner), larch casebearer (Lepidoptera: Coleophoridae). In: Kelleher, J.S., Hulme, M.A. (Eds.), Biological Control Programmes Against Insects and Weeds in Canada 1959-1968. Commonwealth Institute of Biological Control, Technical Communication No. 4, Commonwealth Agricultural Bureaux, Farnham Royal, UK, pp. 131-136.

Webb, R.E., White, G.B., Thorpe, K.W., Talley, S.E., 1999. Quantitative analysis of a pathogen-induced premature collapse of a "leading edge" gypsy moth (Lepidoptera: Lymantriidae) population in Virginia. Journal of Entomological Science 34, 84-100.

Weise, C., Amalin, D., Coe, R., Mannion, C., 2005. Effects of the parasitic wasp Coccobius fulvus on cycad aulacaspis scale, Aulacaspis yasumatsui, at
Montgomery Botanical Center, Miami, Florida. Proceedings of the Florida State Horticultural Society 118, 319-321.

Wheeler, G.S., Pemberton, R.W., Raz, L., 2007. A biological control feasibility study of the invasive weed - air potato, Dioscorea bulbifera L. (Dioscoreaceae); an effort to increase biological control transparency and safety. Natural Areas Journal 27, 269-279.

Wilcox, D.D., Call, C.A., Ramsey, D., Bagley, C., 1996. Ecological amplitude and invasion of diffuse knapweed (Centaurea diffusa) at Yakima Training Center, Washington. In: Proceedings of the Society for Range Management Meeting, February 10-15, 1996. Wichita, Kansas, p. 84 (Abstract only).

Williams, J., West, C., 2000. Environmental weeds in Australia and New Zealand: issues and approaches to management. Austral Ecology 25, 425-444.

Willis, A.J., McKay, R., Vranjic, J.A., Kilby, M.J., Groves, R.H., 2003. Comparative seed ecology of the endangered shrub, Pimelea spicata and a threatening weed, bridal creeper: smoke, heat and other fire-related germination cues. Ecological Management and Restoration 4, 55-65.

Wilson, J.R.U., Ajuonu, O., Center, T.D., Hill, M.P., Julien, M.H., Katagira, F.F., Neuenschwander, P., Njoka, S.W., Ogwang, J., Reeder, R.H., Van, T., 2007. The decline of waterhyacinth on Lake Victoria was due to biological control by Neochetina spp. Aquatic Botany 87, 90-93.

Winn, M.F., Araman, P.A., 2005. Study of the Utilization Options for Dead and Dying Eastern Hemlock in the Southern Appalachians. In: Proceedings, Third Symposium on Hemlock Woolly Adelgid in the Eastern United States, pp. 360-363.

Wood, A.R., Morris, M.J., 2007. Impact of the gall-forming rust fungus Uromycladium tepperianum on the invasive tree Acacia saligna in South Africa: 15 years of monitoring. Biological Control 41, 68-77.

Woods, D.M., Bruckart III., W.L., Pitcairn, M., Popescu, V., O’Brien, J., 2009. Susceptibility of yellow starthistle to Puccinia jaceae var. solstitialis and greenhouse production of inoculum for classical biological control programs. Biological Control 50, 275-280.

Wu, Y., Reardon, R.C., Ding, J., 2002. Mile-a-minute weed. In: Van Driesche, R., Lyon, S., Blossey, B., Hoddle, M., Reardon, R. (Eds.), Biological Control of Invasive Plants in the Eastern United States. USDA Forest Service Publication FHTET-2002-04, pp. 331-341.

Yang, M.M., Tung, G.S., LaSalle, J., Wu, M.L., 2004. Outbreak of Erythrina gall wasp (Hymenoptera: Eulophidae) on Erythrina spp. (Fabaceae) in Taiwan. Plant Protection Bulletin 46, 391-396.

Yelenik, S.G., Stock, W.D., Richardson, D.M., 2004. Ecosystem level impacts of invasive Acacia saligna in the South African fynbos. Restoration Ecology 12, 44-51.

Young, F.L., 2006. Russian thistle (Salsola spp.) biology and management. In: Preston, C., Watts, J.H., Crossman, N.D. (Eds.), 15th Australian Weeds Conference, Papers and Proceedings, Adelaide, South Australia, 24-28 September, 2006: Managing Weeds in a Changing Climate. Weed Management Society of South Australia, Victoria, Australia, pp. 145-147.

Zachariades, C., Day, M., Muniappan, R., Reddy, G.V.P., 2009. Chromolaena odorata (L.). King and Robinson (Asteraceae). In: Muniappan, R., Reddy, G.V.P. Raman, A (Eds.), Biological Control of Tropical Weeds Using Arthropods. Cambridge University Press, Cambridge, UK, pp. 130-162.

Zavaleta, E., 2000. The economic value of controlling an invasive shrub. Ambio 29, 462-467.

Zeck, E.H., 1932. Investigations on two white wax scales (Ceroplastes) as pests in Australia. Agricultural Gazette, New South Wales 43, 611-616.

Zeiger, C.F., 1962. Hyacinth - obstruction to navigation. Hyacinth Control Journal 1, 16-17.

Zilahi-Balogh, G.M.G., Kok, L.T., Salom, S.M., 2002. Host specificity of Laricobius nigrinus (Coleoptera: Derodontidae), a potential biological control agent of the hemlock woolly adelgid, Adelges tsugae Annand (Homoptera: Adelgidae). Biological Control 24, 192-198.

Zilahi-Balogh, G.M.G., Humble, L.M., Lamb, A.B., Salom, S.M., Kok, L.T., 2003. Seasonal abundance and synchrony between Laricobius nigrinus (Coleoptera: Derodontidae) and its prey, the hemlock woolly adelgid (Hemiptera: Adelgidae). The Canadian Entomologist 135, 103-115.

Zimmermann, H.G., Moran, V.C., Hoffmann, J.H., 2009. Invasive cactus species (Cactaceae). In: Muniappan, R., Reddy, G.V., Raman, A.A. (Eds.), Biological Control of Tropical Weeds Using Arthropods. Cambridge University Press, Cambridge, UK, pp. 108-129. 